Energy

Information

Administration

\title{
Directory of Energy Information Administration Models 1995
}

July 1995

$$
\begin{aligned}
& \text { DEOENEO } \\
& \text { JUL } 24995 \\
& \text { OSTI }
\end{aligned}
$$


This directory was prepared by Herbert Miller under the general direction of Jay Casselberry, Team Leader, Standards and Services Division, Office of Statistical Standards, Energy Information Administration (EIA).

Questions concerning the general contents of this directory should be referred to Herbert Miller on (202) 254-5346. Questions relating to the uses of specific models may be directed to the individual model contacts listed in the model descriptions.

This publication and other Energy Information Administration (EIA) publications may be purchased from the Superintendent of Documents, U.S. Government Printing Office.

All telephone orders should be directed to:

U.S. Government Printing Office

McPherson Square Bookstore

1510 H Street, N.W.

Washington, DC 20005

(202) 653-2050

FAX (202) 376-5055

9 a.m. to $4: 30$ p.m., eastern time, M-F
Superintendent of Documents U.S. Government Printing Office Washington, DC 20402

(202) 783-3238

FAX (202) 512-2233

8 a.m. to 4:30 p.m., eastern time, M-F

All mail orders should be directed to:

U.S. Government Printing Office

P.O. Box 371954

Pittsburgh, PA 15250-7954

Complimentary subscriptions and single issues are available to certain groups of subscribers, such as public and academic libraries, Federal, State, local and foreign governments, EIA survey respondents, and the media. For further information and for answers to questions on energy statistics, please contact EIA's National Energy Information Center. Address, telephone numbers, and hours are as follows:

National Energy Information Center, EI-231

Energy Information Administration

Forrestal Building, Room 1F-048

Washington, DC 20585

(202) 586-8800

TTY: For people who are deaf or hard

of hearing: (202) 586-1181

9 a.m. to 5 p.m., eastern time, M-F

Released for Printing: July 13, 1995

Printed with soy ink on recycled paper 


\section{DISCLAIMER}

This report was prepared as an account of work sponsored by an agency of the United States Government. Neither the United States Government nor any agency thereof, nor any of their employees, make any warranty, express or implied, or assumes any legal liability or responsibility for the accuracy, completeness, or usefulness of any information, apparatus, product, or process disclosed, or represents that its use would not infringe privately owned rights. Reference herein to any specific commercial product, process, or service by trade name, trademark, manufacturer, or otherwise does not necessarily constitute or imply its endorsement, recommendation, or favoring by the United States Government or any agency thereof. The views and opinions of authors expressed herein do not necessarily state or reflect those of the United States Government or any agency thereof. 


\section{DISCLAIMER}

Portions of this document may be illegible in electronic image products. Images are produced from the best available original document. 
DOE/EIA-0293(95)

Distribution Category UC-950

\title{
Directory of Energy Information Administration Models 1995
}

\author{
July 1995 \\ Energy Information Administration \\ Office of Statistical Standards \\ U.S. Department of Energy \\ Washington, DC 20585
}

This report was prepared by the Energy Information Administration, the independent statistical and analytical agency within the Department of Energy. The information contained herein should not be construed as advocating or reflecting any policy position of the Department of Energy or any other organization. 



\section{Preface}

This directory revises and updates the Directory of Energy Information Administration Models 1994, DOE/EIA-0293(94), Energy Information Administration (EIA), U.S. Department of Energy, July 1994. The Disruption Impact Simulator (DIS) Model in use by EIA has also been included. Model descriptions have been updated according to revised documentation approved during the past year.

This Directory has been published annually. After this issue, it will only be published biennially with the next issue scheduled for mid-1997.

Publication of this directory is supported by Public Law 93-275, Federal Energy Administration Act of 1974, Section 57(B)(1) (as amended by Public Law 94-385), Energy Conservation and Production Act, which states in part,

...that adequate documentation for all statistical and forecast reports prepared...is made available to the public at the time of publication of such reports.

With respect to its modeling efforts, EIA issued the following standards in 1991: Standard 91-01-01, Model Acceptance; Standard 91-01-02, Active Model Inventory Requirements; Standard 91-01-03, Model Documentation; and Standard 91-01-04, Model Archival. In 1992, Standard 92-01-05, Proprietary Models, which describes the necessary actions governing the use of proprietary models (i.e., models available to EIA through license, purchase, or subscription) in EIA reports and modeling systems, was issued.

This directory contains descriptions about each model, including the title, acronym, purpose, followed by more detailed information on characteristics, uses, and requirements. Sources for additional information are identified. Included in this directory are 37 EIA models active as of February 1, 1995. Models that run on personal computers are identified by "PC" as part of the acronym. The models are divided into two groups and listed in alphabetical order within those groups. The first group of models is the National Energy Modeling System (NEMS) models. The second group is all other EIA models that are not part of NEMS.

Appendix A identifies major EIA modeling systems and the models within these systems. Appendix B is a summary of the Annual Energy Outlook Forecasting System. The Annual Energy Outlook 1995 used the NEMS projections and analyses of energy supply, demand, and prices through 2010. 



\section{Contents}

Models of the Energy Information Administration . . . . . . . . . . . . . . . . . . . . . . . 1

Models of the National Energy Modeling System ． . . . . . . . . . . . . . . . . . . . . 1

Coal Market Module (CMM) ．．．．．．． . . . . . . . . . . . . . . . . . . . . . . . . . . . . 1

Commercial Sector Demand Module (CSDM) . . . . . . . . . . . . . . . . . . . . . . . . . . . . . 4

DRI Model of the U.S. Economy (DRI) ． . . . . . . . . . . . . . . . . . . . . . . . . . . . . . . 6

Electricity Market Module (EMM-NEMS) ． . . . . . . . . . . . . . . . . . . . . . . . . . . . . . 7

Industrial Demand Module (IDM) . . . . . . . . . . . . . . . . . . . . . . . . . . . . . . . 11

Integrating Module of the National Energy Modeling System (NEMS) ～. . . . . . . . . . . . . . . . 12

International Energy Module (IEM) . . . . . . . . . . . . . . . . . . . . . . . . . . . . . 14

Macroeconomic Activity Module (MAM) . . . . . . . . . . . . . . . . . . . . . 15

Natural Gas Transmission and Distribution Module (NGTDM) . . . . . . . . . . . . . . . . . 17

Oil and Gas Supply Module (OGSM) ～. . . . . . . . . . . . . . . . . . . . . . . . . . . . . . . . 20

Petroleum Market Module (PMM) . . . . . . . . . . . . . . . . . . . . . . . . . . . . . . . . 22

Renewable Fuels Module (RFM) . . . . . . . . . . . . . . . . . . . . . . . . . . . . . . . . . 24

Residential Sector Demand Module (RSDM) . . . . . . . . . . . . . . . . . . . . . . . . . 29

Transportation Sector Module (TRAN) . . . . . . . . . . . . . . . . . . . . . . . . . 31

"WORLD" Reference Model (WOR) . . . . . . . . . . . . . . . . . . . . . . . . . . . . . . . . . 33

Other EIA Models . . . . . . . . . . . . . . . . . . . . . . . . . . . . . . . . . . . . . . . . . 34

Disruption Impact Simulator Model (DIS) . . . . . . . . . . . . . . . . . . . . . . . . . . 34

Distillate Market Model (DMM) _ . . . . . . . . . . . . . . . . . . . . . . 35

International Nuclear Model - Personal Computer (PCINM) . . . . . . . . . . . . . . . . . . . 36

Levelized Nuclear Fuel Cycle Cost Model (LNFCC-PC) . . . . . . . . . . . . . . . . . . . . 38

Low-Income Household Energy Assistance Program (LIHEAP) . . . . . . . . . . . . . . . . . . . . . 39

Market Penetration Model for Ground Water Heat Pump Systems (MPGWHP-PC) ～. . . . . . . . . . . . 41

Market Penetration Model for Residential Rooftop Photovoltaic Systems (MPRESPV-PC) ～. . . . . . . . . . 42

Market Penetration Model for Active and Passive Solar Technologies (MPSOLAR-PC) . . . . . . . . . . . . 44

Motor Gasoline Market Model (MGMM) ． . . . . . . . . . . . . . . . . . . . . . . . . . . . . . 46

Oil Market Simulation Model (OMS-PC) . . . . . . . . . . . . . . . . . . . . . . . . . . . . 47

Petroleum Financial Analysis System (PETFAS-PC) ． . . . . . . . . . . . . . . . . . . . . . . . 49

Propane Market Model (PPMM) . . . . . . . . . . . . . . . . . . . . . . . . . . . . 50

Refinery Yield Model Spreadsheet System (RYMSS-PC) ～. . . . . . . . . . . . . . . . . 51

Resource Allocation and Mine Costing Model (RAMC) . . . . . . . . . . . . . . . . . . . . . . 54

Revenue Requirements Modeling System (RRMS) . . . . . . . . . . . . . . . . . . . . . . . . 59

Short-Term Coal Analysis System (SCOAL) . . . . . . . . . . . . . . . . . . . . . . . . .61

Short-Term Integrated Forecasting System (STIFS) ． . . . . . . . . . . . . . . . . 63

Short-Term Nuclear Annual Power Production Simulation (SNAPPS) . . . . . . . . . . . . . . . . . . 67

Uranium Market Model (UMM-PC) . . . . . . . . . . . . . . . . . . . . . . . . . 70

Wellhead Gas Productive Capacity Model (GASCAP) ． . . . . . . . . . . . . . . . . . . . . . . 71

World Energy Projection System (WEPS-PC) ． . . . . . . . . . . . . . . . . . . . . . . . . 73

World Integrated Nuclear Evaluation System (WINES-PC) _ . . . . . . . . . . . . . . . . 75

Appendix A - Major Modeling Systems and Contributing Models ～. . . . . . . . . . . . . . . . . . . 81

Appendix B - AEO 95 Forecasting System . . . . . . . . . . . . . . . . . . . . . . 85 


\section{Models of the Energy Information Administration}

\section{Models of the National Energy Modeling System}

\section{Coal Market Module (CMM)}

Description: The Coal Market Module (CMM) represents the mining, transportation, and pricing of coal, subject to the end-use demand for coal differentiated by physical characteristics such as heat, sulfur, and ash content. The CMM also determines U.S. coal exports as part of the worldwide market for coal trade. Coal supply is projected on a cost-minimizing basis constrained by existing contracts. The expansion of existing coal-mining capacity is related to the expected domestic and international demand for coal. Twenty-eight different coal types are modeled, each differentiated with respect to thermal grade, sulfur content and underground or surface mining. The domestic production and distribution of coal is forecast in terms of 16 supply regions and 23 demand regions.

Last Model Update: March 1995.

Part of Another Model? Part of the National Energy Modeling System (NEMS).

Model Interfaces:

- Coal Production Submodule (CPS) interfaces:

- Coal Distribution Submodule, Electricity Market Module, Petroleum Market Module, and Macroeconomic Activity Module.

- Coal Export Submodule (CES) can interface:

- Coal Distribution Submodule

- Coal Distribution Submodule (CDS) interfaces:

- Within the Coal Market Module, the CDS interfaces with the Coal Export Submodule and the Coal Production Submodule.

- Within NEMS, CDS interfaces with the Industrial Demand Module, Residential Demand Module, Commercial Demand Module, Electricity Market Module, and the Macroeconomic Activity Module.
Sponsor:

- Office: Office of Integrated Analysis and Forecasting

- Division: Energy Supply and Conversion Division

- Branch: Coal, Uranium and Renewable Fuels Analysis Branch, EI-822

- Model Contacts and Telephone:

- Coal Production Submodule (CPS)-Mike Mellish $-202-586-2136$

- Coal Export Submodule (CES)-Melinda Hobbs202-586-0012

- Coal Distribution Submodule (CDS)-Richard Newcombe-202-586-2415

Documentation:

- Energy Information Administration, Model Documentation, Coal Market Module of the National Energy Modeling System, DOE/EIA-M060 (Washington, DC, March 1994).

- Energy Information Administration, Model Documentation, Coal Market Module of the National Energy Modeling System, DOE/EIA-M060 (Washington, DC, March 1995).

Archive Media and Installation Manual(s):

- NEMS-94 (Part of the National Energy Modeling System archive package for the Annual Energy Outlook 1994, DOE/EIA-0383(94)).

- NEMS-95 (Part of the National Energy Modeling System archive package for the Annual Energy Outlook 1995, DOE/EIA-0383(95)).

Purpose: The CMM provides annual forecasts of prices, production, and consumption of coal for NEMS.

Energy System Described by Model: U.S. coal production and transportation, and international coal trade. 


\section{Coverage:}

\section{- Geographic:}

- CPS - Supply curves for 16 geographic regions

- CES - 16 export regions (5 of which are U.S.) and 20 import regions ( 4 of which are U.S.)

- CDS - United States, excluding Hawaii, Puerto Rico, and island territories in Caribbean and Pacific

- Time Unit/Frequency: Annual forecasts through 2010

- Product(s):

- CPS - 16 coal types

- CES - Coking, high-sulfur bituminous coal, lowsulfur bituminous coal, and subbituminous coal

- CDS - bituminous, subbituminous and lignite coals in steam and metallurgical coal markets.

- Economic Sector(s):

- CPS - Coal producers and importers

- CES - Coking and thermal

- CDS - Forecasts coal supply to 1 residential/commercial, 3 industrial, 2 domestic metallurgical, 3 export, and 13 electric utility subsectors in 23 domestic demand regions.

Modeling Features: Separate coverage for each of the three CMM submodules is provided below:

\section{Coal Production Submodule:}

- Model Structure: The CPS employs regression models to determine capacity utilization and marginal costs for underground and surface coal mines.

- Modeling Technique: Four steps are involved in the construction of the coal supply curves:

- Project coal production capacity by region, mine type, and coal type

- Estimate relationship between capacity utilization and marginal cost

- Construct generic coal supply curves

- Adjust supply curves for reserve depletion, labor productivity changes, and changes in real labor and fuel costs.
- Special Features: None.

\section{Coal Export Submodule:}

- Model Structure: The CES model satisfies coal import demands at the lowest cost given specified supply and transportation.

- Modeling Technique: The model is a small Linear Program (LP) that satisfies demands at all points at the minimum overall world coal cost plus transportation cost.

- Special Features: The CES is designed for the analysis of legislation concerned with $\mathrm{SO}_{2}$ emissions and the trade nonconventional coals (high-sulfur and subbituminous coal).

\section{Coal Distribution Submodule:}

- Model Structure: The CDS uses 202 coal supply curves representing 28 types of coal produced in 16 supply regions. Coal shipments to consumers are represented by transportation rates specific to NEMS sector and supply/demand region pair, based on historical differences between minemouth and delivered prices for such coal movements. Coal supplies are delivered to up to 22 demand sectors in each of the 23 demand regions. A single model run represents a single year, but up to 26 consecutive years (1990 - 2015) may be run in an iterative fashion. Currently NEMS provides demand input for a 20-year period (1990 - 2010).

- Modeling Technique: The model develops a disaggregated demand list from the NEMS demand models and conversion models for the residential/commercial, industry and electric utility sectors, and from the NEMS Coal Market Module's Coal Export Submodule (q.v.) for export coal demands. This list contains between 600 and 800 demands--referred to as demand jobs--depending on the forecast year and scenario. Least cost coal source/route combinations (minemouth costs plus transportation costs) from each supply region to each demand region for each demand job are identified by a shortest path algorithm. An heuristic equilibrium assignment algorithm is used to shift fractions of demand toward lower costs source/route combinations--called participants. The second algorithm is required because mining costs vary directly as a function of volume mined. The CDS iterates the shortest path algorithm after recosting the participants and repeats the heuristic participation shifting algorithm until convergence criteria for the equality of delivered costs across participants in each demand job are met.

- Special Features: None.

Non-DOE Input Sources: Separate coverage for each of the three CMM submodules is provided below: 
- Coal Production Submodule:

- U.S. Department of Labor, Bureau of Labor Statistics.

- Establishment data: employment, hours, and earnings

- Coal Export Submodule:

- Dr. Guy Doyle, McClosky Coal Information, Ltd. Published trade and business journal articles, including Coal Week International, King's International Coal Trade, Financial Times International Coal Report, World Coal, IEA.

- Coal import demands

- Coal supply curves

- Diversity constraints

- Sulfur emission constraints

- Subbituminous and high-sulfur coal constraints

- Coal Distribution Submodule:

- U.S. Department of Commerce, Bureau of the Census, Monthly Report IM 145: Coal Imports.

- Coal imports by rank, value, tonnage, and port district

- U.S. Department of Commerce, Bureau of the Census, Monthly Report IM 545: Coal Exports.

- Coal exports by rank, value and tonnage from each port district

- Association of American Railroads, AAR Railroad Car Indices (Washington, DC, quarterly).

- $\quad$ Rand McNally and Co., Handy Railroad Atlas of the United States (Chicago, IL, 1988).

- 1986 - 1987 Fieldston Coal Transportation Manual, Ed. John E. Lescourt (Washington, DC, 1986).

\section{DOE Data Input Sources:}

Separate DOE inputs for each of the three CMM submodules is provided below:

\section{- Coal Production Submodule:}

- Energy Information Administration, Form EIA-6, "Coal Distribution Report."
- Coal stocks, delivered prices, and consumption

- Energy Information Administration, Form EIA7A, "Coal Production Report."

- Production, minemouth prices, coal seams mined, labor productivity, employment, stocks, and recoverable reserves at mines. A supplement in 1983 covered prices, Btu, ash, and sulfur content as sold to individual economic sectors; these data were collected on a "Dry" basis.

- Energy Information Administration, Petroleum Marketing Annual 1990, DOE/EIA-0487(90) (Washington, DC, 1990).

- Energy Information Administration, Resource Allocation and Mine Costing Model and data library.

- Federal Energy Regulatory Commission, FERC Form 423, "Monthly Report of Cost and Quality of Fuels for Electric Plants."

- Delivered cost, receipts, ash, Btu, sulfur ("as received" basis), and sources

- Coal Export Submodule: None.

- Coal Distribution Submodule:

- Energy Information Administration, Form EIA-3, "Quarterly Coal Consumption Report, Manufacturing Plants."

- Coal stocks, delivered prices, and consumption

- Energy Information Administration, Form EIA-5, "Coke Plant Report - Quarterly."

- Consumption, delivered prices, and stocks

- Energy Information Administration, Form EIA-6, "Coal Distribution Report."

Distribution from mine to consumer by economic sector, transport mode, and tonnage

- Energy Information Administration, Form EIA7A, "Coal Production Report."

- Production, minemouth prices, coal seams mined, labor productivity, employment, stocks, and recoverable at reserves mines 
- Federal Energy Regulatory Commission, FERC Form 423, "Monthly Report of Cost and Quality of Fuels at Electric Plants."

- Delivered cost, receipts, ash, Btu, sulfur ("as received" basis), and sources

- Federal Energy Regulatory Commission, FERC Form-580, "Interrogatory on Fuel and Energy Purchase Practices."

- Coverage of contractual base tonnage, tonnage shipped, ash, Btu, sulfur and moisture ("as received" basis), minemouth price, freight charges, coal source and destination, shipping modes, transshipments (if any), and distances.

\section{General Output Descriptions:}

\section{- CPS}

- Annual coal supply curves (price/production schedules) are provided for each supply region, mining method, and coal type.

- CES

- World coal trade flows by coal export region/coal import region/coal type/coal demand sector (specified in units of million metric tons of coal equivalent).

\section{- CDS}

- Physical: Forecasts of annual coal supply tonnages (and trillion Btu) by economic sector and subsector, coal supply region, coal Btu and sulfur content, and demand region.

- Economic: Forecasts of annual minemouth, transportation and delivered coal prices by coal type, economic sector, coal demand and supply regions.

Computing Environment:

- Hardware Used: IBM 3090

- Operating System: MVS

- Language/Software Used: OML/FORTRAN 77

- Memory Requirement: $4,000 \mathrm{Mb}$

- Storage Requirement: 859 tracks

- Estimated Run Time: $10 \mathrm{CPU}$ seconds for a single

- Special Features: None.
Independent Reviews Conducted:

- Independent Expert Review conducted by Charles D. Kolstad, Review of Volume I of the Documentation of the Coal Market Module of NEMS, Memorandum to William Weinig, Office of Statistical Standards, EIA, January 20, 1994.

- Independent Expert Review conducted by Stanley C. Suboleski, Review of NEMS Model Documentation, Volume I, Memorandum to William Weinig, Office of Statistical Standards, EIA, January 10, 1994.

- Independent Expert Review conducted by Charles D. Kolstad, Report of Findings and Recommendations on EIA's Component Design Report Coal Export Submodule, prepared for the Energy Information Administration (Washington, DC, April 9, 1993).

- Independent Expert Review conducted by Charles D. Kolstad, Report of Findings and Recommendations on EIA's Component Design Report Coal Distribution Submodule, prepared for the Energy Information Administration (Washington, DC, August 31, 1992).

- Independent Expert Review conducted by Stanley C. Suboleski, Report Findings and Recommendations, Coal Production Submodule Review of Component Design Report, prepared for the Energy Information Administration (Washington, DC, August 27, 1992).

- Independent Expert Review conducted by Charles D. Kolstad, Report of Findings and Recommendations on EIA's Component Design Report Coal Production Submodule, prepared for the Energy Information Administration (Washington, DC, July 23, 1992).

Status of Evaluation Efforts by Sponsor: None.

\section{Commercial Sector Demand Module (CSDM)}

Description: The NEMS Commercial Sector Demand Module is a simulation tool based upon economic and engineering relationships that models commercial sector energy demands at the 9 Census Division level of detail for 11 distinct categories of commercial buildings. Commercial equipment selections are performed for the major fuels of electricity, natural gas, and distillate fuel, for the major services of space heating, space cooling, water heating, ventilation, cooking, lighting and refrigeration. The market segment level of detail is modeled using a constrained life-cycle cost minimization algorithm that considers commercial sector consumer behavior and time preference premiums. The algorithm also models the minor fuels of residual oil, liquefied petroleum gas, steam coal, motor gasoline, and kerosene; the renewable fuel sources of wood and municipal solid waste; and the minor 
services of office equipment, refrigeration, and other in less detail than the major fuels and services.

Last Model Update: November 1994.

Part of Another Model? National Energy Modeling System (NEMS)

Model Interfaces: Receives inputs from the Electricity Market Module, Oil and Gas Market Module, Renewable Fuels Module, and Macroeconomic Activity Module within NEMS. Outputs are provided to the Electricity Market Module, Oil and Gas Market Module, and Integrating Module.

\section{Sponsor:}

- Office: Office of Integrated Analysis and Forecasting

- Division: Energy Demand and Integration Division

- Branch: Energy Demand Analysis Branch, EI-813

- Model Contact: Erin Boedecker

- Telephone: $202-586-4791$.

Documentation: Energy Information Administration, Model Documentation Report: Commercial Sector Demand Module of the National Energy Modeling System, DOE/EIA-M066(95) (Washington, DC, February 1995).

Archive Media and Installation Manual(s):

- NEMS-94 (Part of the National Energy Modeling System archive package for the Annual Energy Outlook 1994, DOE/EIA-0383(94)).

- NEMS-95 (Part of the National Energy Modeling System archive package for the Annual Energy Outlook 1995, DOE/EIA-0383(95)).

Purpose: The CSDM generates mid-term forecasts of commercial sector energy demand. The model facilitates policy analysis of energy markets, technological development, environmental issues, and regulatory development as they impact commercial sector energy demand.

Energy System Described by Model: Domestic commercial sector energy consumption.

\section{Coverage:}

- Geographic: Nine Census Divisions: New England, Mid-Atlantic, East North Central, West North Central, South Atlantic, East South Central, West South Central, Mountain, Pacific

- Time Unit/Frequency: Annual, 1990 through 2010
- Product(s): Electricity, natural gas, distillate, residual oil, liquefied petroleum gas, coal, motor gasoline, kerosene, wood, municipal solid waste

- Economic Sector(s): Eleven building categories: assembly, education, food sales, food services, health care, lodging, large office, small office, mercantile \& service, warehouse, other. Nine services: space heating, space cooling, water heating, ventilation, cooking, lighting, office equipment, refrigeration, other.

\section{Modeling Features:}

- Model Structure: Sequential calculation of forecasted commercial floorspace, service demand, technology choice, and end-use consumption.

- Modeling Technique: Simulation of technology choice by decision type, within a service, within a building and Census Division, for the current year of the forecast. Commercial Buildings Energy Consumption Survey 1989 data are used for initial floorspace, market shares, fuel shares, district service shares. Engineering analyses used for initial efficiency estimates.

- Special Features: Technology choice data base and simulation technique is capable of accommodating an extensive range of policy analyses, including but not limited to demand-side management capital incentives, tax credits, and equipment efficiency standards.

\section{Non-DOE Input Sources:}

- Data Resources Inc. (DRI), F.W. Dodge.

- Historical commercial sector floorspace by Census Division and building type, for the years 19701990

- Historical floorspace retirement proportion by Census region for the year 1990

- Description of floorspace categorization to enable mapping to DOE sources

- Arthur D. Little Technical Reports, EPRI Technical Assessment Guide, GRI Baseline Data Book.

- Commercial sector existing equipment characteristics, including typical equipment capacity, installed capital cost, operating and maintenance (O\&M) cost, expected physical lifetime, based on data from the years 1986-1993

- Equipment research and development (R\&D) advances and projected dates of model introduction, projections for technology availability encompassing the years 1995-2010. 
DOE Data Input Sources:

Forms and Publications:

- Energy Information Administration, Form EIA-867, "Annual Nonutility Power Producer Report" for years 1989-1991.

- Historical commercial sector quantities of cogenerated electricity by Census Division, generating fuel, and building type

- Annual consumption of fuels for cogeneration by Census Division and building type

- Current status of commercial sector generating facilities

- Current outlook for commercial sector generating capacity, to determine planned and unplanned additions to capacity

- Energy Information Administration, Form EIA871A/F, "Commercial Building Energy Consumption Survey 1989" (CBECS 1989).

- Base-year floorspace by Census Division, building type, building age cohort, energy-consuming characteristics

- Base-year district service consumption totals and relative shares

- Base-year Energy Use Intensity (EUI) by Census Division, building type, and energy service

- Base-year equipment stock characteristics by Census Division and energy service

- Base-year energy consumption for calculation of nonbuilding consumption to benchmark

Models and Other:

- National Renewable Energy Laboratory (NREL) Interlaboratory Documentation, 1990.

- Forecasted commercial sector renewable energy demand, by renewable source and energy service.

General Output Descriptions: The Commercial Model provides sectoral fuel consumption forecasts to be used by other NEMS modules.

Computing Environment:

- Hardware Used: IBM 3090

- Operating System: MVS
- Language/Software Used: VS FORTRAN, Ver. 2.05

- Memory Requirement: 3,000Mb

- Storage Requirement: 188 tracks

- Estimated Run Time: 3.5 minutes for a 1990-2015 run in noniterating NEMS mode on an IBM 3090

- Special Features: None.

Independent Reviews Conducted: Independent Expert Reviews of Commercial Sector Component Design Report, July 31, 1992, conducted by David Belzer, Pacific Northwest Laboratory; Richard E. Jones, Office of Building Technologies, Conservation and Renewable Energy: James E. McMahon, Ph.D., Lawrence Berkeley Laboratory; Robert P. Trost, Ph.D., and Inderjit Kundra, Office of Statistical Standards.

Status of Evaluation Efforts by Sponsor: None.

\section{DRI Model of the U.S. Economy (DRI)}

Description: The DRI Model represents national economic production and income corresponding to the National Income and Product Accounts published by the Department of Commerce. These forecasts of national activity extend 25 years and serve as the basis for EIA macroeconomic forecasts. EIA alters the DRI forecasts so that the energy variables included in the macroeconomic model correspond to EIA energy price forecasts.

Last Model Update: December 1993.

Part of Another Model? No.

Model Interfaces: None.

Sponsor:

- Office: Office of Integrated Analysis and Forecasting

- Division: Energy Demand and Integration Division

- Branch: International Economic and Integrated Forecasting Branch, EI-812

- Model Contact: Kay Smith

- Telephone: 202-586-1455

Documentation: Energy Information Administration, Documentation of the DRI Model of the U.S. Economy, DOE/EIA-M061 (Washington, DC, December 1993). 
Archive Media and Installation Manual(s): This is a proprietary model and is not archived.

Purpose: EIA uses the DRI Model of the U.S. Economy to generate macroeconomic growth cases. These growth cases are then used by the Macroeconomic Module (MAM) of NEMS to calculate macroeconomic feedback of changing energy prices.

\section{Energy System Described by Model: None.}

\section{Coverage:}

- Geographic: Quarterly forecasts for 25 years at a national level.

\section{- Time Unit/Frequency: Quarterly}

- Product(s): Personal consumption expenditures, producers durable equipment investment, nonresidential construction, residential construction and nondefense Government expenditures, Federal defense expenditures, exports, imports, inventory change in final goods, and inventory change in materials and work-in-process.

- Economic Sector(s): Domestic spending, domestic income, tax policy, international, financial, inflation, simulated supply potential, expectations.

Modeling Features:

- Model Structure: The DRI Model forecasts roughly 1,200 concepts encompassing final demands, aggregate supply, prices, incomes, interest rates, industrial detail, and international trade. There are eight blocks to the model: Domestic spending, domestic income, tax sector, prices, financial, international trade, expectations, and aggregate supply. The domestic spending, income and tax blocks correspond to the National Income and Product Accounts. The rest of the blocks interact with the blocks describing domestic activity.

- Modeling Technique: Econometric simulation modeling techniques.

- Special Features: None.

\section{Non-DOE Input Sources:}

- U.S. Department of Commerce (Washington, DC)

- Consumption

- Investment

- Residential construction

- Exports
- Imports

- Inventory change

- Defense spending.

DOE Data Input Sources: None.

General Output Descriptions: The variables needed by MAM for the macroeconomic growth cases.

Computing Environment:

- Hardware Used: IBM-compatible personal computer (PC) with math coprocessor

- Operating System: DOS Ver. 5.0

- Language/Software Used: Proprietary DRI model software

- Memory Requirement: $640 \mathrm{~Kb}$

- Storage Requirement: $5 \mathrm{Mb}$

- Estimated Run Time: 20 minutes on 486 chip for 25-year simulation

- Special Features: None.

Independent Reviews Conducted: None.

Status of Evaluation Efforts by Sponsor: None.

\section{Electricity Market Module (EMM- NEMS)}

Description: EMM-NEMS is used by the Energy Information Administration as an analytical system for projecting the future state of the electricity market. This model is a major component of the National Energy Modeling System (NEMS). This representation of the electricity market accounts for the economic factors of supply and demand, the economic competition of fuels, and Government policies and regulations that deviate from purely economic behavior.

The EMM-NEMS consists of four submodules: Electricity Capacity Planning (ECP), Electricity Fuel Dispatch (EFD), Electricity Finance and Pricing (EFP) and Load and Demand-Side Management (LDSM).

Last Model Update: December 1994.

Part of Another Model? Part of the National Energy Modeling System (NEMS). 
Model Interfaces: The EMM-NEMS is one of the primary components of NEMS from which it derives estimates of projected fuel prices, cost and performance characteristics for renewable technologies, electricity demand by sector, inflation and interest rates. In addition, cost and performance characteristics for new units are provided by the Argonne National Laboratories via an input database.

\section{Sponsor:}

- Office: Office of Integrated Analysis and Forecasting

- Division: Energy Supply and Conversion Division

- Branch: Nuclear and Electricity Analysis Branch, EI821

- Model Contacts: Jeffrey Jones

- Telephone: 202-586-2038.

Documentation:

- Energy Information Administration, Model Documentation: Electricity Market Module, Load and DemandSide Management Submodule, Volume $1 \mathrm{Model}$ Description, DOE/EIA-M068-A/1 (Washington, DC, March 1994).

- Energy Information Administration, Model Documentation: Electricity Market Module, Load and DemandSide Management Submodule, Volume 2 Model Code Listing DOE/EIA-M068-A/2 (Washington, DC, March 1994).

- Energy Information Administration, Model Documentation: Electricity Market Module, Electricity Capacity Planning Submodule, DOE/EIA-M068-B (Washington, DC, March 1994).

- Energy Information Administration, Model Documentation: Electricity Market Module, Electricity Finance and Pricing Submodule, DOE/EIA-M068-C (Washington, DC, March 1994).

- Energy Information Administration, Model Documentation: Electricity Market Module, Electricity Fuel Dispatch Submodule, DOE/EIA-M068-D (Washington, DC, March 1994).

- Energy Information Administration, Documentation of the Electricity Market Module (EMM) Appendix: Model Developers Report, DOE/EIA-M068(95) Appx (Washington, DC, February 1995).

- Energy Information Administration, Model Documentation: Electricity Market Module, Modifications to the Electricity Capacity Planning Submodule, DOE/EIAM068-B/1 (Washington, DC, April 1995).
Archive Media and Installation Manual(s):

- NEMS-94 (Part of the National Energy Modeling System archive package for the Annual Energy Outlook 1994, DOE/EIA-0383(94)).

- NEMS-95 (Part of the National Energy Modeling System archive package for the Annual Energy Outlook 1995, DOE/EIA-0383(95)).

Purpose: EMM-NEMS' objective is to simulate electric utility behavior in order to produce a forecast of electricity prices, fuel consumption patterns and expansion plans consistent with electricity demand forecasts.

Energy System Described by Model: EMM-NEMS is a process model representing the domestic electricity market. EMM-NEMS represents the conversion of fossil fuels, nuclear power, hydropower and other renewable energy sources into electricity. EMM-NEMS translates the fixed and variable costs of production into electricity prices by simulating electric utility regulatory practices for both privately and publicly owned utilities. In addition, EMM-NEMS formulates capacity plans to provide adequate capacity throughout the forecast horizon.

\section{Coverage:}

- Geographic: 13 Electricity Supply Regions (the 9 North American Reliability Regions and 4 selected subregions to isolate key States or areas)

- Time Unit/Frequency: Annually through 2010

- Product(s): Electricity prices, emissions from electric utilities and nonutilities (excluding cogenerators) of nitrogen oxides $\left(\mathrm{NO}_{2}\right)$, sulfur dioxide $\left(\mathrm{SO}_{2}\right)$, and Carbon compounds $\left(\mathrm{C}, \mathrm{CO}_{1}, \mathrm{CO}_{2}\right)$; consumption of natural gas, oil, nuclear power fossil fuel equivalent, and hydropower/other fossil fuel equivalent.

- Economic Sector(s): Electric utilities and nonutilities.

Modeling Features:

- Model Structure: The EMM-NEMS simulates the decision-making behavior of electric utilities and nonutilities (excluding cogenerators) in choosing the appropriate mix of capacity to construct for future years (ECP, in allocating current plants to satisfy generation requirements (EPD), and in determining electricity prices (EEF) consistent with demand estimates. (The LDSM develops system load shapes for the 13 EMMNEMS regions using demand provided by the Demand Modules). The ECP relies on the Optimization and Modeling (OML) software, a proprietary mathematical programming package, to create and store coefficients in a database, solve the problem, and retrieve the solution. The EFD uses a heuristic approach to 
provide a least-cost solution to allocating capacity to meet demand. The EFP and the LDSM are completely deterministic.

- Modeling Technique: EMM-NEMS is modular in its relation to NEMS and in the relationship among the components which define the model. In addition, the EMM-NEMS is largely data-driven in that the core software (those routines which implement the methodology) is blind to both region and forecast year.

- Special Features: The primary design feature of the EMM-NEMS is its modularity. The model is composed of four loosely linked components: planning (ECP), dispatching (EFD), pricing (EFP) and demand (LDSM). Any of these components may be replaced by a new representation with only minimal direct interface required. Also, the solution for the ECP is written out to a database, which can be used as an input file in order to execute the rest of the EMMNEMS without the ECP.

\section{Non-DOE Input Sources:}

- North American Electric Reliability Council

- Hourly load data

- Oak Ridge National Laboratory, CONCEPT-5 Model

- Construction profiles for new fossil fuel plants

- Environmental Protection Agency

- Emissions allowances for sulfur dioxide

\section{DOE Data Input Sources:}

- FERC Form-1, "Annual Report of Major Electric Utilities, Licensees, and Others," and Form EIA-412, "Annual Report of Publicly Owned Electric Utilities"

- Utility plant in service, aggregated by type

- Construction work in progress

- Accumulated provisions for depreciation, amortization and depletion

- Capital structure

- Federal income taxes and other revenue taxes

- Embedded cost of capital (debt and preferred)

- Electric revenues

- Deferred taxed income and investment tax credits
- Transmission and distribution operations and maintenance data. Note: If financial data from the FERC Form 1 are not used, the "Annual Report to Stockholders, Securities and Exchange Commission," Form 10K, or the utility COMPUSTAT data base can be used.

- Office of Fossil Energy, Form FE-781R, "Annual Report of Electric Power Annual Electrical Export/Import Data."

- Historical international electricity trade

- Energy Information Administration. Electrical Power Annual 1992 (DOE/EIA-0349(92) (Washington, DC, January 1994)

- Historical (1990, 1991, and 1992) utility and nonutility generation and fuel consumption by fuel

- Historic Emissions

- Department of Energy, Northern Lights: The Economic and Practical Potential of Imported Power from Canada (DOE/PE-0079) (Washington, DC).

- Cost and performance of Canadian potential hydroelectric supply.

- International Affairs and Energy Emergencies, Form IE-411, "Coordinated Regional Bulk Power Supply Program Report."

- Existing and planned interregional and international transfers

- Fuel cost adjustment for purchased power

- Adjustments to revenues for bulk power sales

- Energy Information Administration, Form EIA-759, "Monthly Power Plant Report."

- Maximum fuel shares for existing capacity

- Capacity factors for hydroelectric plants

- Energy Information Administration, Form EIA-860, "Annual Electric Generator Report."

- Existing utility capacity

- Heat rates for existing capacity

- Planned utility capacity additions

- Planned utility capacity retirements 
- Energy Information Administration, Form EIA-867, "Annual Nonutility Power Producer Reports."

- Emission rates for existing generating units

- Pollution control equipment installed at existing generating units.

\section{Models and Other:}

- Argonne National Laboratories under contract to Energy Information Administration, Cost and Performance Database.

- Fixed operations and maintenance costs for new fossil fuel and nuclear plants

- Variable operations and maintenance costs for new fossil fuel and nuclear plants

- Planned outages for new fossil fuel and nuclear plants

- Forced outages for new fossil fuel and nuclear plants

- Heat rates for new fossil fuel and nuclear plants

- Operating profile (percent of available hours at indicated load levels) for new fossil fuel and nuclear plants

- Maximum capacity factor for new fossil fuel and nuclear plants

- Maximum availability hours for new fossil fuel and nuclear plants

- Duty cycle for new fossil fuel and nuclear plants

- Scrubber $\mathrm{SO}_{2}$ removal efficiency for new fossil fuel and nuclear plants

- Retrofit factor for new fossil fuel and nuclear plants

- Particulate removal efficiency for new fossil fuel and nuclear plants

- Sludge disposal costs for new fossil fuel and nuclear plants

- Fly and bottom ash disposal costs for new fossil fuel and nuclear plants

- Energy Information Administration, Decision Analysis Corporation of Virginia and ICF Resources Incorporated under Contract Number DE-AC0192E121946, to the U.S. Department of Energy, the DSM options database:
- DSM options in the residential and commercial sectors. Note: This data base is based on a survey of existing utility practices. The sources surveyed include data from the Bonneville Power Administration, Lawrence Berkeley Laboratories, ICF Analysis for the Environmental Protection Agency, Electric Generation Expansion Analysis System (EGEAS) model documentation (Electric Power Research Institute and Stone and Webster Management Consultants, Inc.) and Integrated Resource Planning Reports from State Commissions.

- On Location, Inc., Deliverable 6, "Draft Data Inputs for Implementation of ETT," Task 92086, Contract DE-AC01-88E121033, Memorandum from Less Goudarzi/Joanne Shore to Pat Toner, Energy Information Administration. (March 5, 1993).

- Transmission flow constraints

- Transmission capacity expenditure coefficients

- Transmission losses

- Energy Information Administration, Office of Integrated Analysis and Forecasting

- Nuclear maximum capacity factors

- Annual nuclear fuel costs

- International economy transactions.

General Output Descriptions: EMM-NEMS provides information on electricity demand, supply, and financial information for 13 electricity supply regions (NERC regions and select subregions) as well as for the entire United States. The data are used for analysis by the Department of Energy and other analysts and are published in the Annual Energy Outlook 1995 (national forecast) and the Supplement to the Annual Energy Outlook 1995 (regional forecast).

Computing Environment:

- Hardware Used: IBM 3090QX

- Operating System: MVS

- Language/Software Used: FORTRAN 77

- Memory Requirement: $16,000 \mathrm{~Kb}$

- Storage Requirement: $6,075 \mathrm{~Kb}$

- Estimated Run Time: 1 CPU minute per iteration

- Special Features: None. 
Independent Reviews Conducted:

- Roger Naill, AES, National Energy Modeling System Conference, February 1 and 2, 1993.

- Vance Mullis, Southern Company Services, National Energy Modeling System Conference, February 1 and 2, 1993.

- Larry Makovich, DRI, McGraw-Hill, Inc., National Energy Modeling System Conference, February 1 and 2, 1993.

- Howard E. Thompson, Ph.D., Professor, University of Wisconsin, Madison, Wisconsin, reviewed the Component Design Report for the ECP, October 1992.

- Douglas R. Bohi, Ph.D., Energy and Natural Resources Division, Resources for the Future, Washington, DC, reviewed the Component Design Report for the ECP, October 1992.

- Dallas Burtraw, Ph.D., Fellow, Quality of the Environment Division, Resources for the Future, Washington, DC, reviewed the Component Design Report for the ECP, October 1992.

- Steven R. Elliott, Ph.D., Energy Division, Oak Ridge National Laboratory, Oak Ridge, TN, reviewed the Component Design Report for the ECP, October 1992.

Status of Evaluation Efforts by Sponsor: The model documentation, Volume I, has been reviewed by EIA's Office of Statistical Standards and independent expert reviewers. The office has completed Volume II of the documentation, the Model Developer's Report, which provides sensitivity analysis and scenario output in support of the documentation of model performance.

\section{Industrial Demand Module (IDM)}

Description: The Industrial Demand Module is based upon economic and engineering relationships that model industrial sector energy consumption at the 9 Census Division level of detail. The seven most energy-intensive industries are modeled at the detailed process step level and 25.other industries are modeled at a less detailed level. The IDM incorporates three components: buildings; process and assembly; and boiler, steam, and cogeneration. The model estimates consumption of 22 main fuels, 6 intermediate fuels, and 8 renewable fuels.

Last Model Update: November 1993.

Part of Another Model? Part of the National Energy Modeling System (NEMS)
Model Interfaces: Receives inputs from the Electricity Market Module, Oil and Gas Market Module, Renewable Fuels Module, Macroeconomic Activity Module, and Petroleum Market Module.

Sponsor:

- Office: Office of Integrated Analysis and Forecasting

- Division: Energy Demand and Integration Division

- Branch: Energy Demand Analysis Branch, EI-813

- Model Contact: T. Crawford Honeycutt

- Telephone: $202-586-1420$

Documentation: Energy Information Administration, NEMS Industrial Module Documentation Report, DOE/EIA-M064 (Washington, DC, January 1994).

Archive Media and Installation Manual(s):

- NEMS-94 (Part of the National Energy Modeling System archive package for the Annual Energy Outlook 1994, DOE/EIA-0383(94)).

- NEMS-95 (Part of the National Energy Modeling System archive package for the Annual Energy Outlook 1995, DOE/EIA-0383(95)).

Purpose: IDM generates mid-term forecasts of industrial sector energy consumption. The industrial model facilitates policy analysis of energy markets, technological development, environmental issues, and regulatory developments as they impact industrial sector energy consumption.

Energy System Described by Model: Domestic industrial sector energy consumption.

\section{Coverage:}

- Geographic: Nine Census Divisions: New England, Mid Atlantic, East North Central, West North Central, South Atlantic, East South Central, West South Central, Mountain, and Pacific

- Time Unit/Frequency: Annual, 1990 through 2010

- Product(s): 22 main fuels, 6 intermediate fuels, and 8 renewable fuels

- Economic Sector(s): Industrial sector.

Modeling Features:

- Model Structure: 26 manufacturing and 6 nonmanufacturing industries. The manufacturing 
industries are further subdivided into the energy intensive and non-energy-intensive industries. Each industry is modeled as three separate but interrelated components consisting of the process/assembly component (PA), the buildings component (BLD), and the boiler/steam/cogeneration component (BSC).

- Modeling Technique: Ordinary least-squares with log transformations is used for the nonmanufacturing and non-energy-intensive manufacturing industries. The energy-intensive industries are modeled through the use of a detailed process flow accounting procedure.

- Special Features: None.

Non-DOE Input Sources:

- National Energy Accounts

- Major industrial power plant database

- Historical dollar value of output in the industrial sector

DOE Data Input Sources:

Forms and Publications:

- Energy Information Administration, Form EI-867, "Annual Nonutility Power Producer Report"

- Electricity generation, total and by prime mover

- Electricity generation for own use and sales

- Capacity utilization

- Energy Information Administration, Form EIA, 846, "Manufacturing Energy Consumption Survey 1988," May 1991

Models and Other:

- None.

General Output Descriptions: The Industrial Demand Model develops forecasts of industrial sector energy consumption.

Computing Environment:

- Hardware Used: IBM 3090QX

- Operating System: MVS

- Language/Software Used: VS FORTRAN, Ver 2.05

- Memory Requirement: $437 \mathrm{~Kb}$

- Storage Requirement: 1,397 tracks
- Estimated Run Time: 1.1 minutes for a 1990 - 2010 in noniterating NEMS mode on an IBM 3090

- Special Features: None.

Independent Reviews Conducted: None.

Status of Evaluation Efforts by Sponsor: The Model Developer's Report was completed in June 1994.

\section{Integrating Module of the National Energy Modeling System (NEMS)}

Description: NEMS represents a general equilibrium solution of the interactions between the U.S. energy markets and the economy. The model achieves a supply-anddemand balance in the end-use demand regions, defined as the nine Census divisions, by solving for the prices of each energy type such that the quantities producers are willing to supply equal the quantities consumers wish to consume. The system reflects market economics, industry structure, and energy policies and regulations that influence market behavior.

Last Model Update: December 1994.

Part of Another Model? Yes. Part of the National Energy Modeling System (NEMS).

Model Interfaces:

- The NEMS Integrating Module integrates the efforts of the following submodels:

- Oil and Gas Supply Module

- Natural Gas Transmission and Distribution Module

- Coal Market Module

- Renewable Fuels Module

- Electricity Market Module

- Petroleum Market Module

- Residential Sector Demand Module

- Commercial Sector Demand Module

- Transportation Sector Demand Module

- Industrial Sector Demand Module

- Macroeconomic Activity Module

- International Energy Activity Module. 
Sponsor:

- Office: Office of Integrated Analysis and Forecasting

- Division: Energy Demand and Integration Division

- Branch: National Energy Modeling System Branch, EI-811

- Model Contact: Daniel H. Skelly

- Telephone: 202-586-1722.

\section{Documentation:}

- Energy Information Administration, NEMS Integrating Module Documentation Report, DOE/EIA-M057 (Washington, DC, December 1993).

- Energy Information Administration, NEMS-An Overview, DOE/EIA-0581, (Washington, DC, May 1994).

Archive Media and Installation Manual(s):

- NEMS-94 (Part of the National Energy Modeling System archive package for the Annual Energy Outlook 1994, DOE/EIA-0383 (94)).

- NEMS-95 (Part of the National Energy Modeling System archive package for the Annual Energy Outlook 1995, DOE/EIA-0383 (95)).

Purpose: NEMS accounts for the many interactions of the different segments of the energy industries and to provide an internally consistent forecast of prices and quantities for which supply equals demand. This equilibrium solution accounts for the main economic factors that affect supply and demand, allows price competition of fuels, and accounts for policies and regulations that cause deviations from purely economic behavior.

Energy System Described by Model: NEMS is a general equilibrium model of domestic energy supply and demand. It represents the domestic production of oil, natural gas, refined petroleum products, coal and electricity. It also represents the two major energy conversion activities--the refining of crude oil into petroleum products and the conversion of fossil fuels, nuclear power, hydropower, and other renewable sources into electricity. Consumption of energy is represented by four end-use sectors: residential, commercial, industrial, and transportation.

\section{Coverage:}

- Geographic: Nine Bureau of Census Divisions. Some component analytical modules represent energy production or conversion at different levels of regional detail. All equilibration takes place at the Census division level.
- Time Unit/Frequency: Annual through 2010

- Product(s): Natural gas, electricity, coal, steam coal, metallurgical coal, distillate fuel oil, residual fuel oil, motor gasoline, jet fuel, liquefied petroleum gases, petrochemical feedstocks, kerosene, other petroleum products, hydropower, and other renewable sources.

- Economic Sector(s): Residential, commercial, industrial, and transportation end-use consumption; coal supply; oil and gas production and natural gas markets; utility and nonutility capacity, generation of electricity; and oil product pricing.

\section{Modeling Features:}

- Model Structure: NEMS provides an equilibrium framework in which the economic forces of supply and demand can be simulated. Its modular structure allows each individual module to be represented in a different fashion if desired.

- Modeling Technique: NEMS is a simulation of the impacts of present and planned energy market conditions upon the supplies of and demands for energy products. Different techniques are applied in different sectors, as appropriate.

- Special Features: The primary design feature of NEMS is its modularity. That is, the model is organized by fuel production--oil, natural gas, coal, and electricity-and by end-use consumption sector. Any of these modules can be replaced by a simple representation when detailed results are not required. The modularity also allows any single module or group of modules to be run independently as a debugging aid or for stand-alone analysis. Furthermore, modularity also allows the flexibility for each sector to be represented in the most appropriate way, highlighting the particular issues important for the sector, including the most appropriate regional structure.

Non-DOE Input Sources: All data sources are listed under the appropriate modules of NEMS, which are listed in the Model Interfaces section.

\section{DOE Data Input Sources:}

All data sources are listed under the appropriate modules of NEMS, which are listed in the Model Interfaces section.

General Output Descriptions: The following are generally used in published reports:

- Total energy supply and disposition

- Domestic production by fuel type

- Imports and exports by fuel type 
- Electric utility and nonutility fuel consumption, generation and capacity

- Electricity trade, sales, and end-use sectoral and regional prices

- Petroleum supply, disposition, and end-use sectoral and regional prices

- Natural gas supply, disposition, and end-use sectoral and regional prices

- Crude oil and natural gas production by category, reserves, and well completions

- Coal supply, disposition, and end-use sectoral and regional prices

- Renewable energy capability, generation, and consumption

- Consumption of energy by fuel, sector, and region.

Computing Environment:

- Hardware Used: IBM 3090QX

- Operating System: MVS

- Language/Software Used: FORTRAN 77

- Memory Requirement: Over $60 \mathrm{Mb}$ when all modules are being executed.

- Storage Requirement:

- Estimated Run Time: 24 hours when all modules are being executed

- Special Features: NEMS is designed to operate in a mainframe computing environment that allows in excess of 16 megabytes of main memory.

Independent Reviews Conducted: None.

Status of Evaluation Efforts by Sponsor: Currently undergoing evaluation.

\section{International Energy Module (IEM)}

Description: IEM is a recursive model of world petroleum supply and demand by region derived from EIA's Oil Market Simulation Model (OMS-PS) with enhanced detail on U.S. market conditions from the NEMS Petroleum Market Module (PMM). Determines PAD district-level import supply schedules by refined product type and crude oil grade consistent with estimated world oil price. IEM outputs include forecasted world oil price, non-OPEC oil production and oil consumption by region, and OPEC oil production and capacity utilization.

Last Model Update: April 1994.

Part of Another Model? National Energy Modeling System (NEMS).

Model Interfaces: Inputs: NEMS Petroleum Market Module (PMM), Short-Term Integrated Forecasting System (STIFS), World Energy Projections System (WEPS), WEFA International Macro Model. Outputs: NEMS System Module and PMM.

Sponsor:

- Office: Office of Integrated Analysis and Forecasting

- Division: Energy Demand and Integration Division

- Branch: International, Economic and Integrated Forecasting Branch, EI-812

- Model Contact: Dan Butler

- Telephone: 202-586-9503

Documentation:

- Energy Information Administration, NEMS International Energy Module Model Documentation Report, DOE/EIA-M071 (Washington, DC, April 1994).

Archive Media and Installation Manual(s):

- NEMS-94 (Part of the National Energy Modeling System archive package for the Annual Energy Outlook 1994, DOE/EIA-0383 (94)).

- NEMS-95 (Part of the National Energy Modeling System archive package for the Annual Energy Outlook 1995, DOE/EIA-0383 (95)).

Purpose: IEM forecasts world oil price based on either an exogenously specified OPEC output path or OPEC pricing behavior and estimates U.S. import supplies of crude oil, refined petroleum products, and oxygenated gasoline blending components to allow estimation of U.S. oil supply and demand balances.

Energy System Described by Model: The model describes world oil supply and demand on a regional basis annually from present time through 2010. 


\section{Coverage:}

- Geographic:

- Demand Regions: (50 States and territories), Canada, Japan, Australia and New Zealand, OECD Europe, rest of world (excluding Eurasia)

- Supply Regions: United States, Canada, Japan, OECD Europe, OPEC, rest of world (excluding Eurasia)

- U.S.Detail: PAD district-level import supply curves

- Time Unit/Frequency: Annually from 1990 to 2010

- Product(s): 5 grades of crude oil, 10 refined products, and 2 oxygenates (methanol and methyl tertiary butyl ether (MTBE))

- Economic Sector(s): Major oil-consuming countries, regionalized above.

\section{Modeling Features:}

- Model Structure: The model includes three subcomponents: The World Oil Market (WOM); Petroleum Product Supply (PPS); and Oxygenates Supply (OS). The structure of the WOM component is based on the OMS model, with greater U.S. detail from NEMS PMM.

- Modeling Technique: Recursive simulation (search for equilibrium oil price), linear programming (derive import supply curves), econometrics (estimate parameters of OPEC price reaction curve and rest of world crude demand/supply curves).

- Special Features: None.

Non-DOE Input Sources: None.

\section{DOE Data Input Sources:}

Forms and Publications:

- Energy Information Administration, Annual Energy Review, DOE/EIA-0384; Monthly Energy Review, DOE/EIA-0035; and International Petroleum Statistics Report, DOE/EIA-0520 (Washington, DC, annually).

- U.S. crude oil supply and demand, reference demand and supply for rest of world regions

Models and Other:

- WORLD Model
General Output Descriptions: IEM outputs include forecasted world oil price, non-OPEC production and consumption by region, and OPEC production.

\section{Computing Environment:}

- Hardware Used: IBM 3090QX

- Operating System: MVS

- Language/Software Used: FORTRAN

- Memory Requirement: $67 \mathrm{~Kb}$

- Storage Requirement: 14 tracks

- Estimated Run Time: 5 seconds

- Special Features: None.

Independent Reviews Conducted: World Oil Market component of IEM is a revised version of OMS model, which has undergone several independent reviews (e.g., International Oil Supply and Demand, Energy Modeling Forum, Stanford University, September 1991).

Status of Evaluation Efforts by Sponsor: On-going.

\section{Macroeconomic Activity Module (MAM)}

Description: MAM is comprised of three Submodules: National, Interindustry, and Regional. The National Submodule is a response surface approximation of the proprietary U.S. Quarterly Macroeconomic Model developed by Data Resources/McGraw-Hill, Inc. (DRI). The U.S. Quarterly Model is a 1,200 equation econometric specification that forecasts macroeconomic driver variables at the national level of detail.

The Interindustry Submodule is a response surface approximation of the DRI Personal Computer Input-Output (PCIO) Model. The DRI PCIO model is a detailed inputoutput representation of interindustry linkages that works in tandem with the full DRI U.S. Quarterly Model.

The Regional Submodule consists of a set of shares at the 9 Census Division level of detail developed from simulations of DRI's U.S. Quarterly Macroeconomic Model, PCIO Model, and Regional Model. The regional shares included as the Regional Submodule of MAM are used to disaggregate the national results generated by the National and Interindustry Submodules of MAM to the 9 Census Division level of detail.

Last Model Update: August 1993.

- Initial (unadjusted) import supply curves. 
Part of Another Model? National Energy Modeling System (NEMS).

Model Interfaces: MAM provides sectoral macroeconomic driver variables including housing starts, commercial floorspace, and interindustry projections to the NEMS Residential Sector, Commercial Sector, and Industrial Sector Demand Modules. MAM provides financial indicators such as interest rates to both the demand and supply modules of NEMS.

\section{Sponsor:}

- Office: Office of Integrated Analysis and Forecasting

- Division: Energy Demand and Integration Division

- Branch: International, Economic and Integrated Forecasting Branch, EI-812

- Model Contact: Kay A. Smith

- Telephone: 202-586-1455.

Documentation: Energy Information Administration, Model Documentation Report: Macroeconomic Activity Module (MAM) of the National Energy Modeling System, DOE/EIA-M065 (Washington, DC, December 1993).

Archive Media and Installation Manual(s):

- NEMS-94 (Part of the National Energy Modeling System archive package for the Annual Energy Outlook 1994, DOE/EIA-0383(94)).

- NEMS-95 (Part of the National Energy Modeling System archive package for the Annual Energy Outlook 1995, DOE/EIA-0383(95)).

Purpose: MAM links the National Energy Modeling System (NEMS) to the rest of the economy by providing industrial sector activity and macroeconomic inputs to the energy modules of NEMS. Macroeconomic variables such as Gross Domestic Product (GDP), disposable income, prices, interest rates, and unemployment drive energy demands and are important determinants of energy prices and quantities. Conversely, changes in energy supplies and prices impact GDP, prices, interest rates, and other macroeconomic variables. MAM responds to changes in energy supplies and prices to generate forecasts of approximately 100 macroeconomic variables for use in various energy modules within NEMS.

Energy System Described by Model: Domestic macroeconomic sector.

\section{Coverage:}

- Geographic: Nine Census Divisions
- Time Unit/Frequency: Annual, 1990 through 2010

- Product(s): Forecasts of domestic macroeconomic driver variables, at the national, interindustry, and regional levels of detail

- Economic Sector(s): National macroeconomic activity.

\section{Modeling Features:}

- Model Structure: MAM is composed of three Submodules: National, Interindustry, and Regional. The three submodules are executed sequentially in the order presented, and subsequent submodules build upon the results of previously executed submodules.

- Modeling Technique: The National and Interindustry Submodules of MAM are econometric response surface representations of large proprietary econometric models. The Regional Submodule of MAM is composed of shares developed from simulations of large econometric macroeconomic, industry, and regional models.

- Special Features: None.

Non-DOE Input Sources: DRI input data from the DRI U.S. Quarterly Macroeconomic Model, the DRI PCIO Model, and the DRI Regional Model.

\section{DOE Data Input Sources:}

MAM relies upon the DRI input data to generate the baseline growth path. Alternative growth paths are developed based on alternative economic driver variable growth path assumptions. DOE data is not used to develop the MAM.

General Output Descriptions: MAM provides forecasts of economic driver variables to the NEMS system.

\section{Computing Environment:}

- Hardware Used: IBM 3090; IBM-compatible personal computers

- Operating System: MVS; MS-DOS

- Language/Software Used: VS FORTRAN, Ver. 2.05

- Memory Requirement: 931Kb

- Storage Requirement: 38 tracks of an IBM 3380 disk pack

- Estimated Run Time: 3.7 CPU seconds for a 19902015 run in noniterating NEMS mode on an IBM 3090QX 
- Special Features: None.

Independent Reviews Conducted: None.

Status of Evaluation Efforts by Sponsor: None.

\section{Natural Gas Transmission and Dis- tribution Module (NGTDM)}

Description: The Natural Gas Transmission and Distribution Module (NGTDM) represents the network of pipelines and storage facilities that link suppliers (including importers) and consumers of natural gas. In conjunction with other NEMS modules, the NGTDM determines the market clearing supply and end-use quantities and prices (including border prices) of natural gas. The network representation consists of 12 intra-U.S. and 9 border transshipment nodes.

Last Model Update: November 1994.

Part of Another Model? National Energy Modeling System (NEMS).

\section{Model Interfaces: NEMS}

\section{Sponsor:}

- Office: Office of Integrated Analysis and Forecasting

- Division: Energy Supply and Conversion Division

- Branch: Oil and Gas Analysis Branch, EI-823

- Model Contact: Jim Diemer

- Telephone: 202-586-6126.

Documentation: Energy Information Administration, Model Documentation of the Natural Gas Transmission and Distribution Model (NGTDM) of the National Energy Modeling System (NEMS), DOE/EIA-M062 (Washington, DC, February 1995).

Archive Media and Installation Manual(s):

- NEMS94 (Part of the National Energy Modeling System archive package as archived for the Annual Energy Outlook 1994, DOE/EIA-0383(94)).

- NEMS95 (Part of the National Energy Modeling System archive package as archived for the Annual Energy Outlook 1995, DOE/EIA-0383(95)).

Purpose: The NGTDM is the component of the National Energy Modeling System (NEMS) that represents the midterm natural gas market. The purpose of the NGTDM is to derive natural gas supply and end-use prices and flow patterns for movements of natural gas through the regional interstate network. The prices and flow patterns are derived by obtaining a market equilibrium across the three main components of the natural gas market: the supply component, the demand component, and the transmission and distribution network that links them.

Energy System Described by Model: The NGTDM models the U.S. natural gas transmission and distribution network that links the suppliers (including importers) and consumers of natural gas, and, in so doing, determines the regional market clearing natural gas end-use and supply (including border) prices.

\section{Coverage:}

- Geographic: Demand regions are the 12 NGTDM regions, which are based on the 9 Census Divisions with Census Division 5 split further into South Atlantic and Florida, Census Division 8 split further into Mountain and Arizona/New Mexico, and Census Division 9 split further into California and Pacific, with Alaska and Hawaii handled independently.

- Time Unit/Frequency: Annually through 2010

- Product(s): Natural gas

- Economic Sector(s): Residential, commercial, industrial, electric generators and transportation.

\section{Modeling Features:}

- Model Structure: Modular; consisting of four major components; the Annual Flow Module (AFM), the Capacity Expansion Module (CEM), the Pipeline Tariff Module (PTM), and the Distributor Tariff Module (DTM)

- AFM: Simulates the natural gas price determination process by bringing together all major economic and technological factors that influence regional natural gas trade in the United States

- CEM: Develops pipeline and storage facilities capacity expansion plans, and establishes effective maximum utilization rates for each pipeline route based on a seasonal analysis of supply and demand capability

- PTM: Develops firm/interruptible tariffs for transportation and storage services provided by interstate pipeline companies

- DTM: Develops markups for distribution services provided by local distribution companies and intrastate pipeline companies. 
- Modeling Technique:

- AFM - Linear program

- CEM - Linear program

- PTM - Accounting algorithm

- DTM - Empirical process based on historical data and competing fuel prices.

- Special Features:

- Represents interregional flows of gas and pipeline capacity constraints

- Represents regional gas supplies

- Represents different types of transmission service (firm and interruptible)

- Calculates emissions associated with pipeline fuel use

- Determines the amount and the location of pipeline and storage facility capacity expansion on a regional basis

- Captures the economic trade offs between pipeline capacity additions and increases in regional storage capability

- Quantifies capital investment in capacity expansion

- Distinguishes end-use customers by type (core and noncore).

\section{Non-DOE Input Sources:}

- National Oceanographic and Atmospheric Administration (NOAA)

- Heating degree data

- National Petroleum Council, The Potential for Natural Gas in the United States (National Petroleum Council, December, 1992)

- Pipeline capacity expansion cost estimates

- OCS Report, Federal Offshore Statistics 1990, MMS91/0068

- Offshore gas production and market values

- Canadian Petroleum Association Statistical Summary
- Canadian natural gas wellhead price and production for 1990 and 1991

- Alaska Department of Natural Resources

- State of Alaska historical and projected oil and gas consumption.

DOE Data Input Sources:

Forms and Publications:

- Energy Information Administration, Form ElA-23, "Annual Survey of Domestic Oil and Gas Reserves"

- Annual estimate of gas reserves by type and State

- Energy Information Administration, Form EIA-176, "Annual Report of Natural and Supplemental Gas Supply and Disposition"

- Annual natural gas sources of supply, consumption, and flows on interstate pipeline network

- Energy Information Administration, Form EIA-860, "Annual Electric Generator Report"

- Electric utility plant type and code information, used in the classification of power plants as firm or interruptible service customers. Data from this report are also used in the derivation of historical electric generators gas demand profile (peak/offpeak splits) for core/noncore services.

- Energy Information Administration, Form EIA-767, "Steam-Electric Plant Operation and Design Report"

- Electric utility plant type and boiler information, by month, used in the classification of power plants as core or noncore service customers. Data from this report are also used in the derivation of historical electric generator's gas demand profile (peak/offpeak splits) for core/noncore customers.

- Energy Information Administration, Form EIA-759, "Monthly Power Plant Report"

- Natural gas consumption by plant code and month, used in the classification of power plants as core or noncore customers. Data from this report are also used in the derivation of electric generator's gas demand profile (peak/offpeak splits) for core/noncore customers.

- Rate case filings under Section 4 of the Natural Gas Policy Act, as submitted to FERC by each pipeline company

- Contract demand data and cost allocation by pipeline company. 
- Energy Information Administration, Annual Energy Review, DOE/EIA-0384

- Gross domestic product and implicit price deflators

- Federal Energy Regulatory Commission, Form FERC-2, "Annual Report of Major Natural Gas Companies"

- Financial statistics of major interstate natural gas pipelines

- Annual purchases/sales by pipeline (volume and price)

- Federal Energy Regulatory Commission, Form FERC-567, "Annual Flow Diagram"

- Pipeline capacity and flow information

- Energy Information Administration, Form EIA-191, "Underground Gas Storage Report"

- Base gas and working gas storage capacity and monthly storage injection and withdrawal levels by region and pipeline company

- Energy Information Administration, Capacity and Service on the Interstate Natural Gas Pipeline System 1990, DOE/EIA-0556

- Pipeline capacity and capacity reservations by customer

- Energy Information Administration, Form EIA846A/B/C, "Manufacturing Energy Consumption Survey"

- Historical natural gas consumption and average price for the industrial sector by Census region for 1988 and 1991

\section{Models and Other:}

- Energy Information Administration, National Energy Modeling System (NEMS)

- Domestic supply, imports, and demand representations are provided as inputs to the NGTDM from other NEMS modules

- Interstate Natural Gas Pipeline Data System (PIPENET)

- Inter-regional pipeline capacity

- Contract demand data.
General Output Descriptions:

- Average natural gas end-use prices and consumption levels by sector and region

- Average natural gas supply prices and production levels by region

- Compressor station emissions of $\mathrm{C}, \mathrm{CO}, \mathrm{CO}_{2}$, and $\mathrm{CH}_{4}$ and $\mathrm{VOC}$ reported as carbon by region

- Lease and plant fuel consumption by region

- Pipeline fuel consumption by region

- Pipeline capacity additions and utilization levels by region

- Storage capacity additions by region

- Capital investment in pipeline construction.

Computing Environment:

- Hardware Used: IBM 3090QX

- Operating System: MVS

- Language/Software Used: VS FORTRAN, Ver. 2.05

- Memory Requirement: 3,400Kb

- Storage Requirement: 224 tracks

- Estimated Run Time: 4.4 CPU minutes

- Special Features: NGTDM uses a proprietary software package, Optimization and Modeling Library (OML) distributed by the Ketron Management Science Division of the Bionetics Corporation. This is used to solve the two linear programs in the NGTDM and has a specially designed linear programming interface that is callable from FORTRAN.

Independent Reviews Conducted:

- Paul R. Carpenter, Ph.D., Incentives Research, Inc., Review of the Component Design Report Natural Gas Annual Flow Module (AFM) for the Natural Gas Transmission and Distribution Model (NGTDM) of the National Energy Modeling System (NEMS), Boston, MA, August 25, 1992.

- Paul R. Carpenter, Ph.D., Incentives Research, Inc., Review of the Component Design Report Capacity Expansion Model (CEM) for the Natural Gas Transmission and Distribution Model (NGTDM) of the National Energy Modeling Systems (NEMS), Boston, MA, April 30, 1993. 
- Paul R. Carpenter, Ph.D., Incentives Research, Inc., Review of the Component Design Report Pipeline Tariff Model (PTM) for the Natural Gas Transmission and Distribution Model (NGTDM) of the National Energy Modeling System (NEMS), Boston, MA, April 30, 1993.

- Paul R. Carpenter, Ph.D., Incentives Research, Inc., Review of the Component Design Report Distributor Tariff Module (DTM) for the Natural Gas Transmission and Distribution Model (NGTDM) of the National Energy Modeling System (NEMS), Boston, MA, April 30, 1993.

Status of Evaluation Efforts by Sponsor: None.

\section{Oil and Gas Supply Module (OGSM)}

Description: The Oil and Gas Supply Module (OGSM) projects the following aspects of the crude oil and natural gas industry:

- Production

- Reserves

- Drilling activity

- Natural gas imports and exports.

Last Model Update: January 1995.

Part of Another Model? National Energy Modeling System (NEMS)

\section{Model Interfaces:}

- Coal Module

- Electricity Module

- Industrial Model

- International Model

- Natural Gas Transportation and Distribution Model (NGTDM)

- Macroeconomic Module

- Petroleum Market Module.

Sponsor:

- Office: Office of Integrating Analysis and Forecasting

- Division: Energy Supply and Conversion Division
- Branch: Oil and Gas Analysis Branch, EI-823

- Model Contact: Ted McCallister

- Telephone: 202-586-4820.

Documentation: Energy Information Administration, Documentation of the Oil and Gas Supply Module (OGSM), DOE/EIA-MO63 (Washington, DC, January 1995).

Archive Media and Installation Manual(s):

- NEMS-94 (Part of the National Energy Modeling System archive package for the Annual Energy Outlook 1994), DOE/EIA-0383(94)).

- NEMS-95 (Part of the National Energy Modeling System archive package for the Annual Energy Outlook 1995), DOE/EIA-0383(95)).

Purpose: OGSM is used by the Oil and Gas Analysis Branch in the Office of Integrated Analysis and Forecasting as an analytic aid to support preparation of projections of reserves and production of crude oil and natural gas at the regional and national level. The annual projections and associated analyses appear in the Annual Energy Outlook (DOE/EIA-0383) of the Energy Information Administration. The projections also are provided as a service to other branches of the U.S. Department of Energy, the Federal Government, and non-Federal public and private institutions concerned with the crude oil and natural gas industry.

Energy System Described by Model: The OGSM forecasts oil and natural gas production activities for six onshore and three offshore regions as well as three Alaskan regions. Exploratory and developmental drilling are treated separately, with exploratory drilling further differentiated as new field wildcats or other exploratory wells. New field wildcats are those wells drilled for a new field on a structure or in an environment never before productive. Other exploratory wells are those drilled in already productive locations. Development wells are primarily within or near proven areas and can result in extensions or revisions. Exploration yields new additions to the stock of reserves and development determines the rate of production from the stock of known reserves. The OGSM also projects natural gas trade via pipeline with Canada and Mexico, as well as liquefied natural gas (LNG) trade. U.S. natural gas trade with Canada is represented by six entry/exit points and trade with Mexico by three entry/exit points. Four LNG receiving terminals are represented.

\section{Coverage:}

- Geographic: Six lower 48 onshore supply regions, three lower 48 offshore regions, and three Alaskan regions.

- Time Unit/Frequency: Annually 1990 through 2010 
- Product(s): Crude oil and natural gas

- Economic Sector(s): Oil and gas field production activities and foreign natural gas trade.

\section{Modeling Features:}

- Model Structure: Modular, containing five major components

- Lower 48 Onshore Supply Submodule

- Lower 48 Offshore Supply Submodule

- Foreign Natural Gas Supply Submodule

- Enhanced Oil Recovery Submodule

- Alaska Oil and Gas Supply Submodule

- Modeling Technique: The OGSM is a hybrid econometric/discovery process model. Drilling activities in the United States and Canada are determined by the discounted cash flow that measures the expected present value profits for the proposed effort and other key economic variables. LNG imports are projected on the basis of unit supply costs for gas delivered into the lower 48 pipeline network.

- Special Features: Can run stand-alone or within the NEMS. Integrated NEMS runs employ short-term supply functions for efficient market equilibration.

\section{Non-DOE Input Sources:}

- U.S. Geological Survey

- Alaskan oil and gas field size distributions

- Alaska facility cost by oil field size

- Alaska operating cost

- Commerce Clearing House, Inc., State Tax Guide.

- State corporate tax rate

- State severance tax rate

- U.S. Tax Code

- Federal corporate tax rate, royalty rate

- American Petroleum Institute, Joint Association Survey of Drilling Costs (1970-1990), Washington, DC.

- Onshore drilling costs
- Department of Interior, Minerals Management Service (Correspondence from Gulf of Mexico and Pacific OCS regional offices).

- Offshore drilling costs

- Offshore platform costs

- Offshore lease equipment and operating costs

- Offshore wells drilled per project

- Offshore expected recovery of oil and gas

- Energy Mines and Resources Canada, Petroleum Fiscal Systems in Canada (Third Edition - 1988).

- Canadian royalty rate

- Corporate tax rate

- Provincial corporate tax rate

- Sproule Associates Limited, The Future Natural Gas Supply Capability of the Western Canadian Sedimentary Basin (Report Prepared for Transcanada Pipelines Limited, January 1990).

- Canadian lease equipment and operating costs

- National Energy Board, Canadian Energy Supply and Demand 1990 - 2010, June 1991.

- Canadian recoverable resource base

- Canadian Petroleum Association, Statistical Handbook (1976-1990).

- Canadian wells drilled

- Canadian reserves

- National Petroleum Council, The Potential for Natural Gas in the United States: Source and Supply, Volume II (December 1992).

- Undiscovered recoverable resource base: natural gas

- Expected recovery per well: unconventional gas

- Oil Resources Panel, An Assessment of the Oil Resource Base of the United States (October 1992).

- Undiscovered recoverable resource base: crude oil 
- Department of Interior, U.S. Geological Survey/Mineral Management Services, Estimates of Undiscovered Conventional Oil and Gas Resources in the United States - A Part of the Nation's Energy Endowment (1989).

- Undiscovered recoverable resource base: regional disaggregations.

\section{DOE Data Input Sources:}

- Energy Information Administration, Costs and Indexes for Domestic Oil and Gas Field Equipment and Production Operations (1980 - 1989), DOE/EIA-0815(80-89)

- Onshore lease equipment cost

- Onshore operating cost

- Energy Information Administration

- Emissions factors

- Energy Information Administration, Capacity and Service on the Interstate Natural Gas Pipeline System 1990, DOE/EIA-0556.

- Canadian gas imports border crossing point capacities

- Energy Information Administration, Office of Oil and Gas.

- Oil and gas well initial flow rates

- Wells drilled

- Expected recovery of oil and gas per well

- Energy Information Administration, The Domestic Oil and Gas Recoverable Resource Base: Supporting Analysis for the National Energy Strategy, SR/NES/9005

\section{- Inferred reserves}

- Energy Information Administration, U.S. Crude Oil, Natural Gas, and Natural Gas Liquids Reserves (19771992), DOE/EIA-0216(77-92).

- Oil and gas reserves.

General Output Descriptions: The primary function of OGSM is to produce forecasts of crude oil, natural gas production, and natural gas imports and exports in response to price data received endogenously (within NEMS) from the Natural Gas Transmission and Distribution Model (NGTDM) and the Petroleum Market Model (PMM).
Computing Environment:

- Hardware Used: IBM 3090

- Operating System: MVS

- Language/Software Used: VS FORTRAN

- Memory Requirement: $497 \mathrm{~Kb}$

- Storage Requirement: 115 tracks

- Estimated Run Time: 8 seconds

- Special Features: None.

Independent Reviews Conducted: Independent reviews of methodology documentation of the OGSM were conducted by Gordon M. Kaufman, Sloan School of Management, Massachusetts Institute of Technology, and by John H. Schuenemeyer, Director of Statistical Laboratories, Department of Mathematical Sciences, University of Delaware, January 1994.

Status of Evaluation Efforts by Sponsor: None.

\section{Petroleum Market Module (PMM)}

Description: The Petroleum Market Model is a simulation of the U.S. petroleum industry. It includes 12 domestic crude oil production regions, 5 refining centers with full processing representations, capacity expansion capability, and gas plant liquid production, and 9 marketing regions. The heart of the model is a linear program optimization which ensures a rational economic simulation of decisions of petroleum sourcing, resource allocations, and the calculation of marginal price basis for the products. Eighteen refined products are manufactured, imported, and marketed. Seven of these products are specification blended, while the remaining 11 are recipe blended. Capacitated transportation systems are included to represent existing intra-U.S. crude oil and product shipments (LPG, clean, dirty) via pipeline, marine tanker, barge, and truck/rail tankers. The export and import of crude oil and refined products are also simulated. All imports are purchased in accordance with import supply curves. Domestic manufacture of methanol is represented as though the processing plants were a part of the refinery complexes, whereas ethanol sources are treated as merchant. Transportation is allowed for ethanol shipments to the demand region terminals for splash blending.

Last Model Update: November 1994.

Part of Another Model? National Energy Modeling System (NEMS). 
Model Interfaces: Receives information from the International, Natural Gas Transmission and Distribution, Oil and Gas Supply, Renewable Fuels, Electricity Market, Residential, Commercial, Industrial, and Transportation Modules. Delivers information to each of the modules listed above plus the Macroeconomic Module.

\section{Sponsor:}

- Office: Office of Integrated Analysis and Forecasting

- Division: Energy Supply and Conversion Division

- Branch: Oil and Gas Analysis Branch, EI-823

- Model Contact: Bruce Bawks

- Telephone: 202-586-6579

\section{Documentation:}

- Energy Information Administration, EIA Model Documentation: Petroleum Market Module of the $\mathrm{Na}$ tional Energy Modeling System (NEMS), DOE/EIAM059 (Washington, DC, December 1994).

Archive Media and Installation Manual(s):

- NEMS-94 (Part of the National Energy Modeling System archive package for the Annual Energy Outlook 1994, DOE/EIA-0383(94)).

- NEMS-95 (Part of the National Energy Modeling System archive package for the Annual Energy Outlook 1995, DOE/EIA-0383(95)).

Purpose: The PMM models domestic petroleum refining activities, the marketing of petroleum products to consumption regions, the production of natural gas liquids in gas processing plants, and domestic methanol production. The PMM is used to project petroleum product prices, refining activities, and movements of petroleum into the United States and among domestic regions. In addition, the model contains adequate structure and is sufficiently flexible to examine the impact of a wide variety of petroleum-related issues and policy options, in order to foster understanding of the petroleum refining and marketing industry, as well as determine the effects of certain policies and regulations. The PMM projects sources of supply for meeting petroleum product demand. The sources of supply include crude oil, both domestic and imported; other inputs including alcohols and ethers; natural gas plant liquids production; petroleum product imports; and refinery processing gain. In addition, the PMM estimates domestic refinery capacity expansion and fuel consumption. Product prices are estimated at the Census division level and much of the refining activity information is at the Petroleum Administration for Defense (PAD) District level.
Energy System Described by Model: Petroleum refining industry and refined products market.

\section{Coverage:}

- Geographic: Twelve domestic crude oil production regions (East Coast, Gulf Coast, Mid-Continent, Permian Basin, Rocky Mountain, West Coast, Atlantic Offshore, Gulf Offshore, Pacific Offshore, Alaska South, Alaska North, Alaska Offshore); 5 Refining Regions (PAD Districts I-V); 9 Market Regions; and the 9 Census Divisions (New England, Mid-Atlantic, East North Central, West North Central, South Atlantic, East South Central, West South Central, Mountain, Pacific).

- Time Unit/Frequency: Annual, 1990 through 2010

- Product(s): LPG, traditional motor gasoline, traditional high-oxygen motor gasoline, reformulated motor gasoline, reformulated high-oxygen motor gasoline, M85, E85, jet fuel, distillate fuel oil, highway diesel, low-sulfur residual fuel oil, high-sulfur residual fuel oil, petrochemical feedstocks, asphalt/road oil, marketable coke, still gas, other.

- Refinery Processes: crude distillation, vacuum distillation, delayed coker, fluid coker, visbreaker, fluid catalytic cracker, hydrocracker-dist, hydrocrackerresid, solvent deasphalter, resid desulfurizer, FCC feed hydrofiner, distillate HDS, naphtha hydrotreater, catalytic reformer- $450 \mathrm{psi}$, catalytic reformer- $200 \mathrm{psi}$, alkylation plant, catalytic polymerization, pen/hex isomerization, butane isomerization, MTBE (etherol), butanes splitter, dimersol, butylene isomerization, naphtha splitter, C2-C5 dehydrogenator, hydrogen plant, sulfur plant, aromatics recovery plant, lube + wax plants, FCC gasoline splitter, gas/H2 splitter, stream transfers, fuel system, steam production, power generation.

- Crude oil: Alaska low-sulfur light, Alaska mid-sulfur heavy, domestic low-sulfur light, domestic mid-sulfur heavy, domestic high-sulfur light, domestic high-sulfur heavy, domestic high-sulfur very heavy, imported lowsulfur light, imported mid-sulfur heavy, imported highsulfur light, imported high-sulfur heavy, imported high-sulfur very heavy.

- Transportation Modes: Jones Act dirty marine tanker, Jones clean marine tanker, LPG marine tanker, import tankers, clean barge, dirty barge, LPG pipeline, clean pipeline, dirty pipelines, rail/truck tankers, these cover all significant U.S. links.

\section{Modeling Features:}

- Model Structure: FORTRAN callable subroutines that update the linear programming matrix, re-op- 
timize, extract and post-process the solution results, update system variables, and produce reports.

- Modeling Technique: Optimization of linear programming representation of refinery processing and transportation which relates the various economic parameters and structural capabilities with resource constraints to produce the required product at minimum cost, thereby producing the marginal product prices in a manner that accounts for the major factors applicable in a market economy.

- Special Features: Choice of imports or domestic production of products is modeled, capacity expansion is determined endogenously, product prices include fixed and environmental costs, oxygenated and reformulated gasolines and low-sulfur diesel fuel are explicitly modeled.

Non-DOE Input Sources:

- Information Resources Inc. (IRI)

- WORLD Model data

- National Petroleum Council

- ICF Resources.

DOE Data Input Sources:

Forms and Publications:

- EIA-14, "Refiners' Monthly Cost Report"

- EIA-182, "Domestic Crude Oil First Purchase"

- EIA-782A, "Monthly Petroleum Product Sales"

- EIA-782B, "Reseller/Retailer's Monthly Petroleum Product Sales"

- EIA-782C, "Monthly Petroleum Products Sold into States for Consumption"

- EIA-810, "Monthly Refinery Report"

- EIA-811, "Monthly Bulk Terminal Report"

- EIA-812, "Monthly Product Pipeline Report"

- EIA-813, "Monthly Crude Oil Report"

- EIA-814, "Monthly Imports"

- EIA-817, "Monthly Tanker and Barge Movement"

- EIA-820, "Annual Refinery Report"

- EIA-826, "Monthly Electric Utility Sales"
- EIA-856, "Monthly Foreign Crude Oil Acquisition"

- EIA-867, "Annual Nonutility Power Producer Report"

- EIA-759, "Monthly Power Plant Report"

- FPC-423, "Monthly Report of Cost and Quantity of Fuels for Electric Plants"

- In addition to the above, information is obtained from several Energy Information Administration formal publications: Petroleum Supply Annual; Petroleum Supply Monthly; Petroleum Marketing Annual; Petroleum Marketing Monthly; Fuel Oil and Kerosene Sales, Natural Gas Annual; Natural Gas Monthly; Annual Energy Review; Monthly Energy Review; State Energy Data Report; State Energy Price and Expenditure Report.

General Output Descriptions: Output variables include petroleum product prices, petroleum supply sources, refinery fuel consumption, and capacity expansion.

Computing Environment:

- Hardware Used: IBM 3090QX

- Operating System: MVS

- Language/Software Used: VS FORTRAN, Ver. 2.05

- Memory Requirement: $4,800 \mathrm{~Kb}$

- Storage Requirement: 155 tracks on an IBM 3080 disk pack

- Estimated Run Time: 5,000 seconds in a full NEMS run (26 years)

- Special Features: PMM uses a proprietary software package, Optimization and Modeling Library (OML) distributed by the Ketron Management Science Division of the Bionetics Corporation. This is a specially designed linear programming interface that is callable from FORTRAN.

Independent Reviews Conducted: Independent reviews of the Component Design Report of the PMM were conducted by A.S. Manne, ASM Consulting Services, July 1992, and A.S. Manne, ASM Consulting Services, September 1992.

Status of Evaluation Efforts by Sponsor: None.

\section{Renewable Fuels Module (RFM)}

Description: The RFM consists of several submodules which represent the various renewable energy forms. Since 
most renewable forms of energy (i.e., biomass, conventional hydroelectricity, wind, solar, geothermal) are used to generate electricity, the interaction with the EMM-NEMS and its various submodules is important for modeling gridconnected renewable-electric applications. In the current version of the RFM, only grid-connected applications are modeled endogenously; conventional hydroelectricity is not modeled. Dispersed (off grid) renewables are modeled by demand sector. Biomass can also be used to produce liquid fuels such as ethyl alcohol (ethanol). The RFM interacts with the Petroleum Market Module (PMM), which determines refinery demand for ethanol as a gasoline blending component.

Last Model Update: November 1994.

Part of Another Model? National Energy Modeling System (NEMS).

Model Interfaces: None.

\section{Sponsor:}

- Office: Office of Integrated Analysis and Forecasting

- Division: Energy Supply and Conversion Division

- Branch: Coal, Uranium, and Renewable Fuels Analysis Branch, EI-822

- Model Contact: Perry M. Lindstrom

- Telephone: 202-586-0934

Documentation:

- Energy Information Administration, Model Documentation Renewable Fuels Module of the National Energy Modeling System, DOE/EIA-M069 (Washington, DC, April 1994).

Archive Media and Installation Manual(s):

- NEMS-94 (Part of the National Energy Modeling System archive package for the Annual Energy Outlook 94, (DOE/EIA-0383 (94)).

- NEMS-95 (Part of the National Energy Modeling System archive package for the Annual Energy Outlook 95 (DOE/EIA-0383 (95)).

Purpose: The purpose of the RFM is to define the technological and cost characteristics of renewable energy technologies for grid-connected electricity supply and to pass these characteristics to other NEMS modules for the determination of mid-term forecasted renewable energy demand. The characteristics include available energy capacity, capital costs, fixed operating costs, variable operating costs, capacity factor, heat rate, construction lead time, and fuel product price.
Energy System Described by Model:

- Municipal Solid Waste Submodule

- Byproduct energy production and consumption from the combustion of municipal solid waste.

- Wind Energy Submodule

- A hybrid of various existing and proposed horizontal-axis wind turbines. Horizontal-axis wind turbines represent over 95 percent of U.S. generating capacity.

\section{- Solar Submodule}

- Solar thermal performance is based on an intermittent central receiver system with smolten salt storage. The storage allows the electricity output to be dispatched longer than the periods at brightest sunshine, i.e., it is decoupled from the periods of high isolation. At low levels of insolation the output of the central receiver system is zero. Once the insolation exceeds a threshold level sufficient to overcome thermal losses, the daily total output is assumed to be proportional to total daily insolation. Photovoltaic performance is based on a north-south axis tracking PV system. The technology characterization assumes that rated output is reached at an insolation level of 1000 watts per square meter.

- Biofuels (Ethanol) Supply Submodule

- Agricultural sector--corn feedstock production net of byproducts; corn feedstock requirements for ethanol production; ethanol as a refinery input for gasoline blending.

- Biomass Submodule

- Currently limited to wood resources and woodfired generating plant technology information. Existing combustion boilers and projected penetration of Integrated Gasification Combined Cycle power systems are represented. Co-firing of wood and energy crops are not modeled. Wood supply curves in each of 13 supply regions are contained in the model.

\section{- Geothermal Electric Submodule}

- Hydrothermal generating system, both flash steam and binary, are represented in the GES. Direct heat and hot dry rock applications are not modeled. Resource technology and cost data are maintained in a site-specific data base and aggregated into resource supply curves, allowing geothermal units to compete in the EMM. 
Coverage:

- Municipal Solid Waste Submodule

- Geographic: 13 Electricity Supply Regions: East Central, Texas, Mid-Atlantic, Mid-America, MidContinent, Northeast, New England, Florida, Southeastern, Southwest, Western, Rocky Mountain, California and south Nevada, Alaska, and Hawaii

- Time Unit/Frequency: Annual, 1990 through 2010

- $\quad$ Product(s): Electricity

- Economic Sector(s): Electric utility sector, nonutility generators (NUGS)

\section{- Wind Energy Submodule}

- Geographic: 13 Electricity Supply Regions: East Central, Texas, Mid-Atlantic, Mid-America, MidContinent, Northeast, New England, Florida, Southeastern, Southwest, Western, Rocky Mountain, California, and South Nevada, Alaska, and Hawaii

- Time Unit/Frequency: Annual, 1990 through 2010

- Product(s): Electricity

- Economic Sector(s): Electric utility sector, nonutility generators (NUGS)

- Solar Submodule

- Geographic: 13 Electricity Supply Regions: East Central, Texas, Mid-Atlantic, Mid-America, MidContinent, Northeast, New England, Florida, Southeastern, Southwest, Western, Rocky Mountain, California and south Nevada, Alaska, and Hawaii and Pacific. Solar Thermal is modeled only for the six regions (excluding Alaska and Hawaii) west of the Mississippi.

- Time Unit/Frequency: Annual, 1990 through 2010

- Product(s): Electricity

- Economic Sector(s): Electric generation facilities.

- Biofuels (Ethanol) Supply Submodule

- Geographic: Nine Census Regions: New England, Mid-Atlantic, South Atlantic, East North Central, West North Central, East South Central, West South Central, Mountain, and
Pacific. Five PAD Districts: Atlantic Coast, North Central, South Central, Mountain and Pacific.

- Time Unit/Frequency: Annual, 1990 through 2010

- Product(s): Motor Fuel/Additives

- Economic Sector(s): Electric generation facilities.

- Biomass Submodule

- Geographic: 13 Electricity Supply Regions: East Central, Texas, Mid-Atlantic, Mid-America, MidContinent, Northeast, New England, Florida, Southeastern, Southwest, Western, Rocky Mountain, California, and south Nevada, Alaska, and Hawaii

- Time Unit/Frequency: Annual, 1990 through 2010

- Product(s): Electricity

- Economic Sector(s): Electric utility sector, nonutility generators (NUGS)

- Geothermal Electric Submodule

- Geographic: 3 Regions; Western, Rocky Mountain and California - South Nevada

- Time Unit/Frequency: Annual, 1990 through 2010

- Product(s): Electricity

- Economic Sector(s): Electric utility sector, nonutility generators.

Modeling Features:

- Municipal Solid Waste Submodule

- Model Structure: Sequential calculation of forecasted national municipal solid waste (MSW) generation, followed by derivation of regional and sector energy shares based on estimates of the percentage of MSW combusted.

- Modeling Technique: MSW Submodule Econometric estimation of municipal solid waste generation, coupled with an energy share allocation algorithm for deriving electric generation capacity and energy quantities by sector and region

- Special Features: Allows for the modeling of regional and national resource recovery efforts 


\section{- Wind Energy Submodule}

- Model Structure: Sequential calculation of available wind capacity by NERC Region, wind class and year with a deduction of that year's installed capacity from the remaining available capacity

- Modeling Technique: Accounting function of available windy land area and conversion of land area to swept rotor area and then to available generation capacity

- Special Features: Accounting for policy and/or production incentives.

\section{- Solar Submodule}

- Model Structure: The Solar Electric Submodule (SOLES) is the repository of data on solar resources, and estimates of grid-connected solar technology cost and performance characteristics. SOLES passes the fixed and variable operating costs, and capital costs to the Electricity Market Module (EMM).

- Modeling Technique: SOLES is primarily a data repository, with the ability to lower estimated technology capital costs as the technology penetrates the market.

- Special Features: SOLES contains data and estimates for both solar thermal (central receiver) and photovoltaic (flat plate crystalline silicon) technologies. Solar thermal technologies are modeled only in the six NERC regions west of the Mississippi, where direct normal solar conditions are best.

\section{- Biomass Submodule}

- Model Structure: Sequential calculation of available wood capacity by electricity supply region and year. Represents current wood-fired units plus new additions of Integrated Gasification Combined Cycle systems after 2000.

- Modeling Technique: Cost and performance parameters allowed to compete with other fuels and technologies in EMM. Regional wood supply data incorporated into variable costs in deriving levelized costs.

- Special Features: Accounting for policy and/or production incentives.

\section{- Geothermal Electric Submodule}

- Model Structure: Aggregation of geothermal site data into supply curves, sequential calculation of geothermal generating capacity by NERC Region and year and decrementing resources base.

- Modeling Techniques: Cost and performance parameters allowed to compete with other fuels and technologies in EMM. Geothermal supply data limited by an exogenous "cap" to prevent averaging of the entire cost spectrum. Installation of capacity at each site is controlled to a predetermined schedule consistent with industry practices.

- Special Features: Accounting for policy and/or production incentives.

\section{Non-DOE Input Sources:}

\section{- Municipal Solid Waste Submodule}

- Franklin Associates, data prepared for the Environmental Protection Agency

- National annual quantity of municipal solid waste generated

- Forecasted annual percentages of municipal solid waste combusted

- Government Advisory Associates, Resource Recovery Yearbook and Resource Recovery Database

- Plant-specific electricity generation, Btu energy content of MSW

- Plant locations and energy-consuming sectors

- Electric Power Research Institute, (TAG) Technical Assessment Guide, 1993.

- Capital cost; fixed and variable operation and maintenance costs

- Plant capacity factor

- Wind Energy Submodule

- Princeton Economic Research, Incorporated (PERI)

- WNDSLICE preprocessing program

- Science Applications International Corporation (SAIC)

- Cost and performance data as prepared for the National Energy Strategy project 
- Electric Power Research Institute, Technical Assessment Guide (TAG), 1993.

- Solar Submodule

- California Energy Commission

- Capital costs for solar thermal and photovoltaic technologies

- Fixed O\&M costs

- Variable O\&M costs

- Construction period

- Construction fraction distribution

- Energy Policy Act of 1992

- Production policy incentive

- IRS Tax Code

- 10-percent investment tax credit

- National Solar Radiation Database

- Regional Insolation

- Biofuels (Ethanol) Supply Submodule

- Omnibus Reconciliation Act of 1990

- 54 cents per gallon subsidy for ethanol blenders

- Marland \& Turhollow, 1991

- Quantity of energy needed for process conversion

- Quantity of fuel used in the production of feedstocks

- United States Department of Agriculture (USDA) - Report 585

- Capital and operating costs for conversion technologies

- United States Department of Agriculture (USDA) (ARIMS)

- Feedstock cost data

- A. Turhollow, B. English

- ARIMS outputs
- Biomass Submodule

- U.S. Department of Agriculture, Forest Service Products Laboratory, Madison, WI.

- Marginal Cost Supply Curves for Utilizing Forest Waste Wood in the United States." McQuillen, A. et. al. Unpublished manuscript, 1984.

- Cost and quantity data for waste wood, including logging residues and excess whole trees

- National Renewable Energy Laboratory, Golden, CO.

- "Cost and Performance Potential of Advanced Integrated Biomass Gasification Combined Cycle Power Systems, Craig, K.R.; Mann, M.K.; and Bain, R.L. 1994.

- Cost and performance values for IGCC technology

- Geothermal Electric Submodule

- None.

\section{DOE Data Input Sources:}

- Municipal Solid Waste Submodule - None.

- Wind Energy Submodule

- Forms and Publications: Energy Information Administration, Annual Energy Review 1991, DOE/EIA-0384(91), (Washington, DC, June 1992)

Models and Other: Pacific Northwest Laboratory, Report Nos. PNL-7789, DOE/CH10093-4, and PNL-3195

- Solar Submodule

Models and Other:

- EE/RE Technology Characterizations

- Capital costs for PV technology

- Fixed O\&M costs for PV technology

- Variable O\&M costs for PV technology

- Prototype system efficiencies

- Construction period for PV technology

- Construction fraction distribution for PV technology 
- Biofuels (Ethanol) Supply Submodule - None.

- Biomass Submodule

- Oak Ridge National Laboratory, Oak Ridge, Tennessee. "Data and Sources - Biomass Supply, A. Turhollow et. al. Unpublished report, 1993.

- Cost and quantity data for mill residues and other wood

\section{- Geothermal Electric Submodule}

- Energy Information and the Geothermal Energy Division, Office of Energy Efficiency and Renewable Energy, U.S. Department of Energy, Supply of Geothermal Power from Hydrothermal Sources, Susan Petty, et. al. Solana Beach, CA. Study done for U.S. DOE, June 1991.

- Cost and quantity data for individual geothermal sites.

General Output Descriptions: The RFM is structured principally to provide the EMM with technology and cost data for central station electric generation facilities. The exceptions include the MSW Submodule, which forecasts MSW energy consumption for several end-use demand models along with the EMM, and the Biofuels Supply Submodule, which provides ethanol supply curves for the Petroleum Market Module (PMM).

Computing Environment:

- Hardware Used: IBM 3090QX

- Operating System: MVS

- Language/Software Used: VS FORTRAN, Ver. 2.05

- Memory Requirement: $46 \mathrm{~Kb}$

- Storage Requirement: 51 tracks

- Estimated Run Time: Municipal Solid Waste Submodule - 0.02 seconds; Wind Energy Submodule - .06 seconds; Solar Submodule -.03 seconds; Biomass (Ethanol) Submodule - 0.02 seconds

- Special Features: None.

Independent Reviews Conducted: None.

Status of Evaluation Efforts by Sponsor: None.

\section{Residential Sector Demand Module (RSDM)}

Description: The NEMS Residential Sector Demand Module is an integrated dynamic modeling system that projects residential energy demand by service, fuel, and Census Division. The modeling methodology is based on accounting principles and considers important issues related to consumer behavior. Housing and equipment stocks are tracked over the forecast period for seven major services. The major services considered are space heating, space cooling, water heating, cooking, clothes drying, refrigeration, and freezers. A logit function is used to estimate market shares of each equipment technology within each major service based on either the installed capital and operating costs or the life-cycle cost. Lighting choices are modeled by assuming market shares for three specific lighting technologies in specific forecast years. Miscellaneous appliance consumption is calculated as a function of Unit Energy Consumption (UEC), a measure of energy intensity developed from the Residential Energy Consumption Survey (RECS) data base.

Last Model Update: November 1994.

Part of Another Model? National Energy Modeling System (NEMS).

Model Interfaces: The NEMS Residential Sector Demand Module receives U.S. population and housing construction input data from the NEMS Macroeconomic Activity Module (MAM). Outputs in the form of quantities of fuel demanded in the residential sector are provided to the NEMS Integrating Module and the NEMS Supply Modules: Electricity Market Module, Petroleum Market Module, and Natural Gas Supply Module.

\section{Sponsor:}

- Office: Office of Integrated Analysis and Forecasting

- Division: Energy Demand and Integration Division

- Branch: Energy Demand Analysis Branch, EI-813

- Model Contact: John H. Cymbalsky

- Telephone: $202-586-4815$.

Documentation: Energy Information Administration, Model Documentation Report: Residential Sector Demand Model of the National Energy Modeling System, DOE/EIAM067(95), Washington, DC, March 1995).

Archive Media and Installation Manual(s):

- NEMS-94 (Part of the National Energy Modeling System archive package for the Annual Energy Outlook 1994, DOE/EIA-0383 (94)). 
- NEMS-95 (Part of the National Energy Modeling System archive package for the Annual Energy Outlook 1995, DOE/EIA-0383 (95)).

Purpose: RSDM generates mid-term forecasts of residential sector energy demand for the period 1990 through 2010. The model facilitates policy analysis of energy markets, technological changes and regulatory developments.

Energy System Described by Model: U.S. residential sector energy consumption

\section{Coverage:}

- Geographic: Nine Census Divisions: New England, Mid-Atlantic, East North Central, West North Central, South Atlantic, East South Central, West South Central, Mountain, and Pacific

- Time Unit/Frequency: Annual, 1990 through 2010 in the current mid-term horizon

- Product(s): Fuel consumption including: electricity, natural gas, distillate, liquefied petroleum gas, kerosene, geothermal, wood, solar thermal, and coal. Energy consumption per household. Equipment stock and efficiency.

- Economic Sector(s): Domestic residential sector

- Services: Space heating, space cooling, water heating, cooking, clothes drying, refrigeration, freezers, lighting, other electric appliances, other appliances, and secondary space heating

Housing Types: Single-Family, Multifamily, and Mobile Homes.

Modeling Features:

- Model Structure: Sequential algorithm composed of housing and equipment stock flow algorithms, technology choice algorithm, housing shell integrity algorithm, end-use consumption, and emissions calculations

- Modeling Technique: Housing and equipment stock turnover are modeled using linear decay functions. Market shares for each type of equipment choice are based on a logit function employing installed capital costs and operating costs. Unit energy consumption estimates, fuel prices, and equipment market shares are user inputs that drive the calculation of final enduse consumption.

- Special Features: Technology choice logit function has the ability to use installed capital, and operating costs or life-cycle costs to determine new market shares.
Non-DOE Input Sources:

- U.S. Bureau of the Census, Current Construction Report-Series C25 Characteristics of New Housing: 1993 (Washington, DC, 1994).

- New housing and base year market shares for some services and equipment types

- Gas Appliance Manufactures Association, Consumers' Directory for Certified Efficiency Ratings, 1991

- Lawrence Berkeley Laboratory, Baseline Data for the Residential Sector and Development of a Residential Forecasting Database, 1994.

- Residential equipment technical characterization data

- The major data input sources are discussed in the Appendix of the documentation. Appendix C provides additional bibliographic citations of data sources used in the Residential Sector Demand Module.

\section{DOE Data Input Sources:}

- U.S. Department of Energy, Energy Information Administration, Residential Energy Consumption Survey, 1990.

- Base-year market shares for services and equipment types

- Base-year housing stock

- Unit energy consumption values (UEC's). The major data input sources are discussed in the Appendix of the documentation. Appendix $C$ provides additional bibliographic cites of data sources used in the Residential Sector Demand Module.

General Output Descriptions: Forecasted residential sector energy consumption by fuel type, service and Census Division is the primary module output. The module also forecasts housing stock, energy consumption per household, and airborne emissions by pollutant for the six pollutant categories listed previously. In addition, the module is capable of producing a disaggregated forecast of appliance stock and efficiency. The types of appliances included in this forecast are:

- Heat pumps (electric, natural gas, and geothermal)

- Furnaces (natural gas and distillate)

- Other heating appliances (electric, LPG, kerosene, and wood stoves) 
- Central air-conditioners

- Room air-conditioners

- Water heaters (electric, natural gas, distillate, LPG, and solar thermal)

- Ranges/Ovens (electric, natural gas, and LPG)

- Clothes dryers (electric and natural gas)

- Refrigerators

- Freezers.

\section{Computing Environment:}

- Hardware Used: IBM 3090QX

- Operating System: MVS

- Language/Software Used: VS FORTRAN, Ver. 2.05

- Memory Requirement: 7,000Mb

- Storage Requirement: 35 tracks

- Estimated Run Time: .08 seconds CPU time per iteration

- Special Features: None.

Independent Reviews Conducted: Independent expert reviews of the Residential Sector Component Design Report, (May 28, 1992) were conducted by Inderjit Kundra, Office of Statistical Standards; Fred Joutz, Office of Statistical Standards; Ronald D. Sands, Battelle Pacific Northwest Laboratory, James E. McMahon, Lawrence Berkeley Laboratory; and Francis X. Johnson, Lawrence Berkeley Laboratory.

Status of Evaluation Efforts by Sponsor: None.

\section{Transportation Sector Module (TRAN)}

Description: TRAN incorporates an integrated modular design which is based upon economic, engineering, and demographic relationships that model transportation sector energy consumption at the nine Census Division-level of detail. TRAN comprises the following components: Light Duty Vehicles, Light Duty Fleet Vehicles, Freight Transport (truck, rail, and marine), Aircraft, Miscellaneous Transport (military, mass transit, and recreational boats), and Transportation Emissions. The model provides sales estimates of 2 conventional and 14 alterna- tive fuel light-duty alternative fuel vehicles, and consumption estimates of 12 fuels.

Last Model Update: December 1994.

Part of Another Model? National Energy Modeling System (NEMS).

Model Interfaces: Receives inputs from the Electricity Market Module, Oil and Gas Market Module, Renewable Fuels Module, and the Macroeconomic Activity Module. Model outputs are provided to the Integrating Module, which then sends them back to the supply modules.

Sponsor:

- Office: Office of Integrated Analysis and Forecasting

- Division: Energy Demand and Integration Division

- Branch: Energy Demand Analysis Branch, EI-813

- Model Contact: David M. Chien

- Telephone: 202-586-3994.

Documentation:

- Energy Information Administration, Model Documentation Report: Transportation Sector Model of the National Energy Modeling System, DOE/EIA-M070 (Washington, DC, March 1994).

Archive Media and Installation Manual(s):

- NEMS-94 (Part of the National Energy Modeling System archive package for the Annual Energy Outlook 1994, DOE/EIA-0383(94)).

- NEMS-95 (Part of the National Energy Modeling System archive package for the Annual Energy Outlook 1995, DOE/EIA-0383(95)).

Purpose: TRAN generates mid-term forecasts of transportation sector energy consumption. The transportation model facilitates policy analysis of energy markets, technological development, environmental issues, and regulatory development as they impact transportation sector energy consumption.

Energy System Described by Model: Domestic transportation sector energy consumption.

\section{Coverage:}

- Geographic: Nine Census Divisions: New England, Mid Atlantic, East North Central, West North Central, South Atlantic, East South Central, West South Central, Mountain, Pacific 
- Time Unit/Frequency: Annually, 1990 through 2010

- Product(s): Motor gasoline, aviation gasoline, diesel/distillate, residual oil, electricity, jet fuel, LPG, CNG, methanol, ethanol, hydrogen, lubricants

- Economic Sector(s): Forecasts are produced for personal travel, freight trucks, railroads, domestic and international marine, aviation, mass transit, and military use.

\section{Modeling Features:}

- Model Structure: Light-duty vehicles are classified according to the six EPA size-classes for cars and light trucks. Freight trucks are divided into light-duty, medium-duty, and heavy-duty size classes. The air transport module contains both wide and narrow-body aircraft. Rail transportation is composed of freight rail and three modes of personal rail travel, commuter, intercity, and transit. Shipping is divided into domestic and international ships.

- Modeling Technique: Module-dependent: Econometrics for passenger travel, aviation, and new vehicle market shares; exogenous engineering and judgement for MPG, aircraft efficiency, and various freight characteristics; and structural for light-duty vehicle and aircraft capital stock estimations.

- Special Features: The Transportation Sector Model has been created to allow the user to change various exogenous and endogenous input levels. The range of policy issues that the transportation model can evaluate are: fuel taxes and subsidies, fuel economy levels by size class, CAFE levels, vehicle pricing policies by size class, performance demand for vehicle performance within size classes; fleet vehicle sales by technology type, alternative-fuel vehicle sales shares, the Energy Policy Act, Low Emission Vehicle Program, VMT reduction, and greenhouse gas emissions levels.

\section{Non-DOE Input Sources:}

- Oak Ridge National Laboratory, Energy Data Book, various years

- Oak Ridge National Laboratory, Fleet Vehicles in the U.S. (1992)

- Oak Ridge National Laboratory, Light-Duty Vehicle $M P G$ and Market Report, various years

- Federal Aviation Administration, $F A A$ Aviation Forecasts: Fiscal Years 1993 - 2004, various years

- Department of Commerce, Bureau of the Census, Truck Inventory and Use Survey 1987.
- California Air Resources Board, Proposed Regulations for Low-Emission Vehicles and Clean Fuels, Staff Report (August 13, 1990).

- David S. Bunch, Mark Bradley, Thomas F. Golob, Ryuichi Kitamura, Gareth P. Occhiuzzo, Demand for Clean-Fuel Personal Vehicles in California: A DiscreteChoice Stated Preference Survey, Presented at the Conference on Transportation and Global Climate Change: Long Run Options, Asilomar Conference Center, Pacific Grove, California, August 26, 1991.

- National Energy Accounts

- Federal Highway Administration Highway Statistics various years

- Department of Transportation Air Travel Statistics

- Air Transport Association of America

- 1990 Air Travel Survey.

DOE Data Input Sources:

Forms and Publications:

- Energy Information Administration, Form EIA876A/E, "Residential Transportation Energy Consumption Survey" (RTECS).

Models and Other:

- U.S. Department of Energy, Office of Policy, Planning and Analysis, Assessment of Costs and Benefits of Flexible and Alternative Fuel Use in the U.S. Transportation Sector, Technical Report Ten: Alternative-Fuel Requirements, 1992.

- State Energy Data System (SEDS) 1991, May 1993.

General Output Descriptions: The Transportation Model produces forecasts of travel demand, disaggregated by Census Division, vehicle and fuel type, conventional and alternative vehicle technology choice; vehicle stock and efficiency; energy demand, by vehicle and fuel type; and emissions of specific airborne pollutants.

\section{Computing Environment:}

- Hardware Used: IBM 3090QX

- Operating System: MVS

- Language/Software Used: VS FORTRAN, Ver. 2.05

- Memory Requirement: $2,800 \mathrm{Mb}$

- Storage Requirement: 450 tracks 
- Estimated Run Time: 2 minutes for a 1990 through 2015 run on noniterating NEMS Mode on IBM 3090 mainframe

\section{- Special Features: None.}

Independent Reviews Conducted: Independent Expert Review of the Transportation Sector Component Design Report, conducted by David L. Greene, Oak Ridge National Laboratory, June 1992.

Status of Evaluation Efforts by Sponsor: None.

\section{"WORLD" Reference Model (WOR)}

Description: The WORLD model is a linear programming model which simulates the operation of the world regional petroleum industry based on user-specified assumptions regarding the time horizon and scenario of interest. The WORLD model simulates regional effects. Insights at the level of individual countries or refinery type can be obtained but only where the model has been appropriately disaggregated.

\section{Last Model Update: NA}

Part of Another Model? No.

Model Interfaces: International Energy Module and Petroleum Market Module of the NEMS.

\section{Sponsor:}

- Office: Office of Integrated Analysis and Forecasting

- Division: Energy Demand and Integration Division

- Branch: International, Economics and Integrated Forecasting, EI-812

- Model Contact: Dan Butler

- Telephone: 202-586-9503

Documentation: Energy Information Administration, WORLD Oil Refining Logistics Demand Model, DOE/EIAM058 (Washington, DC, January 1994).

Archive Media and Installation Manual(s): WORLD is not archived as part of the of the NEMS-95 due to the proprietary nature of the model code.

\section{Purpose:}

- The WORLD system was developed to meet five design goals:
- Realism under a wide range of business-as-usual (BAU) and non-BAU scenarios

- Scope to address forward issues, horizons, and technical challenges

- Flexibility to address different needs and applications

- Performance and portability across different computers.

Energy System Described by Model: World petroleum industry.

\section{Coverage:}

- Geographic: Regional Disaggregation

- Representation of the world's major regions with flexibility to redefine regions to meet specific needs

- Flexibility to create refining sub-regions, e.g., to distinguish different classes of refiners

- Time Unit/Frequency: A snapshot of an average day in a year, quarter, or month

- Product(s): Crude oils and refined products

- Economic Sector(s): Petroleum refining and transportation.

\section{Modeling Features:}

- Model Structure: WORLD is a linear programming model which simulates the operation of the world-wide petroleum industry based on user-specified assumptions regarding the time horizon and scenario of interest.

- Modeling Technique: Linear programming

- Special Features: None.

Non-DOE Input Sources: Various industry sources for refinery processes, crude oil assays, and refined product specifications.

\section{DOE Data Input Sources:}

Energy Information Administration, International Energy Annual, DOE/EIA-0219 (Washington, DC, annually).

General Output Descriptions: WORLD outputs physical information, refining and market economic information, and regional and global economic information.

- Integration of industry elements 
Computing Environment:

- Hardware Used: IBM-compatible personal computer with math coprocessor

- Operating System: MS-DOS 5.0

- Language/Software Used: OMNI for matrix creation, CPLEX for optimization

- Memory Requirement: $24 \mathrm{Mb}$ RAM

- Storage Requirement: $15 \mathrm{Mb}$

- Estimated Run Time: 90 minutes $(48650 \mathrm{MHz})$

- Special Features: None.

Independent Reviews Conducted: None.

Status of Evaluation Efforts by Sponsor: None.

\section{Other EIA Models}

\section{Disruption Impact Simulator Model (DIS)}

Description: The Disruption Impact Simulator (DIS) is a Lotus 1-2-3 spreadsheet model that forecasts the world oil price and key economic effects of an oil supply disruption. Given a set of user-defined assumptions, such as inventory behavior and fuel switching potential, the DIS estimates the world oil price, losses in the Gross National Product (GNP), increases in the inflation rate, terms of trade losses, and national end use prices for gasoline and heating oil for four quarters. By using easy to understand interface screens, the user has more interaction with the DIS than most other spreadsheet models. Senior Department of Energy officials have been impressed with the capability of the DIS. Not only can the DIS handle an oil disruption of any size, but the user can select from over 20 geographic areas to disrupt. The model also estimates whether the International Energy Program (IEP) would be activated by the International Energy Agency (IEA), and if so, what the effect would be on several IEA countries, including the United States.

Last Model Update: April 1995.

Part of Another Model? No.

Model Interfaces: None directly. Some inputs come from the Short-Term Integrated Forecasting System.

\section{Sponsor:}

- Office: Energy Markets and End Use
- Division: Energy Markets and Contingency Information

- Branch: Short-Term Forecasting and Contingency, EI-621

- Model Contact: Douglas MacIntyre

- Telephone: 202-586-1831.

Documentation: Energy Information Administration, Model Documentation for the Disnuption Impact Simulator (DIS) (Washington, DC, December 28, 1989).

Archive Media and Installation Manual(s):

- DIS2Q95.WK1 is available on a diskette from the model contact.

- READ.ME describes any installation requirements and is available on a diskette.

- Archived as part of the WEPS94 model in support of International Energy Outlook 1994.

Purpose: The DIS estimates world oil prices and key economic effects of an oil supply disruption for up to six quarters. The model is generally used in assessing the impacts of an oil supply disruption given a user-specified set of assumptions.

Energy System Described by Model: The model describes world oil supply and demand, as well as world prices in the event of an oil supply disruption.

\section{Coverage:}

- Geographic: Countries in the International Energy Agency, the Organization of Petroleum Exporting Countries, Centrally Planned Economies, and developing countries

- Time Unit/Frequency: Any six quarters, although generally used for the most current six quarters

- Product(s): Crude oil and petroleum products

- Economic Sector(s): Generally, most results are limited to the market economies of the world.

Modeling Features:

- Model Structure: Equilibrium simulation

- Modeling Technique: Accounting of supply and demand changes from business-as-usual (BAU) data.

- Special Features: Specially designed interface screen simplify the use of this model. Automatic generation 
of reports and graphs also simplify analysis of the model results.

Non-DOE Input Sources: None.

DOE Data Input Sources:

Forms and Publications:

- Energy Information Administration, Short-Term Energy Outlook, DOE/EIA-0202 (Washington, DC).

- BAU supply and demand

- Energy Information Administration, International Petroleum Statistics Report.

- World refinery gains and discrepancies

Models and Other:

- None.

General Output Descriptions: Given a set of assumptions and an oil supply disruption, the DIS generates four different reports and graphs. The reports are: (1) Disruption Summary, (2) World Oil Shortfalls, (3) World Oil Balance, and (4) U.S. Impact Report. The graphs generated are: (1) World Oil Prices, (2) U.S. GNP Losses, (3) U.S. Gasoline Prices, and (4) IEA Allocation Rights/Obligations.

Computing Environment:

- Hardware Used: IBM-compatible personal computer

- Operating System: MS-DOS

- Language/Software Used: Lotus 1-2-3, Ver. 2.0 or greater

- Memory Requirement: $250 \mathrm{~Kb}$

- Storage Requirement: 300 bytes

- Estimated Run Time: Solving the model takes under 10 seconds. Specifying assumptions for a run can take a couple of minutes.

- Special Features: Fast turnaround and user interface.

Independent Reviews Conducted: None.

Status of Evaluation Efforts by Sponsor: Extensive internal review.

\section{Distillate Market Model (DMM)}

Description: The DMM performs a short-term (6 to 9 month) forecast of demand and price in the U.S. No. 2 fuel oil market. The model also calculates the end-of-month stock level. The model is used to analyze certain market behavior assumptions or market shocks and to determine their effect on market price, demand and stocks.

Last Model Update: NA

Part of Another Model? None.

Model Interfaces: The DMM uses inputs from STIFS, from which it obtains economic and refinery data.

Sponsor:

- Office: Office of Oil and Gas

- Division: Petroleum Marketing Division

- Branch: Publications and Analysis, EI-432

- Model Contact: John Zyren

- Telephone: 202-586-6405.

Documentation: Energy Information Administration, Model Documentation of the Distillate Activity Market Model, DOE/EIA-M056 (Washington, DC, September 1993).

Archive Media and Installation Manual(s): Archived on floppy disks.

Purpose: DMM was developed to provide support for the Distillate Outlook article published in the Winter Fuels Report and the Petroleum Marketing Monthly. The DMM assesses the market response to alternative market scenarios and/or shocks. The model relies on the STIFS mid-world oil price case for values of economic and refinery behavior variables to define a base-line and then uses assumptions on different possible market disturbances to assess their effects on a monthly basis. The DMM provides a framework to calculate stock levels from the estimated demand and price variables.

Energy System Described by Model: No. 2 distillate demand, retail prices and end-of-month stock levels.

Coverage:

- Geographic: National

- Time Unit/Frequency: Monthly

- Product(s): Retail No. 2 Distillate Fuel Oil

- Economic Sector(s): Retail No. 2 Distillate Market 
Modeling Features:

- Model Structure: Multi-equation model

- Modeling Technique: Ordinary least squares, with correction for autocorrelation

- Special Features: None.

\section{Non-DOE Input Sources:}

- Data Resources, Inc. (DRI) database, data from Bureau of Economic Analysis and Bureau of Labor Statistics

- Macroeconomic production, and price index variables

- U.S. Department of Commerce, National Oceanographic and Atmospheric Administration, Data Source DRD 964

- Actual and normal statewide monthly heating degree day values.

\section{DOE Data Input Sources:}

Forms and Publications:

- Energy Information Administration, Petroleum Supply Annual, DOE/EIA-0340 and Petroleum Supply Monthly, DOE/EIA-0109 (Washington, DC, monthly).

- No. 2 distillate stocks and product supplied

- Energy Information Administration, Petroleum Marketing Annual, DOE/EIA-0487 and Petroleum Marketing Monthly, DOE/EIA-0380 (Washington, DC, monthly).

- Average imported crude oil refiner's acquisition costs, residential No. 2 fuel oil prices.

Models and Other:

- Energy Information Administration, Short-Term Integrated Forecasting System

- Forecasts of economic and refinery variables.

General Output Descriptions: DMM is used to generate very short-term (up to 9 months), monthly forecasts of U.S. demand, price and stock levels of retail No. 2 distillate.

\section{Computing Environment:}

- Hardware Used: IBM-compatible personal computer

- Operating System: MS-DOS
- Language/Software Used: Micro-TSP, Ver. 7.01 or higher

- Memory Requirement: $640 \mathrm{~Kb}$

- Storage Requirement: $640 \mathrm{~Kb}$

- Estimated Run Time: 30 seconds calculation time on an 80386 PC operating under DOS 5

- Special Features: None.

Independent Reviews Conducted: None.

Status of Evaluation Efforts by Sponsor: On-going. Annual revisions will be made based on needs of users.

\section{International Nuclear Model - Personal Computer (PCINM)}

Description: The Personal Computer International Nuclear Model (PCINM) is a deterministic model used by the Energy Information Administration (EIA) to project domestic and international nuclear energy requirements. The EIA uses the PCINM to project aggregate spent fuel discharges, fuel cycle requirements, on-line and year-end capacities, and electricity generation for domestic and foreign nuclear reactors on an annual basis, using a simple accounting technique. PCINM can be used to produce projections for any country in the world for any specified time period. Currently eight (8) different country groups are being projected through the year 2010 . To produce the forecasts, EIA develops a set of operational assumptions for capacity factors, full power days, reactor size, and reload quantities. These assumptions are derived statistically from historical operating data and from utilities' projected fuel management schemes and are incorporated into fuel management plans. Estimates of nuclear fuel cycle trends are determined by surveying utilities, fuel vendors, and other industry experts.

Last Model Update: July 1992.

Part of Another Model? No.

Model Interfaces: None.

Sponsor:

- Office: Coal, Nuclear, Electric and Alternate Fuels

- Division: Analysis and Systems Division

- Branch: Nuclear Fuel Cycle Branch, EI-531

- Model Contact: Diane L. Jackson

- Telephone: 202-254-5536. 


\section{Documentation:}

- Nuclear Fuel-Cycle Requirements System, Benchmarking Procedures Report; Z, Inc. (Washington, DC, January 15, 1992).

- Nuclear Fuel-Cycle Requirements System, Program Specifications for Fuel Cycle Requirements Forecasting; Z, Inc. (Washington, DC, August 23, 1991).

- Nuclear Fuel-Cycle Requirements System, Phase I Development; Z, Inc. (Washington, DC, March 1, 1991).

- International Nuclear Model: Volume 1, Model Overview; David A. Andress (Washington, DC, March 1985).

- Intemational Nuclear Model: Volume 2, Database Relationships; David A. Andress (Washington, DC, April 1985).

- Intemational Nuclear Model: Volume 3, Program Description; David A. Andress (Washington, DC, June 1985).

- International Nuclear Model Personal Computer (PCINM), Z, Inc., DOE/EIA-M051(92), (Washington, DC, September 1993).

Archive Media and Installation Manual(s):

- PCINM92 - for the World Nuclear Capacity and FuelCycle Requirements

- PCINM93 - for the World Nuclear Capacity and FuelCycle Requirements.

Purpose: PCINM provides fuel-cycle forecasts for uranium and enrichment service requirements, spent fuel discharges and annual nuclear electricity generation projections and on-line and year-end capacities.

Energy System Described by Model: Electricity generation by nuclear-powered units.

\section{Coverage:}

- Geographic: Any country or predefined country group (user specified, limited to data availability)

- Time Unit/Frequency: Specified by user or on an annual basis, no limitation on number of years

- Product(s): Nuclear fuel-cycle requirements, spent fuel discharges, electrical generation projections, and on-line and year-end capacities
- Economic Sector(s): Electric commercial utility sector with emphasis on the nuclear fuel-cycle requirements.

\section{Modeling Features:}

- Model Structure: Deterministic model based upon factual input data and scenario assumptions. Derives cycle-by-cycle, reactor-by-reactor interim values to determine final annual projections of uranium and enrichment requirements, spent fuel discharges, electricity generation, and on-line and year-end capacities.

- Modeling Technique: Accounting method on an annual basis--there is only one correct solution for a given set of input data and selected scenario assumptions.

- Special Features: Flexible analysis of fuel management capabilities.

\section{Non-DOE Input Sources:}

- Nuclear Assurance Corporation, Norcross, GA

- U308 Status Report; Enrichment Status Report; Discharge Fuel/Reprocessing Report

- Foreign core size, capacity factors, full power days, reload fraction, U235 enrichment assay

- Nuclear Regulatory Commission

- Domestic reactor capacity factors, nominal capacity, reload fraction and U235 enrichment assay

- Nucleonics Week, Washington, DC

- Foreign capacity factors.

DOE Data Input Sources:

Forms and Publications:

- Department of Energy, Energy Information Administration, Form RW-859, "Nuclear Fuel Data"

- Electric utility survey data used to set starting inventory levels of spent fuel

- Survey data used to determine and update reactor near-term operating characteristics

- Department of Energy, Office of Nuclear Energy

- Tails assay estimates 
Models and Other:

- Energy Information Administration, World Integrated Nuclear Evaluation System, WINES

- Projects long-term nuclear generating capacities worldwide.

General Output Descriptions: Reports and report files identifying spent fuel, fuel-cycle requirements, and electric generation, on-line and year-end capacities, annualized by country or domestic region by reactor type over a userspecified projection period.

Computing Environment:

- Hardware Used: IBM-compatible 386, VGA monitor, $40 \mathrm{Mb}$ hard drive, math coprocessor, printer

- Operating System: DOS 3.3 or higher

- Language/Software Used: CLIPPER (version 5.01), dBASE IV, C

- Memory Requirement: 7Mb RAM

- Storage Requirement:

- For Databases, Program Library, and CLIPPER EXE files $=2 \mathrm{Mb}$

- For temporary and memory files = TBD upon final benchmarking results

- Estimated Run Time: approximately 4 minutes per scenario

- Special Features: None.

Independent Reviews Conducted: None.

Status of Evaluation Efforts by Sponsor: On-going.

\section{Levelized Nuclear Fuel Cycle Cost Model (LNFCC-PC)}

Description: LNFCC-PC computes an electric utility's levelized nuclear fuel cost. The code computes quantities of fuel-cycle services and levelized direct costs, which include the carrying charges accounting for the time value of money. All fuel-cycle services from natural uranium purchased through waste disposal are covered.

Last Model Update: April 1986.

Part of Another Model? No

Model Interfaces: As required for particular application.
Sponsor:

- Office: Office of Integrated Analysis and Forecasting

- Division: Energy Supply and Conversion Division

- Branch: Coal, Uranium and Renewable Fuels Analysis Branch, EI-822

- Model Contact: Laurence Sanders

- Telephone: 202-586-2049.

Documentation:

- Energy Information Administration, Levelized Nuclear Fuel-Cycle Cost Model User's Guide, MDR/ES/81 (Washington, DC, June 1982).

- Energy Information Administration, Levelized Nuclear Fuel-Cycle Cost (LNFCC-PC) Lotus 1-2-3 Spreadsheet Documentation, Installation and Operating Instructions, Laurence Sanders (Washington, DC, April 1986).

Archive Media and Installation Manual(s):

- LNFCC86 - Annual Energy Outlook 1986

- LNFCC90 - Annual Energy Outlook 1990.

Purpose: LNFCC-PC computes nuclear fuel cost, given uranium prices, fuel processing prices, tails assays, and reactor operations data.

Energy System Described by Model: LNFCC-PC covers the entire nuclear fuel cycle.

Coverage:

- Geographic: Constrained to light water reactors (LWRs) United States and foreign

- Time Unit/Frequency: As needed for annual reports

- Product(s): Nuclear fuel costs

- Economic Sector(s): Electric utilities.

Modeling Features:

- Model Structure: Equations described in model documentation

- Modeling Technique: Deterministic

- Special Features: Lotus 1-2-3 electronic spreadsheet. 
Non-DOE Input Sources:

- NUEXCO, Monthly Report on the Nuclear Fuel Market (Denver, CO)

- Uranium Price

- Conversion price

- Fabrication price

- Enrichment price

- Unit cost of waste disposal

- DRI, Utility Cost of Finance for Debt, Preferred Equity, and Common Equity

- Utility cost of capital

- Lag for revenue collection

- Standard and Poor's Compustat Services, Inc., The Compustat Tapes, Denver, CO, and subsequent releases

- Utility cost of capital

- Lag for revenue collection.

DOE Data Input Sources:

Forms and Publications:

- Energy Information Administration World Nuclear Fuel Cycle Requirements, DOE/EIA-0436 (Washington, DC, September 1988).

- Thermal rating of nuclear plant

- Electrical ratings

- Cycle length

- Full power days per cycle

- Fresh fuel assay

- Discharge burnup

- Batch fraction

- Process loss

- Lead time
Models and Other:

- Office of the Assistant Secretary for Nuclear Energy, Office of the Deputy Assistant Secretary for Uranium Enrichment

- Enrichment contracting terms (base enrichment price, VTAO surcharge, enrichment tails assay).

General Output Descriptions: LNFCC-PC is used to estimate and interpret the cost of commercial nuclear reactor fuel.

Computing Environment:

- Hardware Used: IBM-compatible personal computer

- Operating System: MS-DOS

- Language/Software Used: Lotus 1-2-3, Ver. 1.0

- Memory Requirement: $640 \mathrm{~Kb}$

- Storage Requirement: $27 \mathrm{~Kb}$

- Estimated Run Time: On an IBM AT, 30-40 CPU seconds

- Special Features: Interactive.

Independent Reviews Conducted: None.

Status of Evaluation Efforts by Sponsor: None.

\section{Low-Income Household Energy As- sistance Program (LIHEAP)}

Description: LIHEAP is a set of State-level regression equations used to project State residential energy prices for the current year with 3-year projections, based on national-level residential price projections produced for the Energy Information Administration's (EIA) Short-Term Energy Outlook. LIHEAP produces 51 separate sets of projections of residential prices ( 50 for each State and 1 for the District of Columbia), including prices for electricity, natural gas, heating oil, liquefied petroleum gas (LPGpropane), kerosene and coal. Less than 51 projections are available where historical information for a State is nonexistent or unavailable. The State price projections from LIHEAP are published annually in the EIA service report, State Energy Price Projections for the Residential Sector.

Last Model Update: November 1993.

Part of Another Model? No.

Model Interfaces: The model utilizes annualized forecasts from the Short-Term Integrated Forecasting System 
(STIFS) as reference inputs to the State-level forecasting equations.

\section{Sponsor:}

- Office: Office of Energy Markets and End Use

- Division: Energy Markets and Contingency Information Division

- Branch: Financial Analysis Branch, EI-622

- Model Contact: Marie Fagan

- Telephone: 586-1452.

Documentation: Energy Information Administration, State Energy Price Projections for the Residential Sector 1992, SR/EMEU/91-04 (Washington, DC, September 1992).

Archive Media and Installation Manual(s): LIHP92 Low-Income Household Energy Assistance Program, archived for the State Energy Price Projections for the Residential Sector 1993-1994 and for purposes of documentation.

Purpose: The purpose of LIHEAP is to generate the model State-level residential price estimates that are consistent with historical trends and which accurately reflect the relative per-unit cost of energy delivered to residences. The prices are used by the Administration for Children and Families, U.S. Department of Health and Human Services, to determine the allocation formula to be used in the event that Congress funds low-income energy assistance above a baseline amount.

Energy System Described by Model: State-level residential energy prices of the residential sector, including prices for electricity, natural gas, heating oil, LPG (propane), kerosene and coal.

\section{Coverage:}

- Geographic: 50 U.S. States and the District of Columbia

- Time Unit/Frequency: Run annually with 3 projections

- Product(s): Energy prices

- Economic Sector(s): Residential

Modeling Features:

- Model Structure: The model consists of approximately 300 separate regression equations for State-level residential prices, each of which includes as the principal determinant the corresponding national-level residential price. For some States, little or no information on some prices exists, and in these cases, either no estimates are made or a simple simulation rule is applied to forecast State-level prices.

- Modeling Technique: The equations are estimated by ordinary least squares (OLS), and in some instances a first-order autoregressive error process is estimated using an iterative nonlinear estimation technique. Projections are obtained from the model by separately simulating each State-level equation, given nationallevel price forecasts and information on lagged values of the model variables needed to work through the autoregressive error process. Selective final adjustments are made to the projections in a spreadsheet if resulting projections are out of line with recent historical trends or if a calculated weighted average of the State-level projections are more than 5 percent different from the national-level price from which they were derived.

- Special Features: None.

Non-DOE Input Sources:

- Not applicable.

DOE Data Input Sources:

Forms and Publications:

- Energy Information Administration State Energy Price and Expenditures Report 1991 (Washington, DC).

- State-level residential price history (1970-1991)

- National-level residential energy prices

- Energy Information Administration, State Energy Data System

- State-level Btu conversion factors

- State-level residential sector energy consumption weights

Models and Other:

- Energy Information Administration, Short-Term Integrated Forecasting System

- National-level residential energy prices.

General Output Descriptions: State-level residential sector energy prices for electricity, natural gas, heating oil, LPG (propane), kerosene, and coal.

Computing Environment:

- Hardware Used: IBM 370/3084 and IBM-compatible personal computer 
- Operating System: Joint mainframe and PC system

- Language/Software Used: SAS, Ver. 6.0; Lotus 1-2-3 Ver. 2.2

- Memory Requirement: $4 \mathrm{Mb}$ - mainframe; $250 \mathrm{~Kb}$ for personal computer memory

- Storage Requirement: 3500 Blks - mainframe; $300 \mathrm{~Kb}$ for personal computer

- Estimated Run Time: 240 CPU seconds

- Special Features: None.

Independent Reviews Conducted: None.

Status of Evaluation Efforts by Sponsor: None.

\section{Market Penetration Model for Ground Water Heat Pump Systems (MPGWHP-PC)}

Description: MPGWHP-PC for ground water heat pump systems was developed to project the potential of these systems to displace primary energy from the present up to the year 2030. The model provides projections in 5-year increments for 4 aggregated groups of the $10 \mathrm{DOE}$ regions.

Last Model Update: October 1991.

Part of Another Model? No.

Model Interfaces: None.

Sponsor:

- Office: Office of Integrated Analysis and Forecasting

- Division: Energy Supply and Conversion Division

- Branch: Coal, Uranium and Renewable Fuels Analysis Branch, EI-822

- Model Contact: Thomas Petersik

- Telephone: 202-586-6582.

Documentation: Energy Information Administration, Market Penetration Model for Ground Water Heat Pump Systems Documentation, prepared for the Energy Information Administration (Washington, DC, December 31, 1990).
Archive Media and Installation Manual(s):

- MPM91 - archived for the Annual Energy Outlook 1991

- MPM92 - archived for the Annual Energy Outlook 1992.

Purpose: MPGWHP-PC projects the potential of ground water heat pump systems to displace primary energy from the present up to the year 2030 .

Energy System Described by Model: The potential displacement of primary energy resources from installation of ground water heat pump systems in new and existing commercial and residential buildings in the United States.

\section{Coverage:}

- Geographic: Groups of DOE regions--1, 2, and 3; 5 and $7 ; 4$ and $6 ;$ and 8,9 , and 10

- Time Unit/Frequency: 1990 through 2030 in 5-year increments

- Product(s): Building heating and cooling

- Economic Sector(s): Commercial and residential buildings.

Modeling Features:

- Model Structure: Values of the various parameters are displayed in successive matrices, with a column for each year and a row for each region

- Modeling Technique: Successive tables of values calculated from previously entered or calculated tables of values

- Special Features: None.

Non-DOE Input Sources:

- R.S. Means, 1990 Mechanical Cost Data

- Various HVAC (heating, ventilation and air-conditioning) component prices (used in determining energy cost savings)

- Jim Bose, University of Oklahoma, Executive Director of the International Ground Source Heat Pump Association, and various ground loop installers

- Ground water heat pump system costs

- Water Furnace International

- Simulations used to estimate residential energy use (used in determining energy cost savings) 
- Dan Ellis, President of Water Furnace International

- Technology acceptance factors

- Revised ground water heat pump production data

- American Society of Heating, Refrigeration and Air Conditioning Engineers

- Algorithms used in Water Furnace International simulations

- Science Applications International Corporation, Air Conditioning Technology and Markets Assessment, prepared for Southern California Edison Company

- Function defining relationships between market penetration and payback period

- Interviews by Science Applications International Corporation personnel

- Technology acceptance factors.

\section{DOE Data Input Sources:}

Forms and Publications:

- Energy Information Administration, Annual Energy Outlook 1989, DOE/EIA-0383(89) (Washington, DC, January 1989)

- Energy use by end use

- Energy Information Administration, Annual Energy Review 1988, DOE/EIA-0384(88) (June 1989)

- Energy use by end use

- Energy Information Administration, Nonresidential Buildings Energy Consumption Survey: Characteristics of Commercial Buildings 1986, DOE/EIA-0246(86) (October 1988)

- Energy use by end use--commercial

- Energy Information Administration, Residential Energy Consumption Survey: Housing Characteristics 1987, DOE/EIA-0314(87) (Washington, DC, June 1989).

- Energy use by end use--residential

- Energy Conservation Multi-Year Plan, FY 1990-1994

- Energy use by end use
Models and Other:

- Federal Energy Management Program, ASEAM (A Simplified Energy Analysis Method) simulation program

- Simulations used to estimate commercial energy use (used in determining energy cost savings)

- Energy Information Administration, Annual Energy Outlook (AEO) Forecasting System base case

- Conventional electricity prices (used in determining energy cost savings)

- Lew Pratsch, Renewable Energy Office, Renewable Energy Technologies Division, Geothermal Technology Branch

- Ground water heat pump production data.

General Output Descriptions: Simple payback periods, market share for ground water heat pump systems, and energy contribution potential of ground water heat pump systems.

\section{Computing Environment:}

- Hardware Used: IBM-compatible personal computer

- Operating System: MS-DOS

- Language/Software Used: Lotus 1-2-3, Release 3.1

- Memory Requirement: 2Mb RAM

- Storage Requirement: Approximately $225 \mathrm{~Kb}$ for each case (base, conventional energy tax, accelerated renewables)

- Estimated Run Time: Essentially instantaneous (spreadsheet automatically recalculates when changes in values of input data are entered)

- Special Features: None.

Independent Reviews Conducted: None.

Status of Evaluation Efforts by Sponsor: None.

\section{Market Penetration Model for Residential Rooftop Photovoltaic Systems (MPRESPV-PC)}

Description: MPRESPV-PC for residential rooftop photovoltaic systems was developed to project the potential of these systems to displace primary energy from the 
present up to the year 2030 . The model provides projections in 5-year increments for 4 aggregated groups of the 10 DOE regions.

Last Model Update: October 1991.

Part of Another Model? No.

Model Interfaces: None.

\section{Sponsor:}

- Office: Office of Integrated Analysis and Forecasting

- Division: Energy Supply and Conversion Division

- Branch: Coal, Uranium and Renewable Fuels Analysis Branch, EI-822

- Model Contact: Thomas Petersik

- Telephone: 202-586-6582.

Documentation: Energy Information Administration, Market Penetration Model for Residential Rooftop Photovoltaic Systems (Washington, DC, December 31, 1990).

Archive Media and Installation Manual(s):

- MPM91 - archived for the Annual Energy Outlook 1991

- MPM92 - archived for the Annual Energy Outlook 1992.

Purpose: MPRESPV-PC projects the potential of residential rooftop photovoltaic systems to displace primary energy from the present up to the year 2030.

Energy System Described by Model: The potential displacement of primary energy resources from installation to photovoltaic systems on rooftops of new and existing residences in the United States.

\section{Coverage:}

- Geographic: Groups of DOE regions--1 and 2; 3 and $5 ; 4,7$, and $10 ;$ and 6,8 , and 9

- Time Unit/Frequency: 1990 through 2030 in 5-year increments

- Product(s): Electricity

- Economic Sector(s): Residential buildings.

\section{Modeling Features:}

- Model Structure: Values of the various parameters displayed in successive matrices, with a column for each year and a row for each region

- Modeling Technique: Successive tables of values calculated from previously entered or calculated tables of values

- Special Features: None.

Non-DOE Input Sources:

- DRI/McGraw-Hill, Inc., Energy Review, Winter 1989 - 1990.

- Residential electricity demand--through 2010

- Science Applications International Corporation, Renewable Energy Technology Characterizations, prepared for DOE's National Energy Strategy.

- Photovoltaic electricity costs

- Science Applications International Corporation, Air Conditioning Technology and Markets Assessment, prepared for Southern California Edison Company.

- Function defining relationships between market penetration and payback period

- Interviews by Science Applications International Corporation personnel

- Technology acceptance factors

- Gary Jones, Sandia National Laboratory

- Data used to estimate photovoltaic electricity costs.

\section{DOE Data Input Sources:}

Forms and Publications:

- Energy Information Administration, Solar Collector Manufacturing Activity Report, DOE/EIA-0714 (Washington, DC).

- Residential photovoltaic system shipments

Models and Other:

- Energy Information Administration AEO Forecasting System base case

- Conventional electricity costs 
- Energy Information Administration, Office of Coal, Nuclear, Electric and Alternate Fuels

- Residential electricity demand--beyond 2010

- Conversion efficiency.

General Output Descriptions: Simple payback period, photovoltaic system market share, new and retrofit primary electrical energy market, and cumulative energy contribution potential of residential photovoltaic systems by annual production method, market penetration model, and combined method.

Computing Environment:

- Hardware Used: IBM-compatible personal computer

- Operating System: MS-DOS

- Language/Software Used: Lotus 1-2-3, Release 3.1

- Memory Requirement: 2Mb RAM

- Storage Requirement: Approximately $65 \mathrm{~Kb}$ for each case (base, conventional energy tax, accelerated renewables)

- Estimated Run Time: Essentially instantaneous (spreadsheet automatically recalculates when changes in values of input data are entered)

- Special Features: None.

Independent Reviews Conducted: None.

Status of Evaluation Efforts by Sponsor: None.

\section{Market Penetration Model for AC- tive and Passive Solar Tech- nologies (MPSOLAR-PC)}

Description: MPSOLAR-PC for active and passive solar technologies was developed to project the potential of these systems to displace primary energy from the present up to the year 2030. The model provides projections in 5-year increments for nine solar technologies: Residential and Commercial Active Solar Water Heating; Residential and Commercial Active Solar Combined Space and Water Heating Systems; Residential and Commercial Passive Solar Space Heating; Residential and Commercial Active Solar Space Cooling Systems; and Commercial Daylighting.

Last Model Update: October 1991.

Part of Another Model? None.
Model Interfaces: A spreadsheet named SUMMARY is set up to import the results of MPSOLAR for each of the 4 Census regions, and then to disaggregate these results into results for each of the $10 \mathrm{DOE}$ regions.

Sponsor:

- Office: Office of Integrated Analysis and Forecasting

- Division: Energy Supply and Conversion Division

- Branch: Coal, Uranium and Renewable Fuels Analysis Branch, EI-822

- Model Contact: Thomas Petersik

- Telephone: 202-586-6582.

Documentation: Energy Information Administration, Market Penetration Model for Active and Passive Solar Technologies Documentation (Washington, DC, December 31, 1990).

Archive Media and Installation Manual(s):

- MPM91 - archived for the Annual Energy Outlook 1991

- MPM92 - archived for the Annual Energy Outlook 1992.

Purpose: MPSOLAR-PC projects the potential of active and passive solar technologies to displace primary energy from the present up to the year 2030.

Energy System Described by Model: The potential displacement of primary energy resources from installation of active and passive solar systems on new and existing commercial and residential buildings in the United States.

\section{Coverage:}

- Geographic: Groups of DOE regions--1, 2, and 3; 5 and $7 ; 4$ and $6 ;$ and 8,9 , and 10

- Time Unit/Frequency: 1989 and 1990 through 2030 in 5 -year increments

- Product(s): Active water heating, active space and water heating, passive heating, active cooling, and daylighting

- Economic Sector(s): Commercial and residential buildings.

\section{Modeling Features:}

- Model Structure: Values of the various parameters are displayed in successive matrices, with a column for each year and a row for each region. 
- Modeling Technique: Successive tables of values calculated from previously entered or calculated tables of values.

- Special Features: None.

\section{Non-DOE Input Sources:}

- Science Applications International Corporation, Renewable Energy Technology Characterizations, prepared for DOE's National Energy Strategy

- Revised solar system costs

- Science Applications International Corporation, Air Conditioning Technology and Markets Assessment, prepared for Southern California Edison Company

- Function defining relationships between market penetration and payback period

- Technology acceptance diffusion factors

- Interviews by Science Applications International Corporation personnel

- Technology acceptance diffusion factors

- F-Chart (F-Chart Software, Middleton, WI) and TRNSYS simulations performed for the Solar Buildings Technology Performance Office

- Solar system performance--active solar water heating, active solar combined space and water heating, passive solar space heating, commercial daylighting

- Analyses performed by Solar Energy Research Institute (SERI), Golden, CO

- Solar system performance--active solar space cooling.

\section{DOE Data Input Sources:}

Forms and Publications:

- Energy Information Administration, Annual Energy Outlook 1989, DOE/EIA-0383(89) (Washington, DC, January 1989).

- Energy use by end use

- Energy Information Administration, Nonresidential Buildings Energy Consumption Survey: Characteristics of Commercial Buildings 1986, DOE/EIA-0246 (Washington, DC, October 1988)

- Energy use by end use--commercial
- Energy Information Administration, Residential Energy Consumption Survey: Housing Characteristics 1987, DOE/EIA-0314 (Washington, DC, June 1989).

- $\quad$ Energy use by end use--residential

- Energy Information Administration, Annual Energy Review 1988, DOE/EIA-0384(88) (Washington, DC, June 1989).

- Energy use by end use

- Energy Conservation Multi-Year Plan FY 1990 - 1994

- Energy use by end use

- Solar Buildings Technology Program Office, National Solar Buildings Technology Program, Multi-Year Program Plan FY 1990 - 1994.

- Solar system costs

- Energy Information Administration, Solar Collector Manufacturing Activity Report, DOE/EIA-0174 (Washington, DC, December 1989).

- Active solar collector production and the area of solar collectors sent to each State in the United States, 1973 - 1987 (used in estimating energy use by end use)

Models and Other: Energy Information Administration, AEO Forecasting System base case

- Conventional energy prices.

General Output Descriptions: Simple payback periods, solar systems market share, annual energy contribution of solar systems.

Computing Environment:

- Hardware Used: IBM-compatible personal computer

- Operating System: MS-DOS

- Language/Software Used: Lotus 1-2-3, Release 3.1

- Memory Requirement: 2Mb RAM

- Storage Requirement: Approximately $115 \mathrm{~Kb}$ for each case (base, conventional energy tax, accelerated renewables) and region

- Estimated Run Time: Essentially instantaneous (spreadsheet automatically recalculates when changes in values of input data are entered)

- Special Features: None. 
Independent Reviews Conducted: None.

Status of Evaluation Efforts by Sponsor: None.

\section{Motor Gasoline Market Model (MGMM)}

Description: The MGMM performs a short-term (6 to 9 month) forecast of demand and price in the U.S. motor gasoline market. The model also calculates the end of month stock level. The model is used to analyze certain market behavior assumptions or market shocks and to determine their effect on market price, demand and stocks.

Last Model Update: April 1993.

Part of Another Model? No.

\section{Model Interfaces:}

- None. The MGMM uses inputs from STIFS, from which it obtains economic and refinery data.

Sponsor:

- Office: Office of Oil and Gas

- Division: Petroleum Marketing Division

- Branch: Publications and Analysis, EI-432

- Model Contact: John Zyren

- Telephone: 202-586-6405.

Documentation: Energy Information Administration, Motor Gasoline Market Model Documentation Report, DOE/EIA-M054 (Washington, DC, September 1993).

Archive Media and Installation Manual(s): Archived on floppy disks, with internal documentation. Available from sponsoring office.

Purpose: The MGMM was developed to provide support for the Motor Gasoline Outlook article published in the Petroleum Marketing Monthly. The MGMM assesses the market response to alternative market scenarios and/or shocks. The model relies on the STIFS mid-world oil price case for values of economic and refinery behavior variables to define a base-line and then uses assumptions on different possible market disturbances to assess their effects on a monthly basis. The MGMM provides a framework to calculate stock levels from the estimated demand and price variables.

Energy System Described by Model: Motor gasoline demand and prices.
Coverage:

- Geographic: National

- Time Unit/Frequency: Monthly

- Product(s): Motor Gasoline

- Economic Sector(s): Retail motor gasoline market.

Modeling Features:

- Model Structure: Recursive multi-equation model

- Modeling Technique: Ordinary least squares, with correction for autocorrelation

- Special Features: None.

Non-DOE Input Sources:

- Data Resources Inc. (DRI) data base, data from Bureau of Economic Analysis and Bureau of Labor Statistics

- Macroeconomic production price and income variables

- Retail price of motor gasoline

- Federal Highway Administration, Traffic Volume Trends, various issues

- Vehicle miles traveled.

DOE Data Input Sources:

Forms and Publications:

- Energy Information Administration, Petroleum Supply Annual, DOE/EIA-0340 and Petroleum Supply Monthly, DOE/EIA-0109.

- Finished motor gasoline and blending component stocks

- Energy Information Administration, Petroleum Marketing Annual, DOE/EIA-0487 and Petroleum Marketing Monthly, DOE/EIA-0380.

- Average crude oil refiner's acquisition costs

Models and Other:

- Energy Information Administration, Short-Term Integrated Forecasting System

- Forecasts of economic and refinery variables. 
General Output Descriptions: MGMM is used to generate very short-term (up to 9 months), monthly forecasts of U.S. demand, price and stock levels of retail motor gasoline.

Computing Environment:

- Hardware Used: IBM-compatible personal computer

- Operating System: MS-DOS

- Language/Software Used: Micro-TSP, Ver. 7.01 or higher

- Memory Requirement: $640 \mathrm{~Kb}$

- Storage Requirement: $640 \mathrm{~Kb}$

- Estimated Run Time: 30 seconds calculation time on an 80386 personal computer operating under DOS 5

- Special Features: None.

Independent Reviews Conducted: None.

Status of Evaluation Efforts by Sponsor: Ongoing.

\section{Oil Market Simulation Model (OMS- PC)}

Description: OMS-PC projects future world oil prices and world oil supplies and demands by region (the United States, Canada, Japan, and the Organization for Economic Cooperation and Development (OECD)-Europe, the Organization of Petroleum Exporting Countries (OPEC), developing countries, and net Communist trade) on an annual basis through the year 2010. The OMS-PC model is used as an adjunct to the World Energy Projection System (WEPS-PC).

Last Model Update: July 1994.

Part of Another Model? No.

Model Interfaces: Inputs from STIFS.

Sponsor:

- Office: Office of Integrated Analysis and Forecasting

- Division: Energy Demand and Integration Division

- Branch: International, Economic and Integrated Forecasting Branch, EI-812

- Model Contact: Dan Butler
Documentation:

- Energy Information Administration, Oil Market Simulation Model Documentation Report, DOE/EIAM028 (Washington, DC, May 1985).

Archive Media and Installation Manual(s):

- OMS85 -International Energy Outlook 1985

- OMS86-International Energy Outlook 1986

- OMS87 -International Energy Outlook 1987

- OMS89 -Intemational Energy Outlook 1989

- OMS90 -International Energy Outlook 1990 and the Annual Energy Outlook 1990

- OMS91 -International Energy Outlook 1991 and the Annual Energy Outlook 1991

- OMS92 -International Energy Outlook 1992 and the Annual Energy Outlook 1992

- OMS93 -International Energy Outlook 1993 and the Annual Energy Outlook 1993

- OMS94 -Intemational Energy Outlook 1994 and the Annual Energy Outlook 1994.

Purpose: OMS-PC forecasts annual world oil prices and regional supplies and demands through the year 2010. The model consists of regional oil supply and demand equations with oil supply a composite of conventional sources and oil demand determined as a function of both prices and income. The model can be used to simulate OPEC production, given a projection of world crude oil prices, or to estimate oil prices for any given level of OPEC production capacity.

Energy System Described by Model: The model describes world oil supply and demand on a regional basis annually from the present through the year 2010.

Coverage:

- Geographic: U.S., Canada, Japan, OECD-Europe, OPEC, and developing countries

- Time Unit/Frequency: From the present through the year 2010 , annually

- Product(s): Crude oil and natural gas liquids

- Economic Sector(s): All oil consuming countries, regionalized as above.

- Telephone: 202-586-9503. 
Modeling Features:

- Model Structure: Dynamic, recursive

- Modeling Technique: Parametric representation of embodied aggregate supply and demand elasticities

- Special Features: Operational, both in interactive and batch mode.

\section{Non-DOE Input Sources:}

- Cambridge Energy Research Associates, The Capacity Race--The Future of World Oil Supply

- Reference price--international

- Central Intelligence Office of Economic Research, International Energy Statistical Review

- OPEC production capacity--through 1980.

DOE Data Input Sources:

Forms and Publications:

- Energy Information Administration, Annual Energy Outlook, DOE/EIA-0383 (Washington, DC).

- U.S. supply/demand projections

- Energy Information Administration, Short-Term Energy Outlook, DOE/EIA-0202 (Washington, DC).

- U.S. supply/demand projections

- Energy Information Administration, International Petroleum Statistics, DOE/EIA-0520 (Washington, DC).

- Historical consumption - international

- Historical production - international

- Data used to estimate price elasticities, income elasticities, feedback elasticities and lags

- Energy Information Administration, Intemational Energy Annual, DOE/EIA-0219 (Washington, DC).

- Historical consumption - international

- Historical production - international

- Data used to estimate price elasticities, income elasticities, feedback elasticities and lags

- Energy Information Administration, Monthly Energy Review, DOE/EIA-0035 (Washington, DC).
- World oil prices

- U.S. historical supply/demand

- Energy Information Administration, Annual Energy Review, DOE/EIA-0384.

- World oil price

- U.S. historical supply/demand

- Office of International Affairs, International Energy Indicators, DOE/IA/0010/6, December 1980 (Washington, DC).

- OPEC production capacity--through 1980

Models and Other:

- Internal estimates from International, Economic and Integrated Forecasting Branch, EI-812

- OPEC production capacity--1981 forward.

General Output Descriptions: OMS-PC model users can specify the world oil price path over time. The model accepts the user-specified prices to compute the world regional demand and supply. Output of this includes OPEC production, free world production, free world consumption, net U.S. imports, OPEC revenues, and excess OPEC capacity. The OPEC price reaction function can be used to evaluate oil prices. OMS-PC model users specify the demand and supply path over time. The model accepts these to compute world price levels. Output is similar to that of a production run, except that price is included as well. An OMS-PC model user can also specify an OPEC output (production) path, and the model will search for a world oil price such that the model solution will converge to the user-specified quantity or levels. Output of this run is similar to that of a price run. In a disruption run, OMSPC model users can specify a reduction in OPEC capacity to trigger the disruption algorithm, and the model will be solved for world oil price, world oil demand, and world oil supply.

\section{Computing Environment:}

- Hardware Used: IBM-compatible personal computer

\section{- Operating System: MS-DOS}

- Language/Software Used: Lotus 1-2-3, Release 2

- Memory Requirement: 1.2Mb to load Lotus 1-2-3 and retrieve the OMS model (the largest file on the OMS diskette), $200 \mathrm{~Kb}$ to use the DEMO diskette

- Storage Requirement: $300 \mathrm{~Kb}$ 
- Estimated Run Time: On a Compaq 386, 10 seconds

- Special Features: Fast turnaround.

Independent Reviews Conducted:

- Oil Market Simulation Model Documentation Review Report, John Kraft, Independent Expert Review, October 13, 1980

- Oil Market Simulation Model Documentation Report, William Gaynor, Independent Expert Review, February 15, 1983

- Oil Market Simulation Model Documentation Report, William M. Fitzgerald, Independent Expert Review, November 25, 1983

- An Evaluation of the Oil Market Simulation Model, Dennis Epple, Independent Expert Review, April 1986

- International Oil Supply and Demand, Energy Modeling Forum, Stanford University, Palo Alto, CA, September 1991.

Status of Evaluation Efforts by Sponsor: None.

\section{Petroleum Financial Analysis Sys- tem (PETFAS-PC)}

Description: PETFAS-PC is designed to utilize Annual Energy Outlook (AEO) model results for oil and gas prices, domestic drilling levels and drilling cost relationships. It also uses information from the $A E O$ on oil and gas reserves and production to provide forecasts of investment and profits for the U.S. oil and gas production industry. Detailed income statement, capital account, balance sheet, and tax information is provided for two main industry categories--major energy companies' domestic oil and gas segments and domestic independent producers.

Last Model Update: February 1990.

Part of Another Model? Designed not as a principal model involved in iterative solution algorithm for $P C-A E O$, but as a post-solution report writer with some embedded behavioral characteristics relating to industry structure. Can operate in stand-alone mode with internal oil and gas supply equations or with Annual Energy Outlook inputs supplemented by user options.

Model Interfaces: In Annual Energy Outlook mode, uses inputs directly from the oil and gas and macro modules solutions from $P C-A E O$ to forecast investment and income for the oil and gas sector.
Sponsor:

- Office: Office of Energy Markets and End Use

- Division: Energy Markets and Contingency Information Division

- Branch: Financial Analysis Branch, EI-622

- Model Contact: Marie Fagan

- Telephone: 202-586-1452.

Documentation: Energy Information Administration, $U p$ dated Model Documentation for the Petroleum Financial Analysis Personal Computer Model (PETFAS), February 1993.

Archive Media and Installation Manual(s): None.

Purpose: PETFAS-PC is used to make explicit the implications for financial health/performance of the domestic oil and gas industry embedded in $P C-A E O$ and other energy model results.

Energy System Described by Model: Domestic oil and gas production industry.

\section{Coverage:}

- Geographic: National

- Time Unit/Frequency: Annual

- Product(s): None

- Economic Sector(s): U.S. oil and gas production sector, for total United States, majors and independents.

Modeling Features:

- Model Structure: Recursive model. Calculates aggregate financial results for aggregate industry using inputs on real activity levels and prices from $P C-A E O$ or elsewhere as exogenous. Solves in top-down fashion for industry sector results.

- Modeling Technique: Key behavioral relationships estimated using ordinary least squares regressions on pooled time-series cross-section data base created from survey data at the corporate level.

- Special Features: Constructed in Lotus 1-2-3 with menu-driven structure to allow user to specify alternative input assumptions.

Non-DOE Input Sources: None. 
Forms and Publications: None

Models and Other: Energy Information Administration, Personal Computer - Annual Energy Outlook (PC-AEO) Model

- Drilling/equipping expenditure

- Unit drilling and equipping cost

- Footage drilled

- Domestic reserves added

- Shares of total reserves added

- Domestic production

- Domestic reserves

- Real-world oil price

- Real domestic wellhead gas price

- Corporate bond yield

- Wholesale price index

General Output Descriptions: Detailed output for both industry sectors on revenue and expenses (including windfall profits tax), operating income, interest expense, pretax income, sources of tax deferral, income tax calculations, investment in fixed assets, changes in long-term debt and stockholders' equity. Results make possible comparisons over time and between sectors of cash flow, changes in financial condition, and effective tax rates.

Computing Environment:

- Hardware Used: IBM-compatible personal computer

- Operating System: MS-DOS, Ver. 3.2 or higher

- Language/Software Used: Lotus 1-2-3, Ver. 2.01 or higher

- Memory Requirement: $1 \mathrm{Mb}$

- Storage Requirement: $330 \mathrm{~Kb}$ of disk space

- Estimated Run Time: On a Compaq 386/16 operating under DOS 3.31 approximately 5 minutes

- Special Features: None.

Independent Reviews Conducted: None.

Status of Evaluation Efforts by Sponsor: None.
Description: The PPMM performs a short-term (6 to 9 month) forecast of demand and price in the residential U.S. propane market; the model also calculates the end-ofmonth stock level. The model can also be used to calculate the demand and end-of-month stock level in several PAD districts. The model is used to analyze certain market behavior assumptions or market shocks and to determine their effect on market price, demand, and stocks.

Last Model Update: October 1993.

Part of Another Model? No.

Model Interfaces: The PPMM uses inputs from STIFS, from which it obtains economic and refinery data.

Sponsor:

- Office: Office of Oil and Gas

- Division: Petroleum Marketing Division

- Branch: Publications and Analysis, EI-432

- Model Contact: John Zyren

- Telephone: 202-586-6405

Documentation: Energy Information Administration, Model Documentation of the Propane Market Model, DOE/EIA-M055 (Washington, DC, October 1993).

Archive Media and Installation Manual(s): Archived on micro-floppy disks.

Purpose: PPMM was developed to provide support for the Propane Outlook article published in the Petroleum Marketing Monthly. The PPMM assesses the market response to alternative market scenarios and/or shocks. The model uses the STIFS mid-world oil price case for values of economic and refinery behavior variables to assist in defining a base-line case and then uses assumptions on different possible market disturbances to assess their effects on a monthly basis. The PPMM provides a framework to calculate stock levels from the estimated demand and price variables.

Energy System Described by Model: The residential propane demand, end-user prices, and end-of-month stock levels.

Coverage:

- Geographic: National, PAD Districts 1 and 2

- Time Unit/Frequency: Monthly

- Product(s): Consumer-grade propane 
- Economic Sector(s): Residential propane market

Modeling Features:

- Model Structure: Multi-equation model

- Modeling Technique: Ordinary least squares, with correction for autocorrelation

- Special Features: None.

Non-DOE Input Sources:

- Data Resources, Inc. (DRI) database, data from the Bureau of Labor Statistics

- Producer price index data

- U.S. Department of Commerce, National Oceanographic and Atmospheric Administration, Data Source DRD 964X

- Actual and normal statewide monthly heating degree day values.

DOE Data Input Sources:

Forms and Publications:

- Energy Information Administration, Petroleum Supply Annual, DOE/EIA-0340 and Petroleum Supply Monthly, DOE/EIA-0109 (Washington, DC).

- Propane/propylene stocks and product supplied

- Energy Information Administration, Petroleum Marketing Annual, DOE/EIA-0487 and Petroleum Marketing Monthly, DOE/EIA-0380 (Washington, DC).

- Average imported crude oil refiner acquisition costs, refiner price of propane (consumer-grade) sales to end users

- Energy Information Administration, Winter Fuels Report, DOE/EIA-0538, various issues

- Residential propane prices

Models and Other:

- Energy Information Administration, Short-Term Integrated Forecasting System

- Forecasts of economic and refinery variables.

General Output Descriptions: PPMM is used to generate very short-term (up to 9 months), monthly forecasts of U.S. demand, price, and stock levels of residential (consumer- grade) propane. There is also provision for demand forecasts in certain PAD districts.

Computing Environment:

- Hardware Used: IBM-compatible personal computer

- Operating System: MS-DOS

- Language/Software Used: Micro-TSP, Ver. 7.01 or higher

- Memory Requirement: $640 \mathrm{~Kb}$

- Storage Requirement: $640 \mathrm{~Kb}$

- Estimated Run Time: 30 seconds calculation time on an 80386 personal computer operating under DOS 5

- Special Features: None.

Independent Reviews Conducted: None.

Status of Evaluation Efforts by Sponsor: Ongoing.

\section{Refinery Yield Model Spreadsheet System (RYMSS-PC)}

Description: RYMSS-PC simulates the operations of a refinery or group of refineries within the United States, including the processing of crude oils and other raw materials, as well as the processing of these raw materials into finished petroleum products. Refinery product yields and net margins are generated which can be used in comparative and sensitivity analyses, using RYMSS-PC.

Last Model Update: June 1993.

Part of Another Model? No.

Model Interfaces: No direct interface.

Sponsor:

- Office: Office of Oil and Gas

- Division: Petroleum Marketing Division

- Branch: Publications and Analysis, EI-432

- Model Contact: Charles Dale

- Telephone: $202-586-1805$.

Documentation: Energy Information Administration, Refinery Yield Model Spreadsheet System, RYMSS-PC, Documentation, DOE/EIA-M037 (Washington, DC, April 1989). 
Archive Media and Installation Manual(s): RYMSS.WK1 - archived on floppy disk.

Purpose: RYMSS-PC simulates refinery operations in order to perform comparative and sensitivity analyses on refinery product yields and refinery net margins.

Energy System Described by Model: U.S. refinery processes and product production.

\section{Coverage:}

- Geographic: United States: 50 States and territories, but can be used for any region for which adequate data are available.

- Time Unit/Frequency: The data base contains 1987 annual data. However, because the units used within the model are in terms of rates, the static version of the model can be used over any single period of time. The data base, of course, would have to be revised.

- Product(s): The RYMSS-PC represents the processing of 28 reference crude oils plus unfinished oils and other hydrocarbon inputs in the refinery(s), and the production of more than 20 refinery products using 17 separate, detailed refinery processes.

- Economic Sector(s): None.

\section{Modeling Features:}

- Model Structure: RYMSS-PC is a static simulation model which determines product yields and net refinery margins given input data on crude oils and other raw material inputs (type, and volume), product prices (and volume for a few select products), finished motor gas specifications (octane and Reid vapor pressure), and refinery configuration.

- Modeling Technique: Static simulation.

- Special Features: An important feature of RYMSS$\mathrm{PC}$ is that the major petroleum products (motor gasoline, jet fuels, distillate, and residual) can be blended to specification. (When product specifications are not met, the message 'non spec' will be given.) This feature allows an excellent representation of the refinery adjustments necessary to produce products to specifications. Input tables within RYMSS-PC define specifications such as Reid vapor pressure, viscosity, flash point, octane rating, API gravity, and sulfur content. Another special feature is provided through the RYMSS-PC to automatically converge upon the reformer severity necessary to produce motor gasoline at a predetermined pool octane rating across a range of Reid vapor pressure settings.
Non-DOE Input Sources:

- Platt's Oilgram Price Report, McGraw-Hill, New York

- Crude oil inputs: unit purchase cost, API gravity and weight percent sulfur

- Unfinished oils and other hydrocarbon inputs: unit purchase cost

- Product control variables: price (petrochemical feeds and unfinished naphtha)

- Petroleum Intelligence Weekly, New York

- Crude oil inputs: unit purchase cost, API gravity and weight percent sulfur

- Oil Buyers' Guide: The Authoritative Newsletter on Market Prices, Lakewood, NJ.

- Crude oil inputs: unit purchase cost, API gravity and weight percent sulfur

- Unfinished oils and other hydrocarbon inputs: unit purchase cost

- Product control variables: price (butane)

- Alcohol Outlook, Information Resources Inc., Washington, DC.

- Unfinished oils and other hydrocarbon inputs: unit purchase cost

- Product control variables: price (petrochemical feeds (aromatics: benzene, toluene, xylene))

- Oil and Gas Journal, Annual Refinery Report, March, annually

- Process unit capacity and utilization control variables: operable capacity

- Oil and Gas Joumal, November 7, 1988, and November 4,1985 , issues

- $\quad 1987$ and 1982 Nelson-Farrar cost indices

- U.S. Bureau of Mines

- Product control variables: price (sulfur)

- J.H. Gary and G.E. Handwerk, Petroleum Refining Technology and Economics, 2nd ed. (New York: Marcel Dekker, Inc., 1984), p. 174.

- Alkylation yields 
- A.M. Brownstein, Petrochemical Technology (Tulsa, OK: The Petroleum Publishing Co., 1976), p. 25.

- Aromatics recovery yields

- The Chemical Marketing Reporter

- Product control variables: price (propylene, asphalt, lubes and waxes).

\section{DOE Data Input Sources:}

\section{Forms and Publications:}

- Energy Information Administration, Form EIA-782A, "Refiners'/Gas Plant Operators' Monthly Petroleum Product Sales Report"

- Motor gasoline specifications control variables: percent of total motor gasoline yield

- Energy Information Administration, Form EIA-782B, "Reseller/Retailer's Monthly Petroleum Product Sales Report"

- Motor gasoline specifications control variables: percent of total motor gasoline yield

- Energy Information Administration, Form EIA-810, "Monthly Refinery Report"

- Crude oil inputs: volume

- Unfinished oils and other hydrocarbon inputs: volume

- Process unit capacity and utilization control variables (operable capacity and utilization rate)

- Product control variables: volume

- Energy Information Administration, Form EIA-820, "Annual Refinery Report"

- Process unit capacity and utilization control variables (operable capacity and utilization rate)

- Energy Information Administration, Form EIA-856, "Monthly Foreign Crude Oil Acquisition Report"

- Crude oil inputs: unit purchase cost, API gravity and weight percent sulfur

- Energy Information Administration, Petroleum Supply Annual, DOE/EIA-0340 (Washington, DC).

- Process unit capacity and utilization control variables (operable capacity and utilization rate)
- Energy Information Administration, Petroleum Supply Monthly, DOE/EIA-0109 (Washington, DC).

- Unfinished oils and other hydrocarbon inputs: volume

- Total motor gasoline yields used to calculate motor gasoline specifications control variables (percent of total motor gasoline yield)

- Fresh feed inputs used to derive process unit capacity and utilization control variables: utilization rate (catalytic cracking, hydrocracking and coking units)

- Energy Information Administration, Petroleum Marketing Monthly, DOE/EIA-0380 (Washington, DC).

- Crude oil inputs: unit purchase cost, API gravity and weight percent sulfur

- Sales volumes used to calculate motor gasoline specifications control variables (percent of total motor gasoline yield)

- Energy Information Administration, Petroleum Marketing Annual, DOE/EIA-0487 (Washington, DC) (Tables 2, 4, 5, and 11).

- Product control variables: price (motor gasoline, aviation gasoline, propane, kerosene, No. 2 distillate, residual fuel oil)

- Energy Information Administration, Monthly Energy Review, DOE/EIA-0035 (Washington, DC).

- Product control variables: price (still (natural) gas, power)

- Energy Information Administration, Cost and Quality of Fuel for Electric Utility Plants 1987, DOE/EIA-0191 (Washington, DC).

- Product control variables: price (petroleum coke)

\section{Models and Other:}

- Energy Information Administration, Refinery Yield Model (RYM)

- Crude oil distillation (yield and sulfur content)

- Coking unit yields

- Visbreaker yields

- Fluid catalytic cracker yields 
- Hydrocracking yields

- Catalytic reforming yields

- Isomerization yields

- Alkylation yields

- Aromatics recovery yields

- Hydrotreater yields

- Operating costs

- Gasoline blending

- Jet fuel blending

- Distillate and residual fuel oil blending.

General Output Descriptions: RYMSS-PC produces three output reports through the use of macro functions. RYMSS-PC reports include:

- The 'Input Summary' - raw material costs and volumes, products costs and volumes, and process unit configurations

- The 'Comparison' tables - comparison of the base case and an alternative (current) case 'input summary'

- The 'Refinery Output, Net Margin, and Process Summary' - product yields, prices, and revenue summary, refinery net margin accounting summary, and process unit input and out summaries.

Computing Environment:

- Hardware Used: IBM-compatible personal computer

- Operating System: MS-DOS

- Language/Software Used: Lotus $1-2-3$, Ver. 2.0 or higher

- Memory Requirement: Approximately $250 \mathrm{~Kb}$

- Storage Requirement: $250 \mathrm{~Kb}$

- Estimated Run Time: 5 seconds recalculation time on an 80386 personal computer operating under DOS 5.0, macro function/0 (optional) can take up to 2 minutes.

- Special Features: None.

Independent Reviews Conducted:

- Model Quality Audit conducted by the Office of Statistical Standards, June 1988
- Independent Expert Review conducted by George Lady, June 1988.

Status of Evaluation Efforts by Sponsor: Final Validation Report for Refinery Yield Model Spreadsheet System, Decision Analysis Corporation, Vienna, VA, January 18, 1991.

\section{Resource Allocation and Mine Costing Model (RAMC)}

Description: RAMC produces the quantity-price relationships in coal supply for 30 coal types (further distinguished between surface and deep mines) and 32 producing regions based on the 1991 EIA Demonstrated Reserve Base, engineering estimates of mining costs for various surface and underground mines, and region-specific and coal-typespecific cost elements.

Last Model Update: December 1991.

Part of Another Model? No.

Model Interfaces: No.

Sponsor:

- Office: Office of Integrated Analysis and Forecasting

- Division: Energy Supply and Conversion Division

- Branch: Coal, Uranium and Renewable Fuels Analysis Branch, EI-822

- Model Contact: Mike Mellish

- Telephone: 202-585-2136.

Documentation:

- Energy Information Administration, Documentation of the Resource Allocation and Mine Costing (RAMC) Model, DOE/EIA-M021 (Washington, DC, January 1992).

- Energy Information Administration, RAMC Surface Mining Cost Equations Development, DOE/EIA-0433 (Washington, DC, September 1983).

- Energy Information Administration, RAMC Underground Mining Cost Equations Development, DOE/EIA-0432 (Washington, DC, September 1983).

- Energy Information Administration, Documentation of the Reserve Related Data Inputs to the Resource Allocation and Mine Costing Model, DOE/NBB-0026 (Washington, DC, September 1982). 
- Energy Information Administration, Documentation of the Resource Allocation and Mine Costing (RAMC) Model, DOE/EIA-MO21 (Washington, DC, May 1987).

Archive Media and Installation Manual(s):

- RAMC79 - for the Annual Report to Congress (ARC) 1979

- RAMC80 - for the Annual Report to Congress (ARC) 1980

- RAMC81 - for the Annual Report to Congress (ARC) 1981

- RAMC82 - for the Annual Energy Outlook (AEO) 1982

- RAMC82A - for the Clean Air Act Study

- RAMC982 - for the 1982 documentation

- RAMC83 - for the Annual Energy Outlook (AEO) 1983

- RAMC84 - for the Annual Energy Outlook (AEO) 1984

- RAMC85 - for the Annual Energy Outlook (AEO) 1985

- RAMC86 - for the Annual Energy Outlook (AEO) 1986

- RAMC91 - for the Annual Energy Outlook (AEO) 1991

- RAMC92 - for the Annual Energy Outlook (AEO) 1992.

Purpose: The RAMC is used to develop coal supply curves for EIA's coal supply models. It can be used to analyze the impact of changes in coal supply or costs resulting from changes in taxes, production and preparation costs, productivity, coal reserves and other supply-related costs.

Energy System Described by Model: Potential coal supply at various minemouth prices.

\section{Coverage:}

- Geographic: Supply curves for 32 coal-producing regions

- Time Unit/Frequency: 1990 through 2010 curves

- Product(s): 30 coal types

- Economic Sector(s): Coal Supply.

Modeling Features:

- Model Structure: The RAMC employs a structural approach using engineering and economic algorithms.
- Modeling Technique: Two steps: (1) calculates reserves and (2) determines minimum acceptable selling price.

- Special Features: None.

\section{Non-DOE Input Sources:}

- BCOA Hikes Benefits Contributions: Fund Shortfalls Force \$1/Hour Increase, article in Coal Week (McGraw-Hill, September 3, 1990)

- Data on current employer contribution levels to each of the pension and trust fund plans of the United Mine Workers of America, used to derive welfare fund estimates

- Keystone Coal Industry Manual (McGraw-Hill, 1981, 1982, and 1985).

- Data used to adjust committed reserves estimates

- Information used to supplement seam depth estimates

- "Coal Industry Taxes," compiled by Donna Summons for McGraw-Hill's Mine Regulation and Productivity Report (1981).

- State and/or local taxes

- Science Applications International Corporation (SAIC), "Development of RAMC Longwall Model Mines," unpublished Final Report prepared for U.S. Department of Energy, Energy Information Administration (March 1991)

- Revised mine size distribution parameters (for the four largest underground size categories)

- Science Applications International Corporation (SAIC) "Enhancement of Short-Term Coal Supply Modeling Capabilities," unpublished Final Report prepared for U.S. Department of Energy, Energy Information Administration (March 1989)

- Capacity utilization data, used to estimate current coal-mine production capacity

- Science Applications International Corporation (SAIC), Development of Revised Reserve Inputs to the Resource Allocation and Mine Costing Model (May 1986)

- Data used to adjust committed reserves estimates

- Data used to adjust clean coal yield estimates (certain regions 
- Science Applications International Corporation (SAIC), "Revisions to the Overburden Ratio and Current Price Inputs to the RAMC," unpublished Final Report prepared for U.S. Department of Energy, Energy Information Administration (May 1986)

- Overburden ratio distribution parameters

- Science Applications International Corporation (SAIC), "Reclamation Cost Inputs for the Resource Allocation and Mine Costing Model," unpublished Final Working Paper prepared for U.S. Department of Energy, Energy Information Administration (November 1984)

\section{- Reclamation Costs}

- Science Applications International Corporation (SAIC, "Coal Preparation," unpublished Final Report prepared for U.S. Department of Energy, Energy Information Administration (June 1984)

- Preparation costs (basic cleaning costs)

- ICF Inc., "Coal and Electric Utilities Model Documentation," unpublished Draft Report (May 1980)

- Clean coal yields

- ICF Inc., "Further Analysis of Alternative New Source Performance Standards for New Coal-Fired Power Plants," unpublished Draft Report prepared for U.S. Environmental Protection Agency and U.S. Department of Energy (September 1978)

- $\quad$ Mine lives

- ICF Inc., Effects of Alternative New Source Performance Standards for Coal-Fired Electric Utility Boilers on the Coal Markets and on Utility Expansion Plans (1978)

\section{- Inaccessible reserves fractions}

- ICF Inc., "Coal and Electric Utilities Model Documentation," unpublished report (July 1977)

\section{- $\quad$ License fee}

- Paul P. Derienzo and Peter J. Phillips, "Steam Coal Preparation Economics," paper presented before the Second Symposium on Coal Preparation, Louisville, KY (October 19-21, 1976)

\section{- Clean coal yields}

- Mine Safety and Health Administration roof control plans

- Seam depth
- Various State mining reports

- Information used to supplement seam depth estimates

- Personal knowledge of analysts who developed the inputs

- Information used to supplement seam depth estimates (for some mines)

- Mine permit applications on file at State reclamation offices and Federal Office of Surface Mining library in Denver, CO

- Reclamation costs (earthmoving tasks)

- Mine permit applications on file at the Kentucky, Virginia, Illinois and Pennsylvania State regulatory agencies, and the Federal Office of Surface Mining library in Denver, $\mathrm{CO}$

- Reclamation costs (earthmoving tasks)

- Mine permit applications prepared by Science Applications International (SAIC) for clients in Kentucky and Tennessee

- Reclamation costs (earthmoving tasks)

- Ground control plans on file at Mine Safety and Health Administration, District and Subdistrict Offices

- Data used to estimate overburden ratio distribution parameters

- Illinois Department of Mines and Minerals, "Determination of Bonding Costs," (procedure description), (February 1983)

- Reclamation costs (estimates of the "typical" costs of revegetation in the Midwest)

- Illinois Department of Mines and Minerals, 1980 Annual Coal, Oil and Gas Report (May 1981).

- Data used to estimate overburden ratio distribution parameters

- Synergic Resources Corp. "Documentation of the Demonstrated Reserve Base of Coal in the United States," unpublished Final Report prepared for U.S. Department of Energy, Energy Information Administration (March 1982, Volume Two).

- Maximum depth representing the Demonstrated Reserve Base limit for surface mining, used in calculation of overburden ratio distribution parameters 
- Consolidated Omnibus Budget Reconciliation Act of 1986

- Black lung payments

- U.S. Department of the Interior

- Abandoned Mine Reclamation Fees

- Data used to estimate percentage of each region's production mined by operations on Federallyleased lands

- Federal coal royalty rates

- National Coal Association, Summary of Coal Severance and Production Taxes (November 1990)

- Severance taxes

- State Taxes on Coal: A Compendium of 1982 Statutes, Rand Corp. (1982)

- State and/or local taxes

- The State Tax Handbook as of October 1, Commerce Clearinghouse Inc. (1988 and 1989)

- Updates (in many regions) to State and/or local taxes

- Topical Law Reports, Commerce Clearinghouse Inc.

- State corporate income tax rates

- Mine Cost Service, Western Mine Engineering, Spokane, WA (1989)

- Updates (in many regions) to State and/or local taxes

- State corporate income tax rates (Alaska, Missouri and Montana)

- National Council on Compensation Insurance

- Current exposure insurance rates for the coal industry (most States)

- State Worker's Compensation offices and other State agencies

- Exposure insurance (some States)

- Caterpillar Tractor Co., Caterpillar Performance Handbook, Edition 11, (1980)

- Reclamation costs (equipment operating costs, and owning and labor costs for equipment not used by the model mines)
- Caterpillar Tractor Co., Caterpillar Performance Handbook, Edition 8, (1977)

- Reclamation costs (cycle times for haulage equipment)

- Skelly and Loy, "Abandoned Mine Land Prototype Reclamation Costs," unpublished report prepared for Kentucky Department for Natural Resources and Environmental Protection (1981)

- Reclamation costs (estimates of the "typical" costs of revegetation in Central Appalachia)

- Skelly and Loy, "Analysis of the Impact of Public Law 95-87 on Mining Performance," unpublished report prepared for U.S. Department of Energy (June 1979)

- Reclamation costs (permitting costs in the Midwest and West)

- Fred C. Hart Associates. "Reclamation Bond Estimation for Mine Plan Review," unpublished report prepared for U.S. Department of the Interior, Office of Surface Mining (August 1981)

- Reclamation costs (estimates of the "typical" costs of revegetation in Northern Appalachia)

- 1984 winning bids submitted by contractors to the Commonwealth of Pennsylvania for the reclamation of abandoned mine sites

- Reclamation costs (estimates of the "typical" costs of revegetation in Northern Appalachia)

- Engineering contractors that prepare applications for mining companies

- Typical permit application rates in Appalachia, used to calculate reclamation costs (permitting costs)

- U.S. Environmental Protection Agency, James J. Stukel, "Advanced Utility Simulation Model Analytical Documentation; State Level Model (Ver. 1.0), Appendix C--Coal Cleaning Methodology" (J.F. Skea and E.S. Rubin), EPA-600/8-88-071a (January 1989)

- Regression equations used to calculate preparation costs

- J.M Mutmanshky, et. al., "Mine Cost Analysis and Control," Handout for short course at Penn State University (April 9-11, 1990)

- Data on average unit productivity of a sample of 69 continuous miner operations, used to determine capital productivity adjustments factors 
- U.S. Department of the Treasury, Internal Revenue Service

- Federal corporate income tax rate.

\section{DOE Data Input Sources:}

Forms and Publications:

- Energy Information Administration, Annual Energy Review 1990, DOE/EIA-0384(90).

- Gross National Product deflators

- Energy Information Administration. Bituminous Coal and Lignite Production and Mine Operations--1978, DOE/EIA-0118(78).

- Average regional overburden ratios

- State-level labor productivity data, used to develop labor productivity adjustment factors

- Energy Information Administration, Coal Production, DOE/EIA-0118 (various years).

- Demonstrated Reserve Base of coal in the United States as of January 1, 1991, used to estimate total reserves

- Recoverable reserve data, used to develop estimates of committed reserves

- Data used to derive original mine size distribution parameters

- 1984 average regional overburden ratios

- 1989 State-level labor productivity data, used to develop labor productivity adjustment factors

- Production data, used in conjunction with coalmine capacity utilization data to estimate current production capacity and fraction of current production surface-mined

- Minemouth price data, used to estimate current price

- Energy Information Administration, Quarterly Coal Report, DOE/EIA-0121(90/2Q) (November 1990).

- State corporate income tax rates (West Virginia regions)

- Energy Information Administration, Coal Analysis File
- Btu and sulfur content data, used to distribute Demonstrated Reserve Base estimates by coal type

- Energy Information Administration, Forms EIA-7A, "Coal Production Report" (1983 Supplement))

- Total reserves

- Committed reserves

- 1980 recoverable reserve and production data, used to modify mine lives estimates for small surface mines

- 1980 data used to derive recovery factors

- Data used to derive adjustments to clean coal yield estimates (certain regions)

- 1984 data summarized to derive original mine size distribution parameters

- Seam thickness data for operating mines

- 1983 data used to estimate overburden ratio distribution parameters

- 1983 data used to estimate current production and price, and fraction of current production surfacemined

- Energy Information Administration, $R A M C$ Surface Mining Cost Equations Development, DOE/EIA-0432, prepared by Science Applications International Corporation (SAIC) (September 1983).

- Model mine cost equations, used to develop reclamation costs (earthmoving tasks)

- Reclamation costs (production capabilities for excavation equipment)

- Energy Information Administration, Documentation of the Reserve-Related Data Inputs to the Resource Allocation and Mine Costing Model, DOE/NBB-0026, prepared by Synergic Resources Corp. and Oak Ridge National Laboratory (September 1982).

- 1980 recoverable reserve and production data, used to modify mine lives estimates for small surface mines

- Recovery factors

- Mine size categories (surface mines and three smallest underground categories)

- Seam depth 
- Seam thickness

- Overburden ratio categories

- Energy Information Administration, Letter from Jack A. Simon, Chief of Illinois State Geological Survey, to Frank J. Doyle, then Dir. of EIA Eastern Energy Data Field Office, February 1981, published in Energy Information Administration, Demonstrated Reserve Base of Coal in the United States on January 1, 1979 (DOE/EIA-0280(79)).

- Inaccessible reserves fractions (Illinois surface reserves)

- Energy Information Administration, "Economic Growth Rate Assumptions for the 1992 AEO," Memorandum from Calvin Kilgore dated August 1, 1991

- Gross National Product deflators for the last year in the forecast period

- Energy Information Administration, "Update of Underground and Surface Mine Size Distribution Factors for AEO 1986," Memorandum from Mary K. Paull to Robert O. Crockett, December 2, 1986.

- Original mine size distribution parameters

Models and Other:

- Energy Information Administration, Resource Allocation and Mine Costing (RAMC) Model--Model definitions and assumptions

- Supply region

- Coal type

- Model mine regions

- Energy Information Administration, Review of forecasts generated by Coal Supply and Transportation Model (CSTM)

- Modified seam depth estimates

- Modified overburden ratio distribution parameters

- Modified reclamation costs

- Modified labor productivity adjustment factors

- Energy Information Administration, Energy Supply and Conversion Division Estimates

- Utility discount rate (estimated at 4.28 percent assuming a mixed capital structure)
- Coal industry rate of return (calculated from an assumed 8 percent rate of return)

General Output Descriptions: Coal supply curves for the Energy Information Administration's coal supply models. RAMC can be used to analyze the impact of changes in coal supply or costs caused by various factors.

Computing Environment:

- Hardware Used: IBM 3084

- Operating System: MVS/XA

- Language/Software Used: FORTRAN (G1 compiler)

- Memory Requirement: $1,024 \mathrm{~Kb}$

- Storage Requirement: $35 \mathrm{~Kb}$

- Estimated Run Time: Approximately 47 CPU seconds for one complete set of supply curves

- Special Features: None.

Independent Reviews Conducted:

- Model Quality Audit was conducted by the Office of Statistical Standards, November 1990.

- Independent Expert Review was conducted by Stanley Suboleski, July 1988.

Status of Evaluation Efforts by Sponsor: Recommendations from the RAMC Model Quality Audit are currently being incorporated into the RAMC.

\section{Revenue Requirements Modeling System (RRMS)}

Description: The RRMS is designed to estimate the impacts of various regulatory and economic policy variables on the revenue requirements of individual electric utilities. The model assesses the impact of changes in construction work in progress (CWIP), in rate base policies, capital structures, costs of capital, and demand on total estimated revenue requirements.

Last Model Update: February 1987.

Part of Another Model? The Single Asset Model (SAM) and the Revenue Requirements Model (RRM) combine to form the Revenue Requirements Modeling System (RRMS).

Model Interfaces: Financial Information Analysis System (FIAS). 
Sponsor:

- Office: Office of Coal, Nuclear, Electric and Alternate Fuels

- Division: Survey Management Division

- Branch: Electric Data Systems Branch, EI-521

- Model Contact: John Makens

- Telephone: 202-586-5629.

Documentation: Revenue Requirements Modeling System Documentation (RRMS), International Energy Associates, Limited, DOE/PE/70403 (March 1986).

- $\quad$ Volume I, Appendices A-C, March 1987

- Volume II, Appendices D-E, March 1987

- Volume III, Appendices F-H, March 1987

- Volume IV, Appendix I, December 1987.

Archive Media and Installation Manual(s):

- RRM85 - for the 1985 Annual Energy Outlook

- RRM85A - Archived for The President's Tax Proposal

- RRMS86 - for the Investor-Owned Electric Utilities Study.

Purpose: The RRMS estimates the cost of service of the electric operations of investor-owned electric utilities utilizing a simplified regulatory accounting framework. The RRMS specifically addresses the following components of revenue requirements: return on investment, depreciation expense, fuel expenses, nonfuel operations and maintenance expenses, and other (gross receipts) taxes.

Energy System Described by Model: RRMS produces electric utility financial information.

\section{Coverage:}

- Geographic: Single utility

- Time Unit/Frequency: Annual

- Product(s): Pro forma financial statements

- Economic Sector(s): Electric utilities.

Modeling Features:

- Model Structure: The methodology used in the RRMS consists of three basic steps. First, a general- ized cost-of-service framework is constructed. Second, an external data file interface provides the regulatory and economic environment to be studied by assigning values to key model parameters and variables. Finally, the user is able to produce standard preformatted reports designed to highlight the impacts of the assumed change in regulatory or economic environments.

- Modeling Technique: RRMS is a deterministic model that estimates certain financial relationships based on a simplified accounting framework represented by a series of linear equations.

- Special Features: RRMS uses either a SAS data set or a sequential card image file for input data. In addition, the current version of RRMS allows the user to assess the likely impacts of various provisions of the Tax Reform Act of 1986.

\section{Non-DOE Input Sources:}

- 1987 memo from Mark Inglis, ICF Inc. to John Conti, DOE/Energy Information Administration

- Construction Work in Progress (CWIP) in rate base.

\section{DOE Data Input Sources:}

Forms and Publications:

- Energy Information Administration, Form EIA-860, "Annual Electric Generator Report"

- Capacity

- Heat rates

- Company ID

- Plant ID

- Plant name

- Plant type

- Unit ID

- National Coal Model (NCM) coal region code

- Date plant comes on line

- Ownership type

- Percent owned by each company

- Residual type code

- Percent of year plant in service 
- Federal Energy Regulatory Commission, Form FERC-1, "Annual Report of Major Electric Utilities, Licensees and Others"

- Operations and maintenance costs (fixed and variable)

- Cost of capital

- Total assets

- Debt

- Accumulated deferred taxes

- Net electric plant

- $\quad$ Net nuclear fuel

- Net common plant

- Investments in subsidiaries

- Equity

- Electric construction work in progress (CWIP)

- Capitalization fractions

- Electric working capital

- Electric operations share factor

- Utility code

- Company name

- Ticker symbol

- Region

- Company share factor

- Value of assets net of allowance for funds used during construction (AFUDC)

- Transmission and distribution costs

Models and Other: None.

General Output Descriptions: The RRMS generates pro forma financial statements for evaluation of changes in electric utility policy and regulation. These data are used to produce a series of reports on a base case and a hypothetical case to summarize key financial output variables.
Computing Environment:

- Hardware Used: IBM 3084 or 360/370 (or equivalent)

- Operating System: OS or VS

- Language/Software Used: PL/1 and SAS (Ver. 5.16)

- Memory Requirement: $2,000 \mathrm{~Kb}$

- Storage Requirement: 3380 -- 100 tracks permanent, 1000 tracks temporary

- Estimated Run Time: On an IBM 3084QX operating under MVS/XA, typically less than 29 CPU seconds for one company.

- Special Features: None.

Independent Reviews Conducted:

- Model Quality Audit was conducted by the Office of Statistical Standards, August 1990.

- Independent Expert Review was conducted by $\mathbf{H}$. Thompson, August 1990.

Status of Evaluation Efforts by Sponsor: Ongoing.

\section{Short-Term Coal Analysis System (SCOAL)}

Description: SCOAL projects domestic coal production, imports, and exports six to eight quarters into the future, based on assumed trajectories of coal prices relative to prices of other fuels and coal demand by sector. All markets are defined at the national level except bituminous coal and lignite production, which are defined at the State level.

Last Model Update: January 1990.

Part of Another Model? No

Model Interfaces: SCOAL bases its projections on assumed relative energy price trajectories, domestic and foreign steel industry activity, domestic coal-based generation capacity and utilization, and other industry activity levels. The assumptions may be drawn from Data Resources, Inc., macroeconomic forecasts (or similar sources, e.g., Chase Econometrics); forecasts from the Short-Term Energy Outlook; forecasts from the Annual Energy Outlook, or other user specified sources. SCOAL's coal forecasts are used by the Short-Term Integrated Forecasting System and published in the Short-Term Energy Outlook. 
Sponsor:

- Office: Office of Coal, Nuclear, Electric and Alternate Fuels

- Division: Analysis and Systems Division

- Branch: Coal and Electric Branch, EI-532

- Model Contact: B. D. Hong

- Telephone: 202-254-5365.

\section{Documentation:}

- Energy Information Administration, Short-Term Integrated Forecasting System 1990 Model Documentation Report, DOE/EIA-M041(90) (Washington, DC, 1990).

- Energy Information Administration, Short-Term Integrated Forecasting System 1993 Model Documentation Report, DOE/EIA-M041(93) (Washington, DC, 1993).

- Previous Documentation: Energy Information Administration, Short-Term Coal Analysis System (SCOAL) Model Documentation Abstract, DOE/EIA0394 (EX) (Washington, DC, April 1983).

Archive Media and Installation Manual(s):

- SCOAL93A - Short-Term Energy Outlook 1st Quarter 1993

- SCOAL93B - Short-Term Energy Outlook 2nd Quarter 1993

- SCOAL93C - Short-Term Energy Outlook 3rd Quarter 1993

- SCOAL93D - Short-Term Energy Outlook 4th Quarter 1993

- SCOAL94A - Short-Term Energy Outlook 1st Quarter 1994

- SCOAL94B - Short-Term Energy Outlook 2nd Quarter 1994.

Purpose: SCOAL is used to support preparation of shortterm projections of bituminous coal and lignite production at the State level, and anthracite production, domestic imports of coal, and domestic and export demand at the national level.

Energy System Described by Model: Short-term coal supply at the national and State levels.
Coverage:

- Geographic: United States, regions, and 26 coalproducing States

- Time Unit/Frequency: Quarterly

- Product(s): Coal

- Economic Sector(s): U.S. coal industry and international sector.

Modeling Features:

- Model Structure: Five separate steps: national, regional, State, imports, and exports

- Modeling Technique: Ordinary least squares regressions.

- Special Features: SCOAL incorporates the primary economic and institutional factors that are assumed to determine quarterly domestic coal market balances. Its inclusion of relative energy price information on both the supply and demand sides makes it unique among short-term energy market models.

\section{Non-DOE Input Sources:}

- Bureau of Mines, Mineral Industry Yearbook

- Quarterly coal production (bituminous coal and lignite, and anthracite)

- Bureau of the Census, Monthly Report IM-145

- Monthly coal imports

- Bureau of the Census, Monthly Report EM-545

- Monthly steam coal and metallurgical coal exports

- International Iron and Steel Institute

- Pig iron production.

DOE Data Input Sources:

Forms and Publications:

- Energy Information Administration, Weekly Coal Production, DOE/EIA-0218 (Washington, DC).

- Quarterly coal production (bituminous coal and lignite, and anthracite)

- Energy Information Administration, Quarterly Coal Report, DOE/EIA-0121 (Washington, DC).

- Quarterly coal production (bituminous coal and lignite, and anthracite) 
- Coke industry coal consumption (quarterly) and stocks (at the end of the quarter)

- Other industries: steam coal consumption (quarterly) and stocks (at end of quarter)

- Energy Information Administration, Monthly Energy Review, DOE/EIA-0035 (Washington, DC).

- Foreign countries: oil prices

- Federal Energy Regulatory Commission, Form FERC-423, "Monthly Report of Cost and Quality of Fuels for Electric Plants"

- Fuel prices

- Energy Information Administration, Form EIA-3, "Quarterly Coal Consumption Report - Manufacturing Plants"

- Other industries: steam coal consumption (quarterly) and stocks (at end of quarter)

- Energy Information Administration, Form EIA-5, "Coke Plant Report"

- Coke industry coal consumption (quarterly) and stocks (at end of the quarter)

- Energy Information Administration, Form EIA-6, "Coal Distribution Report"

- Residential and commercial sectors: quarterly coal consumption

- Energy Information Administration, Form EIA-7A, "Coal Production Report"

- Coal prices

- Energy Information Administration, Form EIA-759, "Monthly Power Plant Report"

- Electric utilities: total quarterly coal consumption, coal stocks and quarterly generation

- Energy Information Administration, Form EIA-860, "Annual Electric Generator Report"

- Electric utilities: coal-based generating capacity

Models and Other:

- None.

General Output Descriptions: SCOAL is used by the Energy Information Administration's (EIA) Coal and Electric Branch on a continuing basis to prepare projections of quarterly domestic coal market balances from the present over a six-to-eight-quarter horizon. EIA's coal production forecasts (national and State level) are developed using SCOAL. Forecasts of coal production at the national level appear in EIA's Short-Term Energy Outlook (STEO).

\section{Computing Environment:}

- Hardware Used: IBM 3090, Mode 400E

- Operating System: MVS/XA

- Language/Software Used: Matrix Arithmetic Programming System (MAPS, Ver. 2) and Time Series Processor (TSP, Ver. 3.1)

- Memory Requirement: $1,999 \mathrm{~Kb}$

- Storage Requirement: 40 tracks

- Estimated Run Time: On an IBM 3090 operating under MVS/XA, approximately $110 \mathrm{CPU}$ seconds to run all SCOAL programs once

- Special Features: None.

Independent Reviews Conducted: Compliance with EIA Model Documentation for Seven Models: William Wamsley and Margaret Harpine, June 15, 1983.

Status of Evaluation Efforts by Sponsor: Most recent evaluation completed September 1984.

\section{Short-Term Integrated Forecasting System (STIFS)}

Description: STIFS is the system used to generate the forecasts of energy supply, demand and prices that are published in the Short-Term Energy Outlook. The model is a monthly dynamic simultaneous domestic energy market simulation model consisting of 105 core estimated forecasting relationships, numerous identities and various simulation roles covering demand and supply concepts for all major fuels (at the national level), including petroleum, natural gas, coal, electricity and renewable fuels.

Last Model Update: April 1995.

Part of Another Model? No.

Model Interfaces: Takes outputs from EIA's SCOAL, SNAPPS Models as exogenous for specified scenarios.

Sponsor:

- Office: Office of Energy Markets and End Use

- Division: Energy Markets and Contingency Information Division 
- Branch: Short-Term Forecasting and Contingency Branch, EI-621

- Model Contact: David Costello

- Telephone: 202-586-1468.

Documentation: Energy Information Administration, Model Documentation Report: Short-Term Integrated Forecasting System, DOE/EIA-M030 (Washington, DC, May 1993).

Archive Media and Installation Manual(s):

- STIFS0193 - Short Term Energy Outlook January 1993

- STIFS0493 - Short-Term Energy Outlook April 1993

- STIFS0793 - Short-Term Energy Outlook July 1993

- STIFS1093 - Short-Term Energy Outlook October 1993

- STIFS0194 - Short-Term Energy Outlook January 1994

- STIFS0494 - Short-Term Energy Outlook April 1994

- STIFS0794 - Short-Term Energy Outlook July 1994

- STIFS1094-Short-Term Energy Outlook October 1994.

Purpose: STIFS generates short-term (up to 8 quarters), monthly forecasts of U.S. supplies, demands, imports, exports, and stocks of various forms of energy. The models that constitute STIFS generate forecasts for various weather, price and macroeconomic scenarios.

Energy System Described by Model: U.S. energy production, consumption, imports, exports, stocks, and prices.

\section{Coverage:}

- Geographic: National

- Time Unit/Frequency: Monthly published results show only quarterly statistics plus forecasts for up to 2 years

- Product(s): Motor gasoline, distillate fuel oil, residual fuel oil, jet fuel, liquefied petroleum gases, other petroleum products, natural gas, coal, electricity, nuclear energy, hydroelectricity and gross and net energy consumption

- Economic Sector(s): Residential detail: Heating oil; natural gas; electricity. Commercial: fuel oil; natural gas, electricity. Industrial: fuel oil; natural gas; electricity; estimates of certain feedstock and other non-fuel uses of petroleum not readily available. Transportation detail: highway and air travel; motor gasoline; jet fuel and fuel oil (estimated bunkering and railroad).

\section{Modeling Features:}

- Model Structure: Accounting and algorithmic to balance supply and demand

- Modeling Technique: Includes accounting, algorithmic, econometric, and time trending techniques

- Special Features: STIFS is updated every quarter to produce new demand and supply forecast balances for the Short-Term Energy Outlook.

\section{Non-DOE Input Sources:}

- U.S. Department of Transportation, Federal Highway Administration, Highway Statistics Division, Traffic Volume Trends (monthly).

- Vehicle miles traveled

- Form 41 Data Base, collected by I.P. Sharp for U.S. Department of Transportation

- Revenue ton-miles

- Aircraft yield

- Aircraft load factor

- Available ton-miles

- Average aircraft efficiency

- Bureau of the Census X-11 program--seasonal adjustments

- Vehicle miles traveled

- Retail price--motor gasoline, distillate fuel oil, residual fuel oil

- Product supplied--total motor gasoline, No. 2 diesel fuel, liquefied petroleum gases (excluding ethane), kerosene-type jet fuel, petrochemical feedstocks

- Price of diesel fuel oil

- Price of natural gas--to industrial users and to electric utilities

- Wholesale prices--heating oil, motor gasoline

- Revenue ton-miles 
- $\quad$ Aircraft yield

- Average aircraft efficiency

- Demand for ethane

- Price of residual fuel to electric utilities

- Residential and commercial natural gas prices

- Residential electricity price

- Price of coal to electric utilities

- U.S. Department of Labor, Bureau of Labor Statistics, Consumer Price Index--Detailed Report.

- Retail price of motor gasoline

- Consumer price index

- U.S. Department of Labor, Bureau of Labor Statistics

- Producer price index

- U.S. Department of Labor, Bureau of Labor Statistics Producer Price Index (monthly issues)

- Producer price index for petroleum products

- DRI/McGraw-Hill, U.S. Central Data Base and Quarterly Model of the U.S. Economy

- Consumer price index projections

- Disposable personal income projections

- Industrial production, index, projections

- Chemical production index, projections

- Change in manufacturing, inventories, projections

- Raw steel production, projections

- AA bond rating for utilities, projections

- Real exchange rate plus projections

- Gross domestic product

- U.S. Department of Commerce, National Oceanic and Atmospheric Administration, Monthly State, Regional and National Heating Degree Days Weighted by Population

- New England heating degree-days

- Mid-Atlantic heating degree-days
- Population-weighted heating and cooling degreedays

- U.S. Federal Reserve System, Board of Governors, Statistical Release G 12.3

- Industrial production index (historical)

- Chemical production index (historical)

- Change in manufacturing inventories (historical)

- American Gas Association, Quarterly Report of Gas Industry Operations

- Number of customers, residential and commercial

- American Iron and Steel Institute, Raw Steel and Pig Iron Production Reports, AIS-7 (monthly reports)

- Raw steel production (historical).

\section{DOE Data Input Sources:}

Forms and Publications:

- Energy Information Administration, Costs and Indices for Domestic Oil and Gas Field Equipment and Production and Production Operations 1985 (Washington, $\mathrm{DC})$.

- Total number of wells drilled

- Amount of drilling expenditures

- Hole production factor

- Number of drilling permits

- Number of seismic crews working

- Energy Information Administration, Weekly Petroleum Status Report, DOE/EIA-0208 (Washington, DC).

- Retail price of motor gasoline

- Energy Information Administration, Database used in production of Monthly Energy Review, DOE/EIA-0035 (Washington, DC).

- Retail prices--motor gasoline, distillate and residual fuel oil

- Product supplied--total motor gasoline, No. 2 fuel oil (industrial sector), nonutility distillate and residual fuel oil

- Price of natural gas--for industrial users and to electric utilities 
- Electricity generation--total, nuclear, hydroelectric, petroleum, natural gas, coal

- Price of residual fuel to electric utilities

- Natural gas delivered--to residential and commercial consumers

- Natural gas used by pipelines

- Coal consumption--at electric utilities and by industrial users

- Price of imported crude oil

- Domestic and composite refiner acquisition cost of crude oil

- Natural gas wellhead price

- Residential and commercial natural gas prices

- Price of coal to electric utilities

- Last quarter's active rig count

- Wet gas production, dry gas production, imports, exports, supplemental gaseous fuels, injections to and withdrawals from working gas storage, total natural gas consumption, unaccounted for natural gas

- Prices to electric utilities--natural gas, residual fuel, coal

- Energy Information Administration, Database used in production of Petroleum Supply Monthly, DOE/EIA0109 (Washington, DC).

- Field production--crude oil, pentanes plus, LPGs, other hydrocarbons and alcohol

- Refinery output--motor gasoline, distillate, residual, jet fuel, LPGs, unfinished oils, other petroleum, pentanes plus

- Net imports--crude oil, motor gasoline, distillate, residual jet fuel, LPGs, unfinished oils, other petroleum, pentanes plus

- Refinery inputs--crude oil, unfinished oils, pentanes plus, LPGs, other petroleum, aviation gasoline blending components

- Product supplied--total petroleum, motor gasoline, distillate, residual, jet fuel, LPGs, other petroleum, crude oil, unleaded motor gasoline, petrochemical feedstocks, miscellaneous products, crude oil and pentanes plus
- Demand for ethane

- Closing stocks--crude oil, motor gasoline, distillate, residual, jet fuel, LPGs, other petroleum, motor gasoline blending components, unfinished oils, pentanes plus

- Crude oil losses

- Inputs to crude oil distillation units

- Refinery utilization

- Unaccounted for crude oil

- $\quad$ Refinery processing gain

- Energy Information Administration, Database used in production of Petroleum Marketing Monthly, DOE/EIA-0380 (Washington, DC).

- Imported price of crude oil, kerosene based jet fuel, wholesale motor gasoline, residential distillate

- Product supplied--No. 2 diesel fuel, No. 2 fuel oil (industrial sector)

- Price of diesel fuel oil

- Wholesale prices--heating oil, motor gasoline

- Average retail price for kerosene jet fuel

- Energy Information Administration, Monthly Energy Review, DOE/EIA-0035 (Washington, DC).

- Price of natural gas to electric utilities

- Price of residual oil to electric utilities

- Nonutility supply of electricity

- Net imports of electricity

- Heat content of natural gas--marketed (wet) production, dry production, electric utility consumption

- Heat content of coal--electric utility consumption

- Heat content of petroleum products--pentanes plus, LPGs, residual fuel oil, distillate fuel oil

- Heat rate (Btu per kilowatt hour)--coal, natural gas, residual fuel oil, distillate fuel oil

- Energy Information Administration, Quarterly Coal Report, DOE/EIA-0121 (Washington, DC). 
- Total consumption, production, imports, exports, primary stock change, secondary stock levels

- Coke production and consumption, and end-ofmonth coke stocks (January 1981 through December 1981)

- Coking coal demand

- Coal consumption--by industrial users, residential and commercial and total retail and general industry

- Coal production

- Net imports of coal

- Coal exports

- Energy Information Administration, Form EIA-860, "Annual Electric Generator Report"

- Coal-fired generating capacity

- Energy Information Administration, Coke and Coal Chemicals, DOE/EIA-0120 (Washington, DC, monthly issues)

- Coke production and consumption, and end-ofmonth coke stocks (December 1977 through December 1980)

- Energy Information Administration, Database used to produce Electric Power Monthly, DOE/EIA-0226 (Washington, DC).

- Generation of electricity from coal, natural gas, residual fuel oil, distillate fuel oil

- Total electricity generation

- Total electricity sales

- Net imports of electricity

- Consumption of fuels at electric utilities

- Residential electricity price

Models and Other:

- Energy Information Administration, Dallas Field Office

- Crude oil production

- Dry gas production

- Energy Information Administration, Office of Coal, Nuclear, Electric and Alternate Fuels
- Coal production and electricity generation by nuclear power, hydroelectric power, net imports of electricity, and nonutility generation.

General Output Descriptions: STIFS is used to generate short-term (up to 8 quarters), monthly forecasts of U.S. supplies, demands, imports, exports, and stocks of various forms of energy.

\section{Computing Environment:}

- Hardware Used: IBM 3084

- Operating System: OS/MVS2

- Language/Software Used: SAS, Ver. 6.07

- Memory Requirement: $2,000 \mathrm{~Kb}$

- Storage Requirement: 3380 disk -- Approximately 900 tracks to reload the files contained on the distribution tape, and a minimum of approximately 2000 tracks to store and execute the entire system.

- Estimated Run Time: On an IBM 3084QX operating under MVS/XA, 120 CPU seconds

- Special Features: None.

Independent Reviews Conducted: Independent Expert Reviews were conducted by G.S. Maddala and T. Mount, June 1991.

Status of Evaluation Efforts by Sponsor: None.

\section{Short-Term Nuclear Annual Power Production Simulation (SNAPPS)}

Description: SNAPPS forecasts the short-term monthly and annual electric power generation by U.S. commercial nuclear power plants. SNAPPS is a relatively simple, straightforward accounting model programmed in FORTRAN. The model consists of codes that provide accounting for each nuclear reactor's generation for the projection period.

Last Model Update: March 1991.

Part of Another Model? No.

Model Interfaces: The Nuclear Waste Fee System (NWFEE) - calculates nuclear waste fund revenues. The STEO Trialog - a microcomputer system component that is used as a tool for sensitivity analysis and documentation of short-term energy outlook data downloaded from SNAPPS mainframe output. 


\section{Sponsor:}

- Office: Office of Coal, Nuclear, Electric and Alternate Fuels

- Division: Analysis and Systems Division

- Branch: Nuclear Fuel Cycle Branch, EI-531

- Model Contact: Kenneth Chuck Wade

- Telephone: 202-254-5514.

Documentation:

- Short-Term Nuclear Annual Power Production Simulation Documentation, Version 4, (Washington, DC, June 1990).

- Short-Term Nuclear Annual Power Production Simulation Documentation, (Washington, DC, November 1984) and Addendum, (September 1986).

Archive Media and Installation Manual(s):

- SNAPP893- Archived for the Short-Term Energy Outlook, (July 1989)

- SNAP9103 - Archived for the Short-Term Energy Outlook, (January 1991)

- SNAP92Q4 - Archived for the Short-Term Energy Outlook, (4th Quarter 1992)

- SNAP93Q1 - Archived for the Short-Term Energy Outlook, (1st Quarter 1993)

- SNAP93Q2 - Archived for the Short-Term Energy Outlook, (2nd Quarter 1993)

- SNAP93Q3 - Archived for the Short-Term Energy Outlook, (3rd Quarter 1993).

Purpose: SNAPPS forecasts short-term monthly and annual generation of electricity by nuclear reactors in the United States.

Energy System Described by Model: Short-term electricity generation of domestic, commercial nuclear reactors.

\section{Coverage:}

- Geographic: Total United States, individual States, individual reactors, 10 Federal regions, or 4 Census regions

- Time Unit/Frequency: 18-month forecasts quarterly; 5-year forecasts annually, up to 10 years
- Product(s): Projections of electricity generation from nuclear power plants

- Economic Sector(s): Electric utilities which own or operate nuclear power plants.

\section{Modeling Features:}

- Model Structure: The model consists of codes that provide accounting for each nuclear reactor's generation over the projection period.

- Modeling Technique: The model develops reactor activity schedules, determining if the reactor is generating power or is in extended shutdown. Individual reactor monthly generation is computed by multiplying the designated capacity (net or gross) times the appropriate capacity factor times the hours the reactor operates in that month. For the near term, about 6 months, the values are calculated in a preprocessor that estimates system-wide monthly capacity factors by applying time-series techniques to historical data. The relationship between the monthly capacity factor and the percent of capacity on-line is modeled by a Box-Jenkins transfer function. For the remainder of the projection period, SNAPPS uses average, full-cycle capacity factors, which are functions of reactor type (BWR or PWR) and fuel cycle (1st, 2nd, or equilibrium). The resulting reactor generation values are then cumulated into monthly, annual and regional totals. The model contains the option of using positive refueling times in lieu of seasonality factors.

- Special Features:

- Allows the user to project either gross or net electricity generation

- Reports aggregate operating capacity factors

- May be run either in a reactor-specific or an aggregate mode.

\section{Non-DOE Input Sources:}

- Nuclear Regulatory Commission, NRC Operations Center Plant Status Report (updated weekly)

- Scheduled outage data (start date and duration)

- Nuclear Regulatory Commission, Operating Data Reports

- Historical generation data (reactor name, date, historical generation and type of generation) 
- David Andress, Washington Consulting Group, Analysis of Capacity Factors, (March 1990)

- Cycle-specific data (cycle capacity factor)

- Generic parameters (monthly capacity factor adjustment (seasonality) factors)

- David Andress, System Sciences, Analysis of Capacity Factors, (September 1984)

- Cycle-specific data (cycle capacity factor)

- Generic parameters (monthly capacity factor adjustment (seasonality) factors).

\section{DOE Data Input Sources:}

Forms and Publications:

- Energy Information Administration, Form EIA-759, "Monthly Power Plant Report"

- Historical generation data (1986 on: reactor name, date, historical generation and type of generation)

- Office of Civilian Radioactive Waste Management, Form RW-859, "Nuclear Fuel Data"

- Cycle-specific data (cycle number, cycle start date, cycle generation time, cycle capacity factor, cycle full-power days, refueling start date and refueling time)

- Energy Information Administration, Form EIA-860, "Annual Electric Generator Report"

- Basic reactor characteristics (reactor capacities)

Models and Other:

- Energy Information Administration, International Nuclear Model, (INM) maintained by the Office of Coal, Nuclear, Electric and Alternate Fuels

- Basic reactor characteristics (reactor type, reactor name, reactor capacities, DOE region, start dates (initial criticality, first electricity and commercial operation), State code and reactor retirement date)

- Energy Information Administration, Office of Coal, Nuclear, Electric and Alternate Fuels

- Generic parameters

- Default capacity factor

- Default full power days
- Default refueling time

- Monthly capacity factor adjustment (seasonality) factors

- Annual capacity factor adjustment (trend) factors.

\section{General Output Descriptions:}

- Monthly, quarterly and annual forecasts of the total electricity generated by the Nation's reactors

- Monthly and annual forecasts of electricity generated by each reactor

- Monthly and annual forecasts of aggregate operating capacity factors

- Reactor operating characteristics.

Computing Environment:

- Hardware Used: IBM 3084QX

- Operating System: MVS/XA

- Language/Software Used: VS FORTRAN (Uses the G-1 compiler)

- Memory Requirement: $1,600 \mathrm{~Kb}$

- Storage Requirement: 3380 disk--5Mb for model and data

- Estimated Run Time: 7 CPU seconds

- Special Features: None.

Independent Reviews Conducted:

- Independent Expert Review of Short-Term Nuclear Annual Power Production Simulation Model (SNAPPS), John L. Solow, Department of Economics, College of Business Administration, University of Iowa, Iowa City, IA 52242, May 1990.

- Model Quality Audit was conducted by the Office of Statistical Standards, May 1990.

- Short-Term Nuclear Annual Power Production Simulation Model Documentation Review, Cyrus Baghelai, Applied Management Sciences, November 20, 1983.

Status of Evaluation Efforts by Sponsor: None. 


\section{Uranium Market Model (UMM-PC)}

Description: UMM-PC projects prices, production, imports, inventory, capital expenditures, and employment in the uranium mining and milling industry. The model considers every major production center and utility on a worldwide basis (with centrally planned economies considered in a limited way).

Last Model Update: August 1994.

Part of Another Model? None.

Model Interfaces: None.

Sponsor:

- Office: Office of Coal, Nuclear, Electric and Alternate Fuels

- Division: Analysis and Systems Division

- Branch: Nuclear Fuel Cycle Branch, EI-531

- Model Contact: Ercan Tukenmez

- Telephone: 202-254-5544.

Documentation: Energy Information Administration, Documentation of the Uranium Market Model (UMM-PC), DOE/OR-21400-H11 (Washington, DC, January 1993).

Archive Media and Installation Manual(s):

- ORUMMPC - for the 1987 Viability Study.

- ORUMM89 - Archived for Domestic Uranium Mining and Milling Industry 1988: Viability Assessment

- ORUMM90 - Archived for Domestic Uranium Mining and Milling Industry 1989: Viability Assessment

- ORUMM91 - Archived for the Domestic Uranium Mining and Milling Industry 1990: Viability Assessment

- ORUMM92 - Archived for the report, Domestic Uranium Mining and Milling Industry 1991

- UMM93 - Archived for the report, Domestic Uranium Mining and Milling Industry 1992

- UMM94 - Archived for the report, World Nuclear Capacity and Fuel Cycle Requirements.

Purpose: The UMM-PC is used to model international uranium mining, milling, and marketing activities.

Energy System Described by Model: International uranium mining and milling.

\section{Coverage:}

- Geographic: World

- Time Unit/Frequency: Annually

- Product(s): Natural uranium

- Economic Sector(s): Buyer and producer regions.

Modeling Features:

- Model Structure: Uranium supplied by the mining and milling industry is matched to the demand for uranium by electric utilities possessing nuclear power plants. Equations are listed in Chapter II, 'Technical Specifications,' of the Model Documentation Report.

- Modeling Technique: Microeconomic simulation model

- Special Features: None.

Non-DOE Input Sources:

- Fuel-Trac Report on Requirements and Commitment Status for U308 for Country and Country Group, Nuclear Assurance Corporation (NAC), February 1994.

- Country name

- Country ID number

- Utility ID number

- Country production

- Net imports

- First year of import quota

- Utility name

- Inventories

- Inventory to satisfy inventory demand

- Inventory available for sale

- Import quota

- Detailed U308 Commitment Status by Supplier, Nuclear Assurance Corporation (NAC) (February 1994).

- Production center ID

- Unmet domestic demand 
- Production committed to this utility in a simulation year

- Production center name

- Pointer to country of production center

- Year when production starts

- Initial production start year

- Size of operation

- Production amount available for sale

- Year in which production was sold

- Country committed to sell to

- Estimates of Behavior, Management and Market Data, Nuclear Resources International (February 1984), for ORNL

- Years of desired uranium inventory.

\section{DOE Data Input Sources:}

\section{Forms and Publications:}

- Energy Information Administration, Form EIA-858, "Uranium Industry Annual Survey"

- Inventories

- Energy Information Administration, Domestic Uranium Mining and Milling Industry 1992 Viability Assessment, DOE/EIA-0477(92) (Washington, DC, December 1992)

- Spot price

- Contract price

- Employment

- Capital expenditures

- Acceptable selling price

Models and Other:

- None.

\section{General Output Descriptions:}

- World spot price

- Domestic or region-specific spot prices

- World contract price
- Domestic or region-specific contract prices

- Production from every major production center in the world

- Production on a country- or region-specific basis

- Net imports into each region

- Utilities' inventories, tabulated from inventories of individual utility groups on a worldwide basis

- Annual drawdown of utilities' inventories

- Capital expenditures by the mining and milling industry

- Employment in the mining and milling industry.

Computing Environment:

- Hardware Used: IBM-compatible personal computer

- Operating System: MS-DOS, Ver. 2.0 or greater

- Language/Software Used: Pascal (compiled \& linked using Borland Turbo Pascal 4.0)

- Memory Requirement: 640Kb

- Storage Requirement: $630 \mathrm{~Kb}$

- Estimated Run Time: On a Compaq Deskpro 386/40 operating at $16 \mathrm{MHz}$ under DOS 3.2 with an Intel 80287 coprocessor, between 8 and 9 seconds

- Special Features: Model requires a math coprocessor and a hard disk plus a version of DOS that is 2.1 or greater.

Independent Reviews Conducted: None.

Status of Evaluation Efforts by Sponsor: None.

\section{Wellhead Gas Productive Capacity Model (GASCAP)}

Description: GASCAP estimates the historical wellhead productive capacity of natural gas for the lower 48 States and projects the productive capacity for 3 years. The ShortTerm Energy Outlook (STEO) output for low, base and high cases is used to estimate the number of active rigs and oil and gas well completions. The projected oil production is used to estimate the oil-well gas production (which is assumed to be producing at capacity) using a constant gas-oil ratio. The gas demand is also taken from STEO. The difference between demand and oil-well gas production is 
assumed to be the gas-well gas demand and the production as long as capacity exceeds demand.

Last Model Update: September 1994.

Part of Another Model? No.

Model Interfaces: GASCAP projections are based on the gas demand projected by STEO.

\section{Sponsor:}

- Office: Office of Oil and Gas

- Division: Reserves and Natural Gas Division

- Branch: Reserves and Production Branch, EI-443

- Model Contact: James N. Hicks

- Telephone: $214-767-2200$.

Documentation: Energy Information Administration, Model Documentation for the Wellhead Gas Productive Capacity Model, DOE/EIA-M052, (Washington, DC, March 1995).

Archive Media and Installation Manual(s): GASCAP94 Archived for the Natural Gas Productive Capacity for the Lower 48 States: 1980 through 1995.

Purpose: GASCAP is used to project the natural gas wellhead productive capacity for the lower 48 States. It also allows quantification of the available productive capacity and the projected capacity under differing future scenarios. Results are published in the recurring EIA report, Natural Gas Productive Capacity for the Lower 48 States.

Energy System Described by Model: GASCAP measures and predicts wellhead natural gas productive capacity.

\section{Coverage:}

- Geographic: 10 area/State subdivision of the lower $\mathbf{4 8}$ States

- Time Unit/Frequency: Monthly estimates of natural gas productive capacity are projected over 3 years for each subdivision, and are summed for the lower 48 States under varying scenarios.

- Product(s): Natural gas

- Economic Sector(s): Lower 48 States and Subdivisions.
Modeling Features:

- Model Structure: The model consists of a series of statistical analysis system (SAS) procedures utilizing a modified rate of production versus cumulative production (Rate-cum) equation. It also consists of a series of Lotus 1-2-3 spreadsheets that interlock with mainframe outputs.

- Modeling Technique: Peak production rates and cumulative production were determined for wells that first had production in a vintage year for that year and each successive year, e.g., peak rates and cumulative production were determined for 1978, 1979...1992 for wells that first had production in 1978; 1979, $1980 . .1993$ for wells that first had production in 1979; etc.

- Special Features: Several personal computer (PC) spreadsheet programs are used to assimilate the demand and well completion data that are input for the projection programs in GASCAP. Different scenarios can be analyzed by changing the assumed input parameters; i.e., oil production, active rigs, gas demand, etc.

\section{Non-DOE Input Sources:}

- Dwight's Energy Data, Inc., well history tapes, Richardson, TX, 1992

- Monthly natural gas production by well

- Cumulative production to date by month

- Baker Hughes, Incorporated

- Monthly rotary rig counts

- Energy Information Administration computations based on well reports submitted to the Petroleum Information Corporation

- Oil and gas wells drilled.

DOE Data Input Sources:

- Energy Information Administration, Natural Gas Annual, DOE/EIA-0131 (Washington, DC, annually).

- Marketed wet natural gas production by State

- Gross gas production by State

- Oil well gas production by State 
- Energy Information Administration, Natural Gas Monthly, DOE/EIA-0130 (Washington, DC, January 1980 through December 1993).

- State marketed gas production

- Energy Information Administration, Monthly Energy Review, DOE/EIA-0035 (Washington, DC, monthly).

- Crude oil production

- World oil price (imported refiner acquisition cost)

- Marketed gas production

- Natural gas wellhead price

- Energy Information Administration, Short-Term Energy Outlook, DOE/EIÄ-0202 (Washington, DC, quarterly).

- Marketed dry natural gas demand for low, base, and high case.

General Output Descriptions: GASCAP produces wellhead production and capacity estimates for each subdivision and for each case submitted.

\section{Computing Environment:}

- Hardware Used: IBM-compatible personal computer

- Operating System: DOS

- Language/Software Used:

FORTRAN/SAS/COBOL; Lotus 1-2-3, Ver. 2.2; Harvard Graphics, Ver. 2.3; WordPerfect, Ver. 5.1

- Memory Requirement: $2 \mathrm{Mb}$

- Storage Requirement: $3 \mathrm{Mb}$

- Estimated Run Time: 10 minutes real time

- Special Features: None.

Independent Reviews Conducted: None.

Status of Evaluation Efforts by Sponsor: None.

\section{World Energy Projection System (WEPS-PC)}

Description: WEPS-PC is an integrated set of personalbased spreadsheets containing data compilations, assumption specifications, descriptive analysis procedures, and projection models. The WEPS accounting framework in- corporates projections from independently documented models and assumptions about the future energy intensity of economic activity (ratios of total energy consumption divided by gross domestic product (GDP) and about the rate of incremental energy requirements met by natural gas, coal, and renewable energy sources (hydroelectricity, geothermal, solar wind, biomass, and other renewable sources).

WEPS-PC provides projections of total world primary energy consumption, as well as projections of energy consumption by primary energy type (oil, natural gas, coal, nuclear, and hydroelectric and other renewable sources), and projections of net electricity consumption. Carbon emissions resulting from fossil fuel use are derived from the energy consumption projections. All projections are computed in 5-year intervals through 2010. For both historical series and projections series, WEPS-PC provides analytical computations of energy intensity and energy elasticity (the percentage change in energy consumption per percentage change in GDP).

Last Model Update: January 1995.

Part of Another Model? No.

Model Interfaces: Accepts or considers outputs from the World Integrated Nuclear Evaluation System (WINES); International Energy Module (Submodule of NEMS); International Nuclear Model, PC Version (PCINM); and the Coal Export Submodule of the National Energy Modeling System.

Sponsor:

- Office: Office of Integrated Analysis and Forecasting

- Division: Energy Demand and Integration Division

- Branch: International, Economic and Integrated Forecasting Branch, EI-812

- Model Contact: Linda Doman

- Telephone: 202-586-1041.

Documentation: Energy Information Administration, World Energy Projection System Model Documentation (Washington, DC, June 1992).

Archive Media and Installation Manual(s):

- WEPS92- World Energy Projection System 1992 for the International Energy Outlook 1992 and the Annual Energy Outlook 1992

- WEPS93 - World Energy Projection System 1993 for the International Energy Outlook 1993

- WEPS94 - for the International Energy Outlook 1994. 
Purpose: WEPS-PC projects total primary energy consumption, energy consumption by primary energy source, carbon emissions, and net electricity consumption, WEPSPC provides an accounting framework that produces consistent world energy consumption balances from diverse sources of information.

Energy System Described by Model: Oil, gas, coal, nuclear, other (hydro and geothermal), electricity, and carbon emissions.

\section{Coverage:}

- Geographic: World by selected countries and regions

- Time Unit/Frequency: Projections of production by year and of consumption by 5 -year intervals through the year 2010

- Product(s): Units include million barrels per day (oil), trillion cubic feet (gas), million short tons (coal), billion kilowatt hours (nuclear and electricity), and quadrillion Btu (Hydroelectricity and other renewable energy sources)

- Economic Sector(s): Total end use.

\section{Modeling Features:}

- Model Structure: The model structure is an accounting framework of relationships concerning energy consumption and production, economic growth, conservation and efficiency gains, production capacities, available reserves, and recoverable resources that are extended to the year 2010 considering historical trends, planned construction, model projections, and other related assumptions.

- Modeling Technique: The major technique used in the WEPS-PC accounting framework is to project total energy consumption by region based on an assumed relationship to economic growth as measured by gross domestic product (GDP). Projections of all other energy sources are made consistent with projected total energy and subject to estimates of available resources. Econometric techniques are not used to determine changes in relationships over the projection period.

- Special Features: None.

\section{Non-DOE Input Sources:}

- Charles D. Masters, et al., U.S. Geological Survey, "World Resources of Crude Oil and Natural Gas," Proceedings from 13th World Petroleum Congress, 1991

- Undiscovered natural gas resources
- Remaining oil resources

- International Energy Agency (Paris), Coal Information and Electricity Information

- Adjustment factor to electric generation efficiency

- International Energy Agency, Energy Statistics and Balances of Non-OECD Countries

- Electricity information

- International Energy Agency (Paris), Energy Balances of OECD Countries

- Consumption of energy source (oil, gas, coal, nuclear, other) by sector

- International Energy Agency (Paris), Energy Statistics of OECD Countries

- Total electricity consumption

- Amount of energy source (oil, gas, coal, nuclear, other) used for electricity generation

- Amount of energy source (oil, gas, coal) used for all purposes other than electricity generation

- PennWell Publishing Co., Oil and Gas Joumal

- Proved reserves for oil and natural gas

- Reed Business Publishing, International Water Power and Dam Construction

- Hydropower construction plans

- United Nations, Energy Statistics Yearbook

- Hydro and geothermal capacity utilization rates

- The WEFA Group, World Economic Outlook

- Gross domestic product annual growth rate

- The WEFA Group, World Economic Service Historical Data

- Gross domestic product

- Gross domestic product annual growth rate.

- PlanEcon, Review and Outlook for Eastern Europe,

- Review and outlook for Former Soviet Union GDP growth in Eastern Europe and Former Soviet Union. 
DOE Data Input Sources:

- Energy Information Administration, Annual Energy Outlook (Washington, DC, annually).

- Consumption of energy source (oil, gas, coal, nuclear, other)

- Energy Information Administration, World Nuclear Outlook (Washington, DC, annually).

- Nuclear power generating capacity

- Percentages of nuclear power generating capacity utilized

- Energy Information Administration, International Energy Annual (Washington, DC, annually).

- Oil consumption in standard units

- Nuclear energy consumption in standard units

- Natural gas consumption in standard units

- Coal consumption in standard units

- Hydroelectricity and other renewable sources

- Standard unit (Quadrillion Btu) conversion factor for energy source (oil, gas, coal, nuclear)

- Nuclear power imported or (negative value) exported

- Total net consumption of electricity.

General Output Descriptions: Primary energy and end-use energy consumption by specific energy source (oil, natural gas, coal, nuclear, other, and electricity), oil production, and oil capacity by country or country group and specified years.

\section{Computing Environment:}

- Hardware Used: IBM-compatible personal computer

- Operating System: DOS, Ver. 4.0

- Language/Software Used: Lotus 1-2-3, Ver. 2.2

- Memory Requirement: The world energy consumption spreadsheet programs require about $2.3 \mathrm{Mb}$ of hard-disk memory. To run the world energy consumption base-case spreadsheet requires about $640 \mathrm{~Kb}$ of RAM; and the electricity consumption spreadsheet about $250 \mathrm{~Kb}$ of RAM.

- Storage Requirement: $3 \mathrm{Mb}$
- Estimated Run Time: Given the incorporation of base-case assumptions, world energy consumption spreadsheet programs solve in about 5 seconds. The process of generating associated range values requires from 5 to 10 minutes of user time.

- Special Features: None.

Independent Reviews Conducted: None.

Status of Evaluation Efforts by Sponsor: No evaluation currently being undertaken.

\section{World Integrated Nuclear Evaluation System (WINES-PC)}

Description: WINES-PC is an aggregate demand-based partial equilibrium model used by the Energy Information Administration (EIA) to project long-term domestic and international nuclear energy requirements. WINES-PC follows a top-down approach in which economic growth rates, delivered energy demand growth rates, and electricity demand are projected successively to ultimately forecast total nuclear generation and nuclear demand capacity. WINES-PC could potentially be used to produce forecasts for any country or region in the world. Presently, WINES-PC is being used to generate long-term forecasts for the United States and for all countries with commercial nuclear programs in the world, excluding countries located in centrally planned economic areas. Projection for the United States are developed for the period from 2010 through 2030, and for other countries for the period starting in 2000 or 2005 (depending on the country) through 2010.

WINES-PC serves as a flexible tool with which to assist the U.S. Department of Energy (DOE) program offices and other Government agencies in their analyses of long-term nuclear energy demand and supply, and to support cooperative efforts between the United States and the Nuclear Energy Agency (NEA) of the Organization for Economic Cooperation and Development (OECD), the International Energy Agency (IEA), and the International Atomic Energy Agency (IAEA). WINES-PC is used to develop long-term projections of nuclear capacity and generation published annually by EIA in World Nuclear Capacity and Fuel Cycle Requirements. These projections are provided to the Office of Civilian Radioactive Waste Management (OCRWM) of DOE for use in estimating nuclear waste fund revenues, and to aid in planning the disposal of nuclear waste. In addition, the projections support other reports published annually by EIA such as Domestic Uranium Mining and Milling Industry: Viability Assessment, and World Nuclear Fuel Cycle Requirements.

Last Model Update: December 1991.

Part of Another Model? No. 
Model Interfaces: None.

Sponsor:

- Office: Office of Integrated Analysis and Forecasting

- Division: Energy Supply and Conversion Division

- Branch: Nuclear and Electricity Analysis Branch, EI821

- Model Contact: Laura Church

- Telephone: 202-586-1494.

Documentation:

- Energy Information Administration, Wines Model Documentation, DOE/EIA-M049 (Washington, DC, December 31, 1991).

- Energy Information Administration, Model Documentation of the World Integrated Nuclear Evaluation System, E.H. Pechan and Associates, (Washington, DC, June 1985).

- Volume 1, Model Documentation

- Volume 2, Model Description

- Volume 3, Executive Summary

- Energy Information Administration, Model Documentation of the World Integrated Nuclear Evaluation System (Washington, DC, December 1984).

- Executive Summary

- $\quad$ Model Overview, Volume 1, DOE/EI/19656-1/1

- $\quad$ Model Description, Volume 2, DOE/EI/19656-1/2

- Data Documentation, Volume 3 Part A, DOE/EI/19656-1/3A

- Data Documentation, Volume 3 Part B, $\mathrm{DOE} / \mathrm{EI} / 19656-1 / 3 \mathrm{~B}$

- Model Abstract, Volume 4, DOE/EI/19656-1/4

- Energy Information Administration, World Integrated Nuclear Evaluation System (WINES) User's Guide and Model Documentation, MATHTECH, Inc. (Washington, DC, April 1983).

Archive Media and Installation Manual(s):

- WINES90 - for the report, Commercial Nuclear Power 1990
- WINES91 - for the report, Commercial Nuclear Power 1991

- WINES91D - archived for purposes of documentation

- WINES92 - for the report, World Nuclear Capacity and Fuel Cycle Requirements.

Purpose: The primary objective of WINES-PC is to project long-term annual nuclear generation and installed nuclear generating capacity worldwide.

Energy System Described by Model: Estimates are made of country-specific economic growth rates, delivered energy demand growth rates, delivered energy demand, electricity generation, nuclear generation, and nuclear capacity.

Coverage:

- Geographic: Countries comprising the world outside of centrally planned economic areas with commercial nuclear programs.

- Time Unit/Frequency: WINES-PC is designed to forecast in five-year intervals.

- Product(s): Gross domestic product or gross national product growth rates, aggregate delivered energy demand growth rate, aggregate delivered energy demand, electricity generation, nuclear generation, and nuclear capacity.

- Economic Sector(s): Country-specific aggregate demand.

Modeling Features:

- Model Structure: Basic four equations linked successively representing economic growth, aggregate energy demand growth, and electricity and nuclear generation requirements.

- Modeling Technique: Simulation based on long-term growth relationships and logistic market penetration functions. Economic growth rates based on labor supply and productivity growth rates, energy demand growth defined by a Cobb-Douglas demand function based on economic growth and aggregate energy price growth, and electricity and nuclear generation determined with logistic market penetration functions.

- Special Features: Long-term, highly aggregated model using logistic curves to estimate market penetration for electricity and nuclear generation.

\section{Non-DOE Input Sources:}

- Gregory Spencer, U.S. Department of Commerce, Bureau of the Census, Projections of the Population of 
the United States, by Age, Sex and Race: 1988 to 2080,

Series P-25, No. 1018, Washington, DC, January 1989

- Labor-age population growth rates (U.S.)

- M.T. Vu, World Bank, Short-Term Population Projection, 1980-2000 and Long-Term Projection, 2000 to Stationary Stage by Age and Sex for All Countries of the World, Washington, DC, July 1984

- Labor-age population growth rates (foreign)

- World Bank, World Development Report

- Classification of per capita income used to adjust price and income elasticities of energy demand over time (non-OECD nations)

- U.S. Department of Labor, Bureau of Labor Statistics, Employment and Eamings,

Washington, DC, January 1991

- Labor force participation growth rate (U.S.)

- U.S. Department of Labor, Bureau of Labor Statistics, Handbook of Labor Statistics, (Washington, D.C., various annual issues)

- Historical productivity data used to estimate labor productivity growth rate (U.S.)

- Organization for Economic Cooperation and Development, Department of Economics and Statistics, Labour Force Statistics, Paris, 1990

- Labor force participation growth rate (OECD nations)

- Organization for Economic Cooperation and Development, Historical Statistics--OECD Economic Outlook, Paris (various annual issues)

- Labor productivity growth rate (OECD nations)

- Historical energy prices used to estimate delivered energy price growth rate (OECD) nations)

- Historical energy consumption, price and growth data used to estimate price and income elasticities of energy demand (OECD nations)

- Organization for Economic Cooperation and Development, Energy Prices and Taxes, Paris (various quarterly issues)

Historical energy prices used to estimate delivered energy price growth rate (OECD nations)
- Historical energy consumption, price and growth data used to estimate price and income elasticities of energy demand (OECD nations)

- Organization for Economic Cooperation and Development, International Energy Agency, IEA Statistics: World Energy Statistics and Balances, Paris, (June 1991)

- Historical energy consumption, price and growth data used to estimate price and income elasticities of energy demand (OECD nations)

- Historical electrical and nuclear shares data used to estimate electrical and nuclear share asymptotic limits, and electrical and nuclear halving factors (foreign)

- Organization for Economic Cooperation and Development, International Energy Agency, Energy Policies and Programs of IEA Countries: 1989 Review, (Paris, 1990)

- Energy price forecasts used to estimate delivered energy price growth rate (OECD nations)

- Organization for Economic Cooperation and Development, Nuclear Energy Data, (Paris, 1991)

- Historical nuclear shares data and nuclear generation forecasts used to estimate nuclear share asymptotic limit and nuclear halving factor (foreign)

- Organization for Economic Cooperation and Development, Nuclear Energy Agency, Summary of Nuclear Power and Fuel Cycle Data in OECD Member Countries, (Paris, March 1983)

- Base year aggregate energy demand

- Organization for Economic Cooperation and Development, Nuclear Energy Agency, Tabulation of WPNFCR Questionnaire Responses from OECD Member Countries, (Paris, December 1980)

- Base year aggregate energy demand

- Organization for Economic Cooperation and Development, Nuclear Energy Agency, Tabulation of WPNFCR Questionnaire Responses from Non-OECD States, (Paris, July 1980).

- Base year aggregate energy demand

- International Labour Office, Labour Force Estimates, (Geneva, Switzerland, 1977).

- Labor force participation growth rate (nonOECD nations) 
- Labor productivity growth rate (non-OECD nations)

- United Nations, 1981 Statistical Yearbook of the United Nations (New York, 1983).

- Base year aggregate energy demand

- United Nations, 1980 Yearbook of World Energy Statistics (New York, 1982).

- Base year aggregate energy demand.

DOE Data Input Sources:

Forms and Publications:

- Energy Information Administration, Annual Energy Outlook, DOE/EIA-0383 (Washington, DC, annual).

- Energy price forecasts used to estimate delivered energy price growth rate (U.S.)

- Historical energy consumption, price and growth data used to estimate price and income elasticities of energy demand (U.S.)

- Base year aggregate energy demand

- Historical electrical and nuclear shares data used to estimate electrical and nuclear share asymptotic limits, and electrical and nuclear halving factors (U.S.)

- Energy Information Administration, Annual Energy Review, DOE/EIA-0384 (various issues) (Washington, $\mathrm{DC}$, annual).

- Historical energy prices used to estimate delivered energy price growth rate (U.S.)

- Historical energy consumption, price and growth data used to estimate price and income elasticities of energy demand (U.S.)

- Base year aggregate energy demand

- Historical electrical and nuclear shares data used to estimate electrical and nuclear share asymptotic limits, and electrical and nuclear halving factors (U.S.)

- Energy Information Administration, Commercial Nuclear Power: Prospects for the United States and the World, DOE/EIA-0438 (Washington, DC, 1990 and 1991 issues).

- Historical nuclear shares data and nuclear generation forecasts used to estimate nuclear share asymptotic limit and nuclear halving factor (U.S.)

- Nuclear generation capacity factor

- Energy Information Administration, Improving Technology: Modeling Energy Futures for the National Energy Strategy, Service Report SR/NES/90-01, January 1991

- Energy price forecasts used to estimate delivered energy price growth rate (U.S.)

Models and Other:

- None.

General Output Descriptions: WINES-PC provides projections of both installed nuclear capacity and the intermediate variables necessary to project nuclear capacity by nation or aggregated by selected geographic and economic criteria. Output reports are created for two reference-case scenarios: an Upper (MID) Reference Case, and a Lower (LOW) Reference Case. Projections are generated for the following variables:

- GDP or GNP Growth Rate

- Delivered Energy Growth Rate

- Delivered Energy Demand

- Electrical Generation

- Nuclear Generation

- Nuclear Installed Capacity.

Computing Environment:

- Hardware Used: IBM-compatible personal computer

- Operating System: MS-DOS

- Language/Software Used: VS FORTRAN, Ver. 3.31

- Memory Requirement: 640Kb RAM

- Storage Requirement: $600 \mathrm{~Kb}$

- Estimated Run Time: No longer than 5 minutes

- Special Features: None.

Independent Reviews Conducted:

- WINES Model Analysis, Decision Analysis Corporation of Virginia; Vienna, Virginia; January 1987. 
- Independent Expert Review was conducted by James Quirk, Grantsburg, Wisconsin, April 1990.

- Model Quality Audit was conducted by the Office of Statistical Standards, April 1990.

- WINES Model Analysis, Decision Analysis Corporation of Virginia; Vienna, Virginia; August 1991.
- WINES Model Analysis (OECD Countries), Decision Analysis Corporation of Virginia; Vienna, Virginia; November 1991.

Status of Evaluation Efforts by Sponsor: Evaluation efforts are underway as development continues. 

Appendix A

Major Modeling

Systems and

Contributing Models 



\section{Appendix A}

\section{Major Modeling Systems and Contributing Models}

\section{Models of the National Energy Modeling System (NEMS)}

Coal Market Module (CMM)

Commercial Sector Demand Module (CDM)

Data Resources, Inc., Model of the U.S. Economy (DRI)

Electricity Market Module (EMM-NEMS)

Industrial Demand Module (IDM)

Integrating Module (INT)

International Energy Module (IEM)

Macroeconomic Activity Module (MAM)

Natural Gas Transmission and Distribution Model (NGTDM)

Oil and Gas Supply Module (OGSM)

Petroleum Market Module (PMM)

Renewable Fuels Module (RFM)

Residential Sector Demand Module (RSDM)

Transportation Sector Demand Module (TRAN)

WORLD Reference Model (WOR)

\section{Revenue Requirements Modeling System (RRMS)}

Revenue Requirements Model

Single Asset Model 

Appendix B

AEO 95 Forecasting

System 



\section{Appendix B}

\section{AEO95 Forecasting System}

The Annual Energy Outlook 1995 (AEO95) presents the midterm energy forecasts of the Energy Information Administration (EIA). This year's report presents projections and analyses of energy supply, demand, and prices through 2010, based on results from the National Energy Modeling System (NEMS). Quarterly forecasts of energy supply and demand for 1995 and 1996 are published in the Short-Term Energy Outlook (February 1995).

Forecast tables for the five cases examined in the AEO95 are provided in Appendixes A through C. Appendix A gives historical data and forecasts for selected years from 1992 through 2010 for the reference case. Appendix B presents two additional cases, which assume higher and lower economic growth than the reference case. Appendix $\mathrm{C}$ presents two cases that assume higher and lower world oil prices.

Appendix D presents a summary of the forecasts in units of oil equivalence. Appendix E presents a summary of household energy expenditures. Appendix $\mathrm{F}$ provides detailed comparisons of the $A E O 95$ forecasts with those of other organizations. Appendix $\mathrm{G}$ briefly describes NEMS and the major AEO 95 forecast assumptions. Appendix $\mathrm{H}$ presents a stand-alone high electricity demand case. Appendix I provides a table of energy conversion factors and a table of metric conversion factors.

The $A E O 95$ projections are based on Federal, State, and local laws and regulations in effect on August 15, 1994. They include the fuel taxes in the Omnibus Budget Reconciliation Act of 1993, the Clean Air Act Amendments of 1990, the Energy Policy Act of 1992, and the provisions of the Climate Change Action Plan. Pending legislation and sections of existing legislation for which funds have not been appropriated are not reflected in the forecasts.

Carbon emissions projections in AEO95 were calculated using carbon coefficients from the report, Emissions of Greenhouse Gases in the United States 1987 - 1992, published in October 1994. The coefficients are revised from those used AEO94, which were based on the previous report, Emissions of Greenhouse Gases in the United States 1985 - 1990, published in September 1993.

The $A E O 95$ definition of petroleum product imports incorporates imports of unfinished oils, alcohols, ethers, and blending components, which were not included in the $A E O 94$ definition. The definition was modified so that import dependency projections would align more closely with the historical series in the Annual Energy Review and with the product import definition in the Short-Term Energy Outlook. As a result, the projection of the percentage of U.S. petroleum consumption met by imports is higher in 2010 by 2.7 percent than it would have been with the $A E O 94$ definition.

The $A E O 95$ projections are used by Federal, State, and local governments, trade associations, and other planners and decisionmakers in the public and private sectors. They are published in accordance with Section 205(c) of the Department of Energy Organization Act of 1977 (Public Law 95-91), which requires the Administrator of EIA to prepare an annual report that contains trends and projections of energy consumption and supply. 


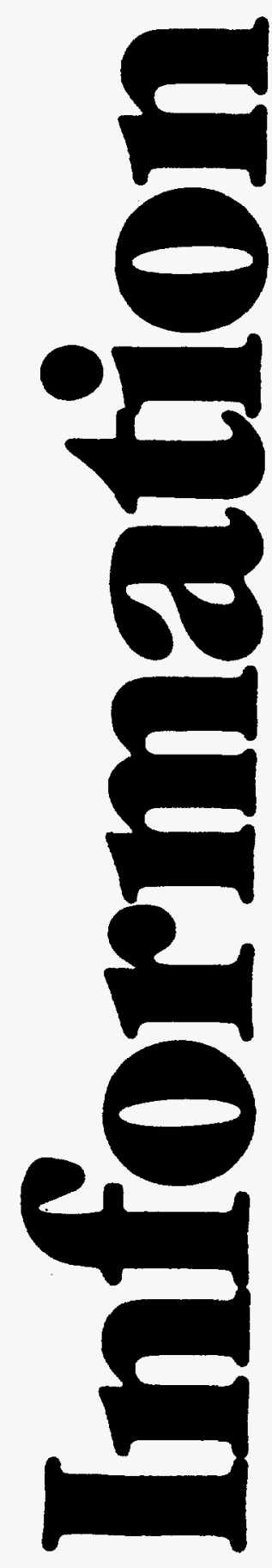
Information from the Federal Govern- ment on subjects ranging from agricul- ture to zoology is available at Depository Libraries across the nation.

You can visit these

libraries and use the Depository collections without charge.

To find one in your area, contact your local library or write: Federal Depository Library Program, Office of the Public Printer, Washington, DC 20401.

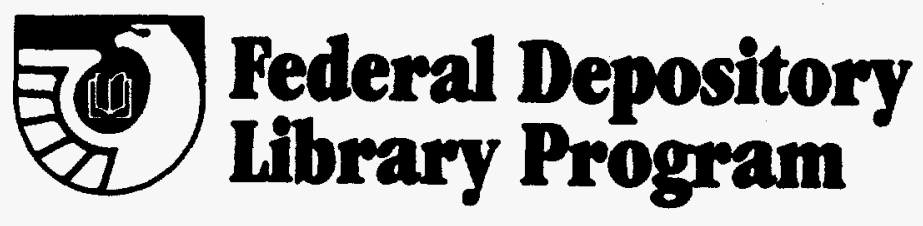

